https://doi.org/10.11646/phytotaxa.362.2.1

\title{
The genus Lepidaploa (Vernonieae, Asteraceae) in southern South America
}

\author{
DANILO MARQUES ${ }^{1}$, GABRIELA ELIZABETH FARCO², JIMI NAOKI NAKAJIMA ${ }^{3} \&$ MASSIMILIANO \\ DEMATTEIS ${ }^{4}$ \\ ${ }^{I}$ Instituto de Botánica del Nordeste (UNNE-CONICET), Casilla de Correo 209, CP 3400 Corrientes, Argentina. \\ E-mail:danilobioufu@gmail.com \\ ${ }^{2}$ Instituto de Botánica del Nordeste (UNNE-CONICET), Casilla de Correo 209, CP 3400 Corrientes, Argentina. \\ E-mail: gabyfarco@hotmail.com \\ ${ }^{3}$ Universidade Federal de Uberlândia, Instituto de Biologia, Programa de Pós-graduação em Biologia Vegetal, Campus Umuarama, \\ Bloco 2D, 38.400-902 Uberlândia, Minas Gerais, Brasil.E-mail: nakajima@ufu.br \\ ${ }^{4}$ Instituto de Botánica del Nordeste (UNNE-CONICET), Casilla de Correo 209, CP 3400 Corrientes, Argentina. \\ E-mail:mdematteis@agr.unne.edu.ar
}

\begin{abstract}
A morphological analysis of the genus Lepidaploa (Vernonieae) of southern South America has been carried out. Until now, the information concerning the genus was fragmented and incomplete for this region. Altogether, 13 species are described and illustrated here. A comprehensive key to the species of southern South America is presented; in addition, we characterized and delimited the distributions of the species.
\end{abstract}

Key words: South America, Compositae, flora, taxonomic treatment

\section{Introduction}

Asteraceae is one of the most important and representative Angiosperm families in the world, covering 24,000 species (Funk et al. 2009). The family inhabits temperate, tropical, mountainous, dry and open environments (Anderberg et al. 2007). Asteraceae is considered a monophyletic family that presents several morphological and molecular synapomorphies (Funk et al. 2009). Asteraceae comprises 13 subfamilies and 44 tribes (Panero et al. 2014), with Eupatorieae and Vernonieae among the greatest in the number of species (Funk et al. 2009).

The tribe Vernonieae has a pantropical distribution and is composed of 126 genera and 1,500 species, being the fifth tribe in Asteraceae with the highest number of species (Keeley \& Robinson 2009). In a series of studies in Vernonieae, Robinson (1999) substantially altered the traditional circumscription of Vernonia sensu lato, fragmenting it into several genera, as e.g. Lepidaploa Cassini (1817: 66) Cassini (1825: 20).

Currently, Lepidaploa is the largest genus of the tribe and has around 140-150 species (Funk et al. 2009, Angulo et al. 2012). Plants of this genus are characterized by presenting small capitula grouped in cymose inflorescences, commonly eglandular anther apical appendages, basal stylar node present, usually eglandular cypselae and pollen of types C, D or G (Robinson 1990, 1999).

The genus Lepidaploa is distributed from Mexico to northeast of Argentina (Redonda-Martínez \& Villaseñor 2011, Marques \& Dematteis 2014). Brazil is a country with the greatest diversity of its species, 51 in total (Dematteis \& Almeida 2015). This country is followed by Bolivia with 27 species (Hind 2011), and Venezuela and Cuba with 16 species each (Redonda-Martínez \& Villaseñor 2011). In southern South America, Lepidaploa is distributed in Paraguay (Dematteis \& Cabrera 2009), south of Brazil (Dematteis \& Almeida 2015), and north and northeast of Argentina (Marques \& Dematteis 2014). However, the genus occurs neither in Chile (Moreira-Muñoz 2011) nor in Uruguay.

Due to the importance of a taxonomic treatment of the genus Lepidaploa in southern South America, here we present an identification key, descriptions, illustrations and geographical distributions, discussing the affinities between the species. 


\section{Material and Methods}

Southern South America is the area constituted by Argentina, Chile, Paraguay, Uruguay and southern Brazil (Paraná, Santa Catarina and Rio Grande do Sul states) (Zuloaga et al. 2008). The area lies between $48^{\circ}-75^{\circ} \mathrm{N}$ and $17^{\circ} 30^{\prime}-$ $56^{\circ} 30^{\prime} \mathrm{S}$ and comprises about $4,708,617 \mathrm{~km}^{2}$, representing about $26 \%$ of the entire territory of South America (Zuloaga et al. 2008). This area has a great variety of biogeographic regions with peculiar characteristics, which causes a great floristic diversity (Zuloaga et al. 2008). In total, 11 biogeographic regions are included in southern South America: North-Central Humid Andes, South-Central Dry Andes, Atlantic Forest, Cerrado, Chilean-Peruvian Desert, Chile Mediterranean, Chaco, Pampas, Monte, Patagonia and Pacific Temperate Humid (Zuloaga et al. 2008). Among these biogeographic regions, five are included within hotspots: North-Central Humid Andes, South-Central Dry Andes, Mediterranean Chile, Cerrado and Atlantic Forest (Myers et al. 2000; Newtow \& Tejedor 2011).

Southern South America has a great number of species (both native and introduced), with 17,693 species grouped in 2,586 genera and 308 families (Zuloaga et al. 2008). A total of 249 genera are endemic to southern South America. Regarding species, 7,691 are endemic to southern South America, representing $43.47 \%$ of the total species diversity in the area (Zuloaga et al. 2008). In this region, the family with the highest number of endemic representatives is Asteraceae (Zuloaga et al. 2008).

The study of the species was made based on material from the following herbaria: CTES, FCQ, FLOR, FURB, HBR, ICN, MBM, MVFA, PACA, RB and SCP. Only one herborized specimen of each province or state, in which the species occur, is listed as selected specimens examined. For the examined material the location, date, collector(s) and collector number(s) are cited. In addition, all the material examined in this work is included in a list of collectors. When the material from the area could not be consulted in the herbarium, as happened for example with $L$. decumbens, material from other states was used for the species description. For the habitat (biogeographic region), the terminology used was based in Zuloaga et al. (2008). For each species are mentioned the provinces or states of occurrence of plants both inside and outside southern South America. The distribution map was made in QGIS version 2.18.9 with GRASS 2.2.1. The terminology used in descriptions follows Radford (1986) and Dematteis \& Cabrera (2009). The collectors list can be found in Appendix I.

\section{Taxonomic treatment}

Lepidaploa includes 13 species occurring in southern South America, of which two are endemic to the area (L. novarae and $L$. pseudomuricata). However, most of the species described in this study are endemic to South America, except L. remotiflora and L. salzmannii which are distributed from Mexico to Argentina (Redonda-Martínez \& Villaseñor 2011). In terms of distribution, L. argyrotricha occurs exclusively in Brazil (Dematteis \& Almeida 2015), while $L$. eriolepis grows in Brazil and Bolivia (Hind 2011; Dematteis \& Almeida 2015). Lepidaploa amambaia is restricted to Paraguay and Mato Grosso do Sul in Brazil (Dematteis \& Cabrera 2009, Dematteis \& Almeida 2015). On the other hand, L. balansae occurs in Argentina, Paraguay and in the southern states and in the state of São Paulo in Brazil (Dematteis \& Cabrera 2009, Marques \& Dematteis 2014, Dematteis \& Almeida 2015). Lepidaploa chamissonis and L. psilostachya occur exclusively in Argentina and Brazil (Marques \& Dematteis 2014, Dematteis \& Almeida 2015), while L. setososquamosa is distributed in Argentina, Bolivia and Paraguay (Dematteis \& Cabrera 2009, Hind 2011, Marques \& Dematteis 2014). Most of these species are present in biodiversity hotspots (Cerrado, Atlantic Forest or North-Central Humid Andes).

The species of Lepidaploa in southern South America are restricted to Argentina, Paraguay and southern Brazil. Although in Argentina the genus is distributed in the north and northeast, Lepidaploa is not found in Chile and Uruguay, probably due to climatic differences. Among geopolitical regions, southern Brazil is the area of southern South America that presented the largest number of species. In total, nine species of Lepidaploa were found in this Brazilian region. Argentina is the second country in southern South America with the highest number of species of Lepidaploa (eight species), followed by Paraguay that has four or five species, considering that $L$. salzmannii also occurs in Paraguay as reported by Dematteis \& Cabrera (2009). 
Lepidaploa (Cassini) Cassini (1825: 20). Vernonia subgen. Lepidaploa Cassini (1817: 66).

Type (designated by Robinson et al. (1980: 428)): Vernonia albicaulis Persoon [= Lepidaploa glabra (Willdenow) H. Rob.]

Herbs, subshrubs or erect shrubs, rarely clambering (L. balansae, L. novarae and L. tarijensis). Branches strigose, strigosetomentose, pubescent, sericeous, setose or velutinous. Leaves distichous, rarely spirally alternate (L. pseudomuricata), cauline or rarely basal and cauline (L. psilostachya), petiolate or sessile; blade membranous, chartaceous, membranouscoriaceous, smooth or rugose, elliptic, elliptic-lanceolate, lanceolate, linear-lanceolate, oblong-lanceolate, ovallanceolate, oval, ovate-lanceolate, apex apiculate, acute, caudate, margins entire or denticulate, rarely serrulate, sinuate or revolute (L. balansae, L. decumbens and L. psilostachya), base attenuate, cuneate, adaxial surface strigose, strigosetomentose, glabrous, pubescent, abaxial surface strigose, glabrous, incanous, pubescent, tomentose, velutinous, venation brochidodromous, camptodromous, camptodromous-eucamptodromous, eucamptodromous, eucamptodromousbrochidodromous, eucamptodromous-reticulodromous. Capitulescence seriate-cymose with capitula sessile, rarely paniculiform; axis strigose-tomentose, glabrous or glabrescent, tomentose-velutinous, velutinous, villous, whitish, gold, ferruginous, gray, brown, green or yellowish-green. Involucre campanulate, rarely turbinate ( $L$. balansae); phyllaries 4-6-seriate, yellowish, chestnut, brown, reddish, greenish, greenish with blackened apex, scarious, membranaceous, strigose, strigose-tomentose, glabrous, pubescente, tomentose, villous; outer elliptic-lanceolate, linear-lanceolate, ovate, oval-lanceolate, apex apiculate, rarely aristate (L. setososquamosa) or apiculate-recurved (L. decumbens); inner elliptic-lanceolate, lanceolate, apex acute, acute-apiculate, apiculate, rarely aristate ( L. setososquamosa) or apiculaterecurved ( $L$. decumbens), obtuse to rotund. Florets 10-40, corolla white, lilac, pink, violet, tube glabrous, lobes lanceolate, apex glandular, setose or setose-glandular; apical anther appendages acute, obovate or obtuse, rarely with glandular trichomes (L. pseudomuricata), base obtuse or sagittate; basal stylar node enlarged, rarely narrow (L. balansae and L. pseudomuricata). Cypsela turbinate, obconic, velutinous, setose, sericeous-glandular (L. setososquamosa); carpopodium annular, idioblasts lacking or present. Pappus 2-seriate, white or beige, rarely grayish, brown or chestnut (L. novarae, L. balansae and L. eriolepis).

\section{Key to species of Lepidaploa of southern South America}

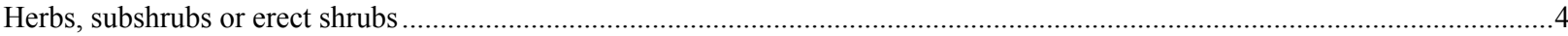

2. Venation brochidodromous; pappus brown; heads with 10-12 florets; involucre turbinate; basal stylar node narrow; species widely

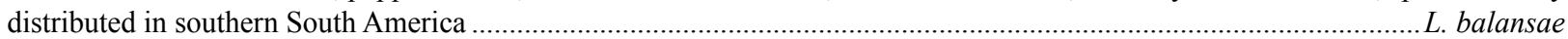
Venation camptodromous-eucamptodromous; pappus whitish; heads with 20-27 florets; involucre campanulate; basal stylar node enlarged; species restricted to the province of Salta. Involucre 6-7 mm in diam.; glandular trichomes present on corolla lobes; cypselae with idioblasts ........................... L. novarae Involucre 8-10 mm in diam.; glandular trichomes absent on corolla lobes; cypselae without idioblasts ......................L. tarijensis Branches prominently ribbed; anther appendages with glandular trichomes; basal stylar node narrow ...............L. pseudomuricata Branches not ribbed or slightly ribbed; anther appendages without glandular trichomes; basal stylar node enlarged......................5 Heads with 35-40 florets; branches, inflorescences, leaves and phyllaries strigose-tomentose; pappus nut-brown........ L. eriolepis Heads with 15-25 florets; branches, inflorescences, leaves and phyllaries glabrescent, pubescent, setulose, strigose, tomentose, velutinous or villous; pappus white or beige

6. Leaf margins entire. ...6

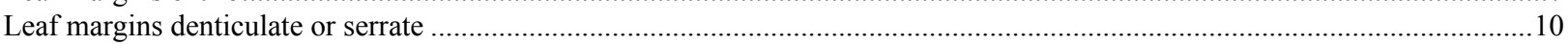
Leaves with petiole 13.5-14 mm long; corolla lobes without glandular trichomes............................................. L. argyrotricha Leaves with petiole $0.3-7 \mathrm{~mm}$ long or sessile; corolla lobes with glandular trichomes ..................................................... Leaf blade ovate, oval-lanceolate, ovate-lanceolate; leaves with petioles $3-7 \mathrm{~mm}$ long.........................................L. chamissonis

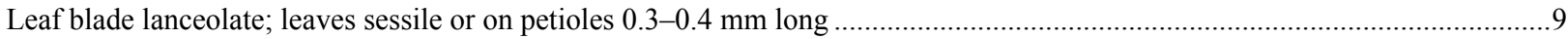
Leaf margins revolute, adaxial surface strigose; inflorescence $1.6-3.6 \mathrm{~cm}$ long; phyllaries with apex apiculate-recurved.

L. decumbens

Leaf margins plane, adaxial surface tomentose; inflorescence 12-13.2 cm long; phyllaries with apex apiculate-recurved......

10. Leaves basal and cauline; venation camptodromous............................................................................... L. psilostachya Leaves only cauline; venation eucamptodromous-brochidodromous or eucamptodromous-reticulodromous..............................11

11. Leaf apex acute, venation eucamptodromous-reticulodromous; inner phyllaries with apex acute; glandular trichomes present on corolla lobes and style branches .................................................................................................................. L. remotiflora Leaf apex apiculate, venation eucamptodromous-brochidodromous; inner phyllaries with apex apiculate or aristate; glandular

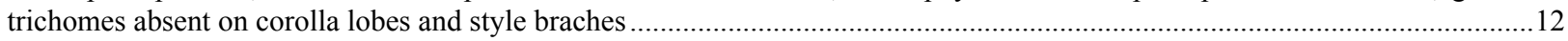

12. Leaves with petiole $1.5-2.6 \mathrm{~mm}$ long; heads with $17-18$ florets; involucre 8-10 $\mathrm{mm}$ long; cypselae velutinous.........L. amambaia

- $\quad$ Leaves sessile; heads with 23-25 florets; involucre 12-14 mm long; cypselae sericeous-glandular .................. L. setososquamosa 


\section{Lepidaploa amambaia Robinson (1998: 40).}

Type:-BRAZIL. Mato Grosso do Sul state, Rod. MT 642, “20 km de Amambai', 16 December 1983, G. Hatschbach \& L. Callejas 47289 (holotype MBM! [photo!]; isotype US! [photo!]). Figure 1

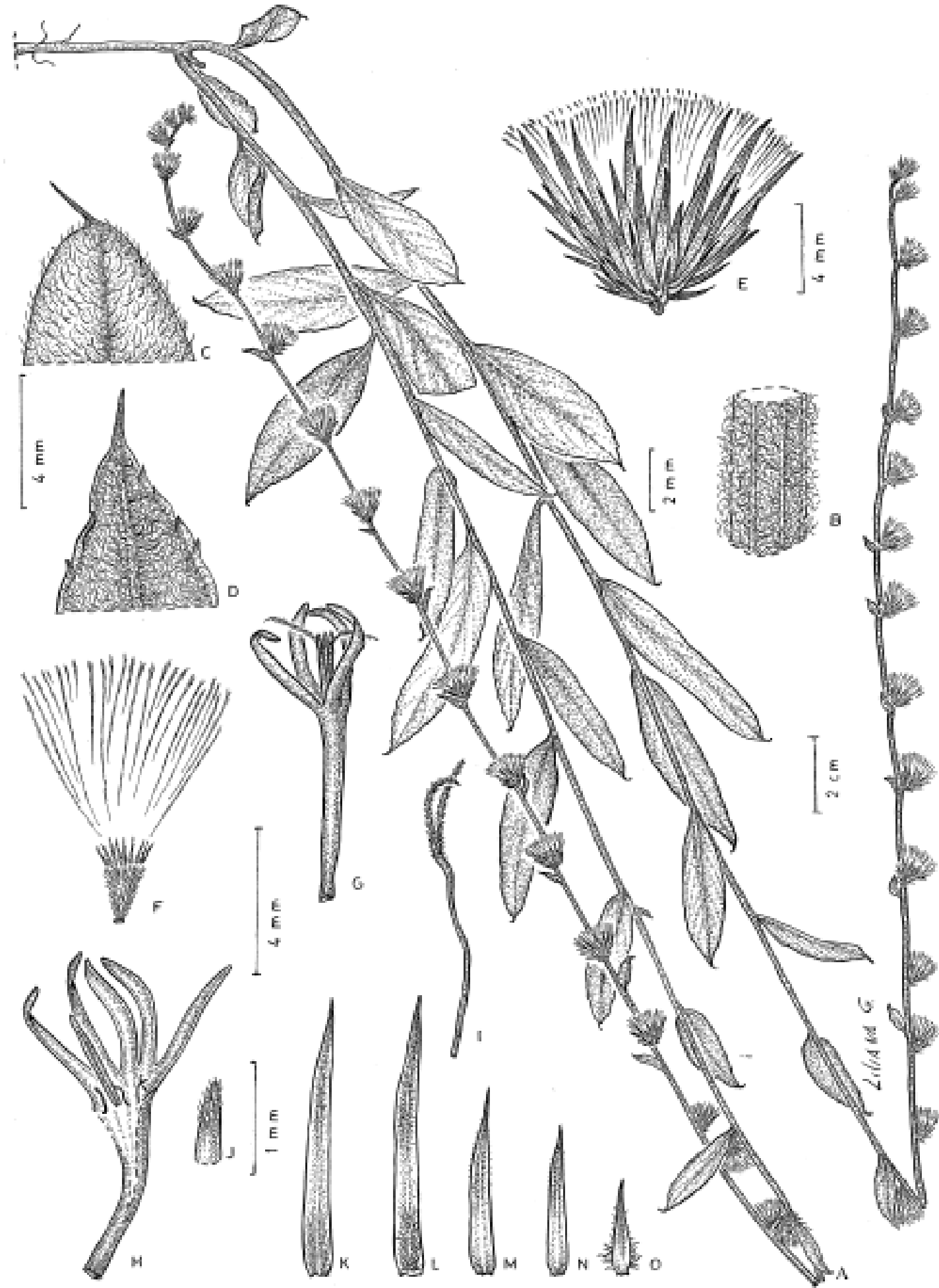

FIGURE 1. Lepidaploa amambaia. A. Plant. B. Stem detail. C. Abaxial leaf surface detail. D. Abaxial leaf surface detail. E. Capitula. F. Cypsela and pappus. G. Floret. H. Floret dissected with anther detail. I. Style. J. Corolla lobe detail. K-M. Inner phyllaries. N-O. Outer phyllaries.

Herbs or erect subshrubs $0.4-0.7 \mathrm{~m}$ tall; branches strigose-tomentose, slightly ribbed. Leaves distichous, cauline, internodes 2.4-2.8 cm long, petioles 1.5-2.6 mm long; blade 3.5-5.3 $\times 0.7-1.9 \mathrm{~cm}$, chartaceous, smooth, ovatelanceolate or elliptic-lanceolate, apex largely apiculate, margins denticulate, base attenuate to cuneate, both surfaces strigose; venation eucamptodromous-brochidodromous. Capitulescence seriate-cymose with capitula sessile, 8.3- 
$17.4 \mathrm{~cm}$ long, axis strigose-tomentose, green or whitish. Involucre largely campanulate, $8-10 \mathrm{~mm}$ in diam., phyllaries 5-6-seriate, chestnut, greenish, membranaceous, strigose, outer elliptic-lanceolate, apex apiculate, inner lanceolate, apex apiculate. Florets 17-18, corolla violet, tube 4-6 mm long, glabrous, lobes $2.5-3 \mathrm{~mm}$ long, lanceolate, apex setose; apical anther appendages obtuse, base obtuse; basal stylar node enlarged. Cypsela turbinate to obconic, 1.5-2 mm long, velutinous; carpopodium annular. Pappus white.

Selected specimens examined —PARAGUAY. Amambay: $25 \mathrm{~km} \mathrm{~N}$ of J. P. Caballero, 10 December 1997, M. Dematteis \& A. Schinini 867 (CTES). Caaguazú: Fazenda La Esmeralda, 11 December 1982, A. Schinini s.n. (CTES 22903). Central: Limpio, 13 March 1985, E. Bordas 3674 (CTES). Concepción: 25 km of San Carlos from Apa, Estancia Arrecifes, 06 March 2009, M. Dematteis 3336 (CTES, FCQ).

Distribution and habitat - In southern South America this species occurs only in the departments Amambay, Caaguazú, Central and Concepción in Paraguay. According to Dematteis \& Cabrera (2009), L. amambaia also occurs in the department Canindeyú, Paraguay. It was found on fields of Cerrado (Figure 2).

Phenology - Collected with flowers and fruits between December and March.

Notes - It is similar to L. psilostachya, L. remotiflora and L. setososquamosa which also occur in southern South America. Lepidaploa amambaia can de differentiated from L. psilostachya by its usually greater size, 0.4-0.7 (versus 0.3-0.45) $\mathrm{m}$ tall, leaves present only on the stem (versus at the base and on the stem), leaf apex long apiculate (versus acute) and venation eucamptodromous-brochidodromous (versus camptodromous). In turn, L. amambaia differs from L. remotiflora by the apiculate (versus acute) apex of its leaves, a smaller (17-18 versus 21-23) number of florets and the absence (versus presence) of glandular trichomes on the style branches and corolla lobes. Finally, L. amambaia is distinguished from L. setososquamosa by 17-18 (versus 23-25) florets per head, involucre 8-10 (versus 14-15) $\mathrm{mm}$ long, petiolate leaves (versus sessile) and velutinous cypselae (versus sericeous-glandular).

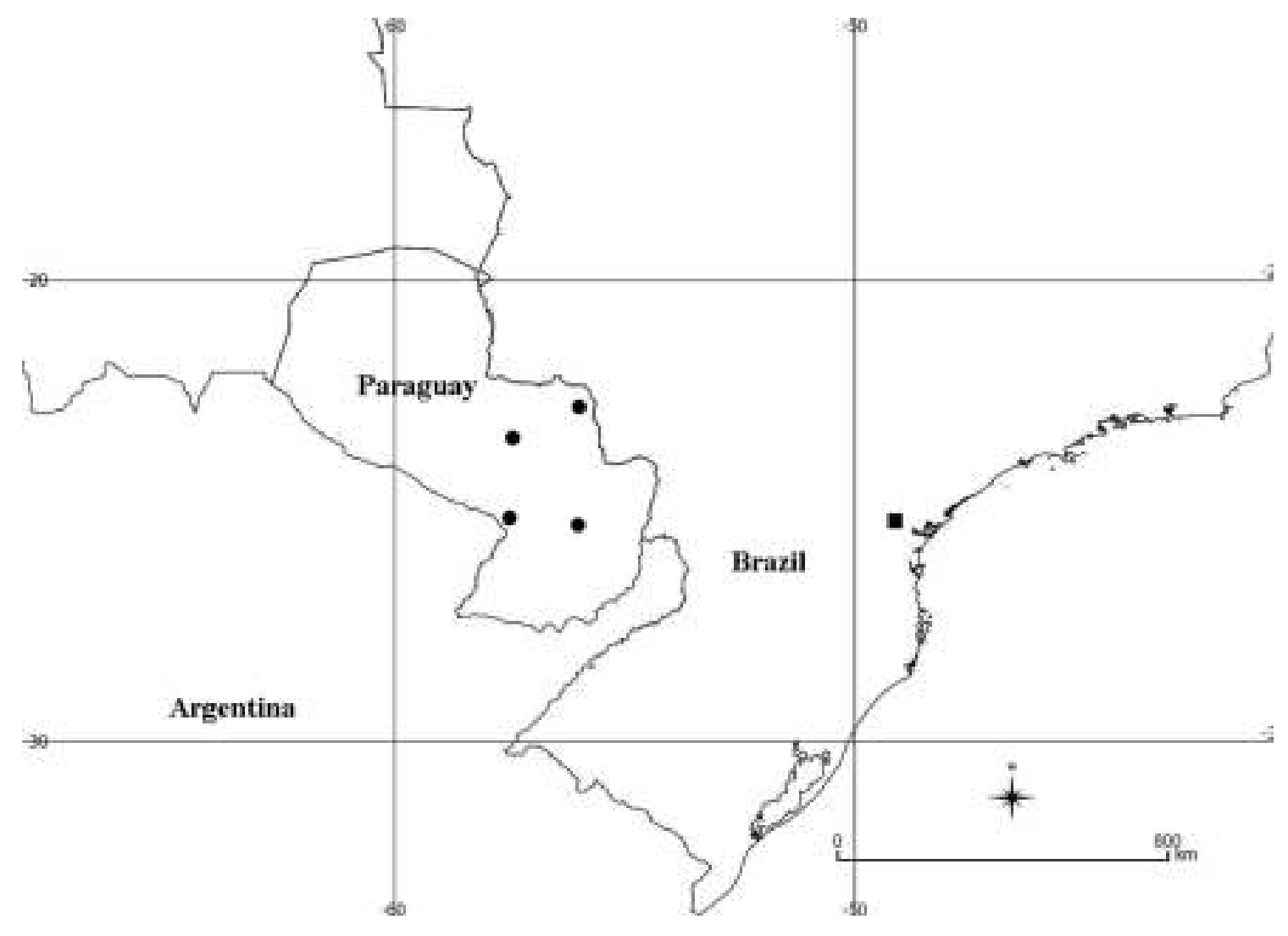

FIGURE 2. Geographical distribution of L. amambaia (circle) and L. argyrotricha (square) in Cone Sur. 
2. Lepidaploa argyrotricha (Sch. Bip. ex Baker) Robinson (1990: 482). Vernonia argyrotricha Sch. Bip. ex Baker (1873: 96).

Type:-BRAZIL. Without locality, F. Sello 1153 (syntype P! [online image!]). Figure 3.

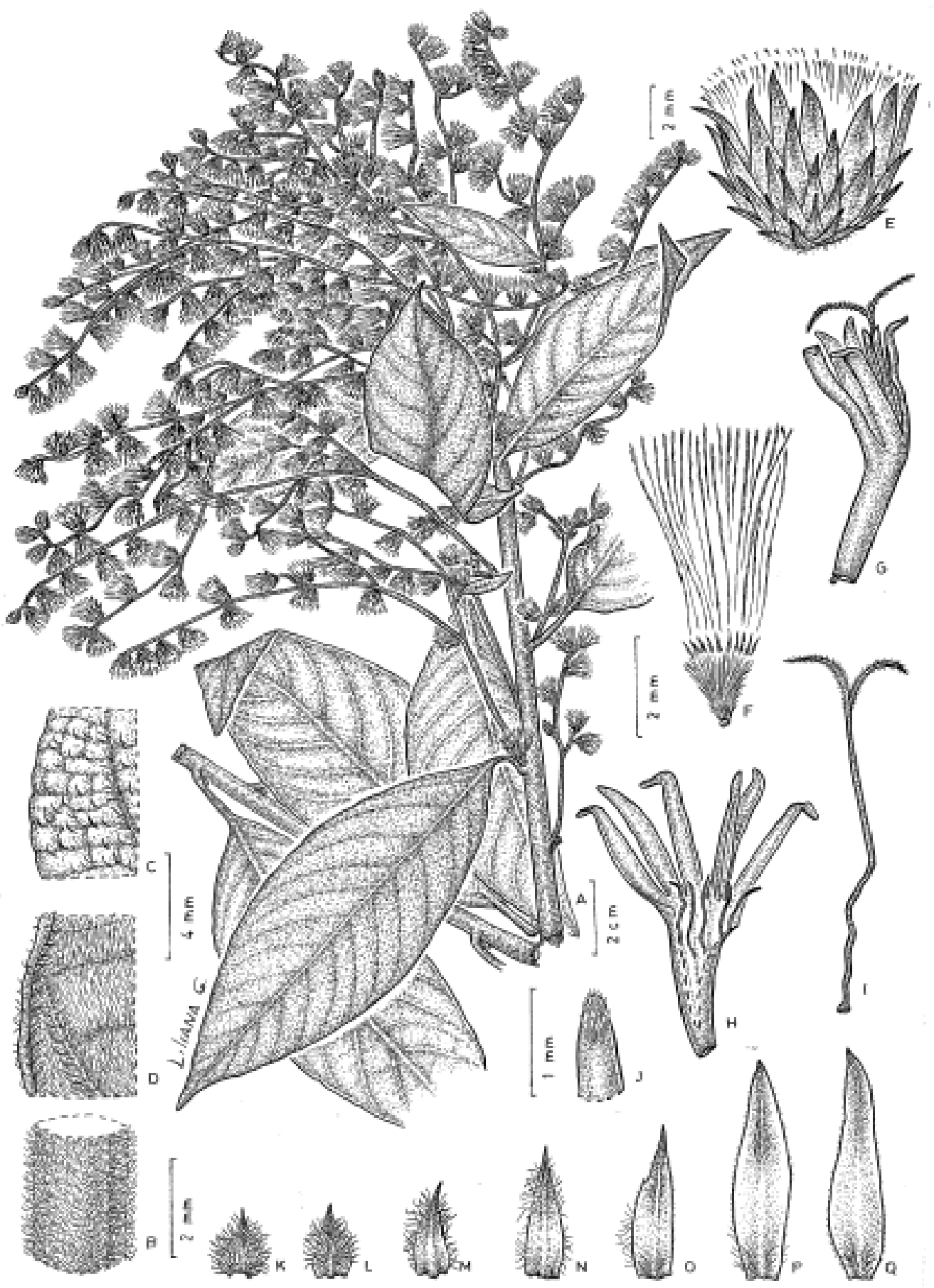

FIGURE 3. Lepidaploa argyrotricha. A. Plant. B. Stem detail. C. Abaxial leaf surface detail. D. Abaxial leaf surface detail. E. Capitula. F. Cypsela and pappus. G. Floret. H. Floret dissected with anther detail. I. Style. J. Corolla lobe detail. K-M. Outer phyllaries. N-Q. Inner phyllaries.

Erect subshrubs $0.9 \mathrm{~m}$ tall; branches velutinous. Leaves distichous, cauline, internodes $1.5-1.6 \mathrm{~cm}$ long, petioles $13.5-$ $14 \mathrm{~mm}$ long; blade 13.55-14.6 $\times 4.1-4.7 \mathrm{~cm}$, membranaceous-coriaceous, rugose, elliptic to lanceolate, apex acute to caudate, margins entire, base cuneate, adaxial surface strigose, abaxial surface velutinous; venation eucamptodromous. Capitulescence seriate-cymose with capitula sessile, $12,7 \mathrm{~cm}$ long, axis densely velutinous, golden. Involucre narrowly campanulate, 6-8 $\mathrm{mm}$ in diam., phyllaries 5-6-seriate, brown or reddish, membranaceous, villous, outer oval-lanceolate, apex apiculate, intter elliptic-lanceolate, apex apiculate. Florets 18-19, corolla lilac, tube 3.2-4 mm 
long, glabrous, lobes 2-2.5 mm long, lanceolate, apex setose; apical anther appendages obovate, base sagittate; basal stylar node enlarged. Cypsela turbinate to obconic, $1.55-1.7 \mathrm{~mm}$ long, setose; carpopodium annular. Pappus white.

Selected specimens examined-BRASIL. Paraná: Bocaiúva do Sul, Estancia Sesmaria, roadside, 27 January 2005, E. Barbosa 1012 (CTES, MBM).

Distribution and habitat - The species is very rare in southern South America. It was found only in one locality in the state of Paraná in Brazil. It was collected in the Atlantic Rainforest (Figure 2).

Phenology - Collected with flowers and fruits between December and March.

Notes - The species may be confused with $L$. chamissonis because of its whitish indumentum on the abaxial leaf surface. However, L. argyrotricha has blade leaves 13.5-14.6 × 4.1-4.7 cm (versus $2.7-9.8 \times 1.8-3.9 \mathrm{~cm}$ ), petiole 13.5-14 mm (versus 5-7 mm) long and corolla lobes without glandular trichomes (versus with glandular trichomes). In addition, $L$. argyrotricha has a very restricted distribution while $L$. chamissonis has a broader distribution in southern South America.

3. Lepidaploa balansae (Hieron.) Robinson (1994: 27). Vernonia balansae Hieronymus (1897: 690). Type:-PARAGUAY. Guarapí, 1 August 1881, B. Balansa 3060 (syntypes G! CORD!, K! [online image!]). Figure 4.

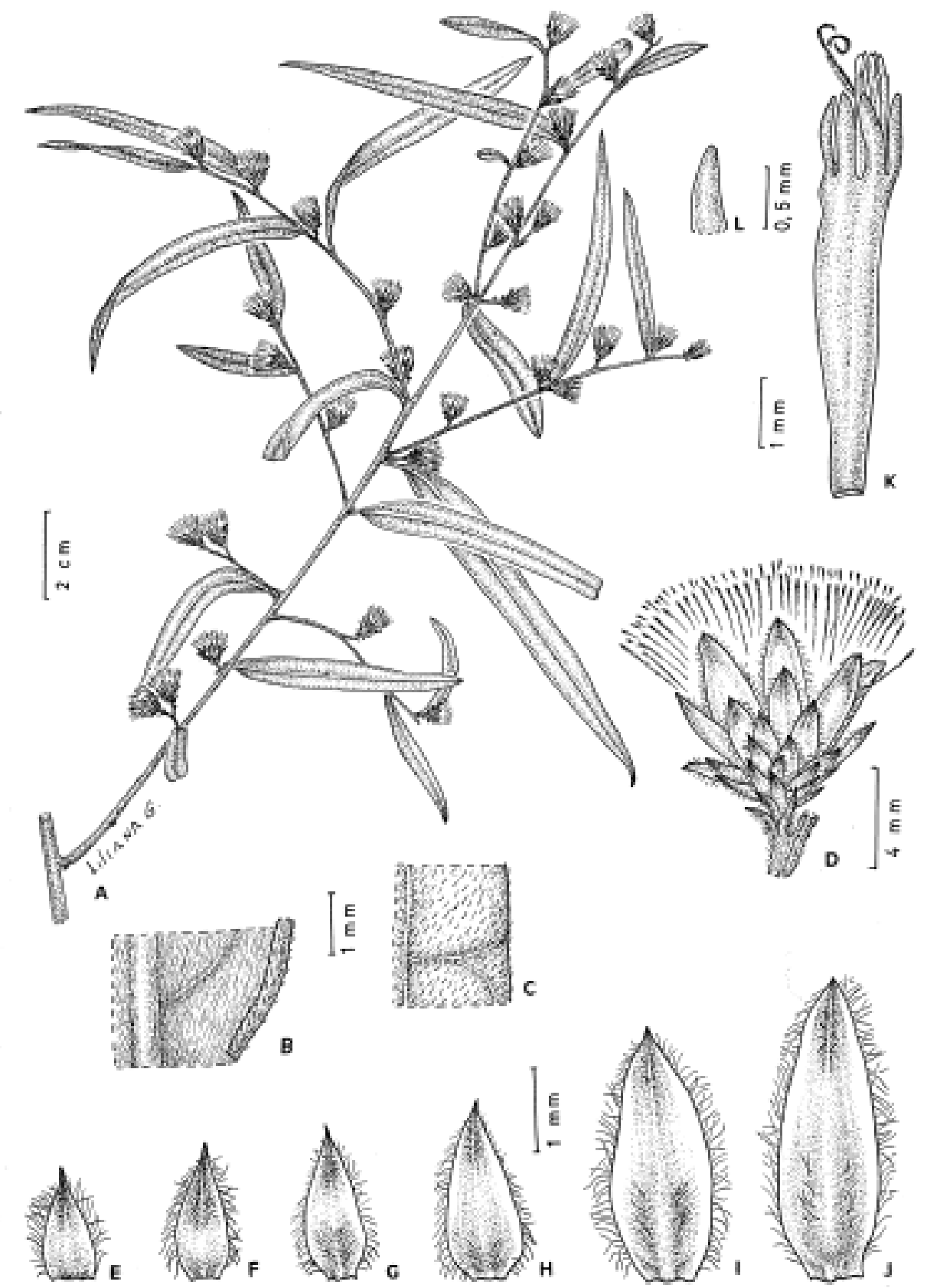

FIGURE 4. Lepidaploa balansae. A. Plant. B-C. Leaf detail. D. Capitula. E-G. Outer phyllaries. H-J. Inner phyllaries. K. Floret. L. Corolla lobe detail. Source: Marques \& Dematteis (2014). 
Clambering shrubs $0.5-3 \mathrm{~m}$ tall; branches pubescent. Leaves distichous, cauline, internodes 1.2-2.6 cm long, petioles $0.28-0.35 \mathrm{~mm}$ long, blade $4.4-14.9 \times 0.2-2.9 \mathrm{~cm}$, membranaceous to cartaceous, smooth, lanceolate to linear-lanceolate, apex acute, margins entire, revolute, base attenuate, adaxial surface glabrous, abaxial surface incanous; venations brochidodromous. Capitulescence seriate-cymose with capitula sessile $6.2-8 \mathrm{~cm}$ long, axis glabrous or glabrescent, brown. Involucre turbinate, $6-7 \mathrm{~mm}$ in diam., phyllaries 5-6-seriate, brown to greenish, membranaceous, pubescent, outer ovate, apex apiculate, inner elliptic-lanceolate, apex obtuse to rotund. Florets 10-12, corolla lilac, white, tube 4.5-5 mm long, glabrous, lobes 1.2-2 mm long, lanceolate, apex setose-glandular; apical anther appendages obtuse, base sagittate; basal stylar node narrow. Cypsela turbinate, 1-1.2 mm long, setose; carpopodium anullar. Pappus brown.

Selected specimens examined-ARGENTINA. Corrientes: Departamento Santo Tomé, Arroyo Chimiray, 23 September 1974, M. Krapovickas 26236 (CTES). Misiones: Departamento Guaraní, Predio Guaraní, Rute 15, 8 September 1994, A. Schinini 28740 (CTES). BRASIL. Paraná: Município de Campo Mourão, Parque do Lago, 28 July 2004, M.G. Caxambú 518 (MBM). Santa Catarina: Município de São Miguel d'Oeste, Paraíso, Peperi, 1 September 1964, R.M. Klein 5726 (HBR). Rio Grande do Sul: Departamento Gaurama, estrada secundária em direção a BR 153, 24 August 1996, J.A. Jarenkow 3119 (MBM). PARAGUAY. Alto Paraná: Distrito Alto Vera, Cordillera San Rafael, 14 December 2001, F. González 256 (FCQ). Caazapá: Departamento Mbaracayú, Comunidad Mbyá, 1 July 1989, I. Basualdo 2544 (CTES, FCQ). Canindeyú: Rumbo Norte, 20 August 1996, B. Jiménez 1408 (CTES). Concepción: Estancia San Fernando, Potrero Mamorei, 09 July 1991, I. Basualdo 3500 (FCQ). Guairá: Cordillera Ybytyruzú, Ruta Cantera Jhú, 8 km S de Coronel Oviedo, 16 December 1989, E. Zardini 14967 (FCQ). Itapúa: Estancia Parabel Itapuá, 10 June 1988, S. Kell 1509 (FCQ). Paraguarí: Cerro Palacios, 5 km N de Paraguarí, 26 January 1989, E. Zardini 9801 (FCQ).

Distribution and habitat-The species is widely distributed throughout southern South America. It can be found in Argentina (Misiones and Corrientes), south of Brazil (Paraná, Santa Catarina and Rio Grande do Sul), and Paraguay (Alto Paraná, Caazapá, Canindeyú, Concepción, Guairá, Itapúa and Paraguarí). It can also be found in the following departments of Paraguay: Amambay, Caaguazú, Cordillera and San Pedro (Dematteis \& Cabrera 2009). Lepidaploa balansae grows in the Atlantic Rainflorest, often near waterbodies (Figure 5).

Phenology - Collected with florets and fruits during most part of the year.

Notes - It can be recognized by the clambering habit, incanous abaxial leaf surface, turbinate heads with 10-12 florets, narrow basal stylar node, brown pappus and a wide distribution in southern South America.

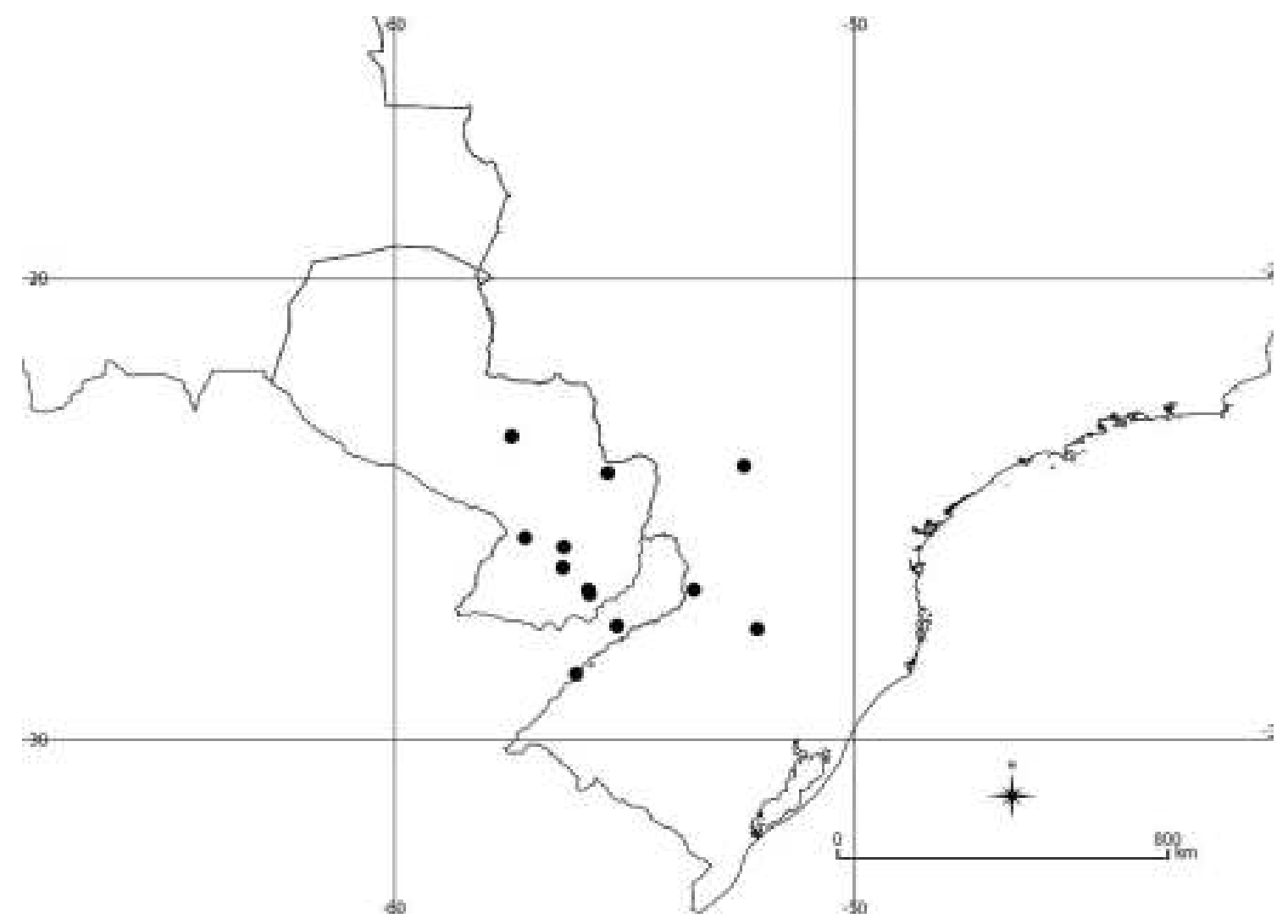

FIGURE 5. Geographical distribution of L. balansae (circle) in Cone Sur. 
4. Lepidaploa chamissonis (Less.) Robinson (1990: 485). Vernonia chamissonis Lessing (1829: 304). Type:-BRAZIL. Without locality, L. A. von Chamisso s.n. (syntype P! [online image!]). Figure 6.

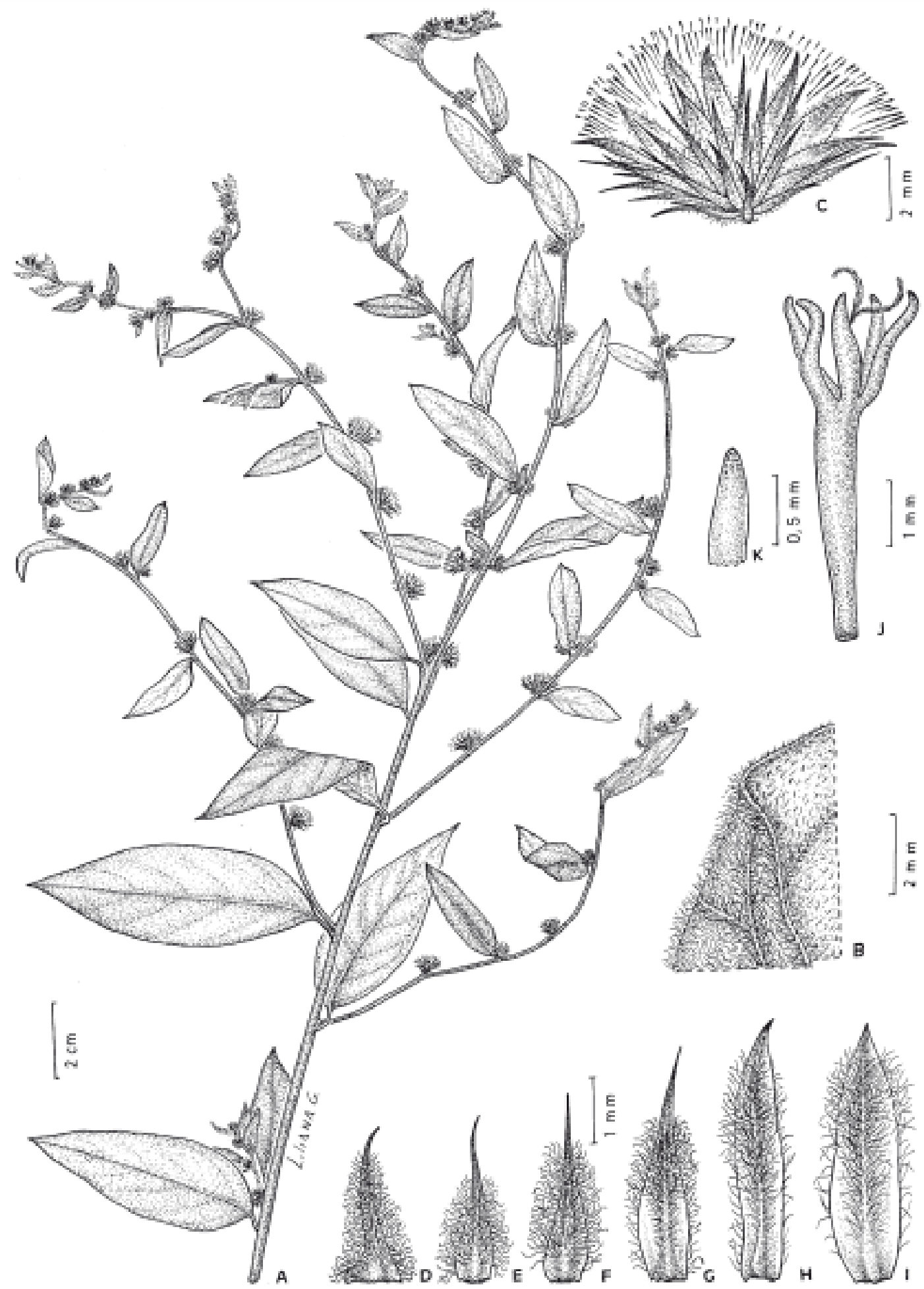

FIGURE 6. Lepidaploa chamissonis. A. Plant. B. Leaf detail. C. Capitula. D-F. Outer phyllaries. G-I. Inner phyllaries. J. Floret. K. Corolla lobe detail. Source: Marques \& Dematteis (2014).

Subshrubs $0.5-1.7 \mathrm{~m}$ tall; branches pubescent. Leaves distichous, cauline, internodes $2.4-3.1 \mathrm{~cm}$ long, petioles 5-7 $\mathrm{mm}$ long, blade 2.7-9.8 × 1.8-3.9 cm, chartaceous to membranaceous, smooth or rugose, oval, oval-lanceolate, ovatelanceolate, apex acute, margins entire, base attenuate, adaxial surface pubescent, abaxial surface velutinous; venation eucamptodromous. Capitulescence seriate-cymose with capitula sessile, 13-24.5 cm long, axis densely velutinous, golden or brown. Involucre campanulate, 5.4-6.2 mm, phyllaries 4-5-seriate, chestnut, scarious, pubescent, outer oval-lanceolate, apex largely apiculate, inner elliptic-lanceolate, apex acute. Florets 20-24, corolla white, pink, tube 
1.9-2.2 mm long, glabrous, lobes 2.1-2.4 mm long, lanceolate, apex setose-glandular; apical anther appendages acute, base obtuse; basal stylar node enlarged. Cypsela turbinate, 1.2-1.34 mm long, setose; carpopodium anullar. Pappus white.

Selected specimens examined-ARGENTINA. Chaco: Departamento Comandante Fernández, $22 \mathrm{~km}$ SE de Campo Largo, 19 February 1980, A. Schinini 19999 (CTES). Corrientes: Corrientes Capital, Costa del Río Paraná, 08 July 1978, A. Schinini 15251 (CTES). Formosa: Bartolomé de las Casas, 08 May 1969, A. Schinini 16950 (CTES). BRASIL. Paraná: Tomazina, Corredeira, Rio das Cinzas, 24 November 1987, G. Hatschbach 51930 (MBM). Santa Catarina: Florianópolis, Bairro Vargem do Bom Jesus, Rua: Servidão Marcelino Antônio Nunes, 13 March 2010, $A$. Stival-Santos 2022 (FURB). PARAGUAY. Paraguarí: Parque Nacional Ibycui, sin fecha, G. Schmeda 55 (CTES). Presidente Hayes: Ruta Trans-Chaco, río Lindo Monte, 14 March 1979, A. Schinini 16585 (CTES).

Distribution and habitat - In the study region the species is distributed in Argentina, Brazil and Paraguay. In Argentina it is restricted to the provinces of Chaco, Corrientes and Formosa; and in southern Brazil the species is found in Paraná and Santa Catarina, but can also be found in Minas Gerais and São Paulo. In Paraguay, L. chamissonis was collected in the provinces of Paraguarí and Presidente Hayes. The species occurs on fields, in the Atlantic Rainforest and the Cerrado (Figure 7).

Phenology - The species is flowering from October to May.

Notes-This species can be confused with $L$. salzmannii and $L$. argyrotrycha, since the three species have a whitish indumentum on the abaxial leaf surface. However, L. argyrotricha is the only species among the three that has a long petiole (13.5-14 $\mathrm{mm}$ ) and glandular trichomes absent in the corolla lobe. Lepidaploa chamissonis differs from $L$. salzmannii by its ovate, oval-lanceolate, ovate-lanceolate leaves and setose cypselae without idioblasts, while L. salzmannii has lanceolate leaves and setose-glandular cypselae with idioblasts. In addition, L. chamissonis is more widely distributed in southern South America, while L. salzmannii is restricted to the states of Paraná and Santa Catarina in Brazil.

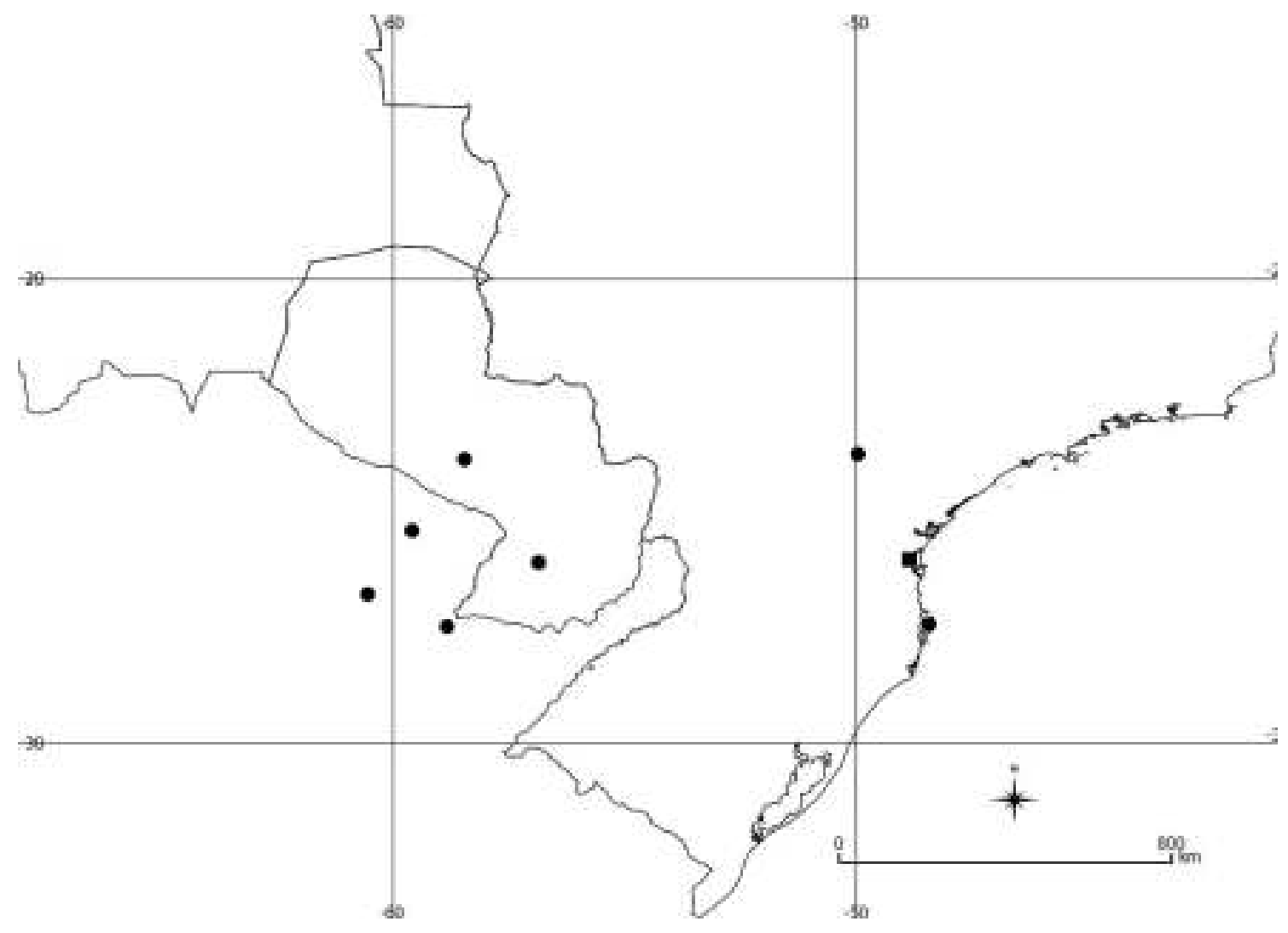

FIGURE 7. Geographical distribution of L. chamissonis (circle) and L. decumbens (square) in Cone Sur. 
5. Lepidaploa decumbens (Gardner) Robinson (1990: 486). Vernonia decumbens Gardner (1845: 115). Type:-BRAZIL. Without locality, G. Gardner 517 (syntypes B! E! F! G! K! NY! P! [online image!]). Figure 8.

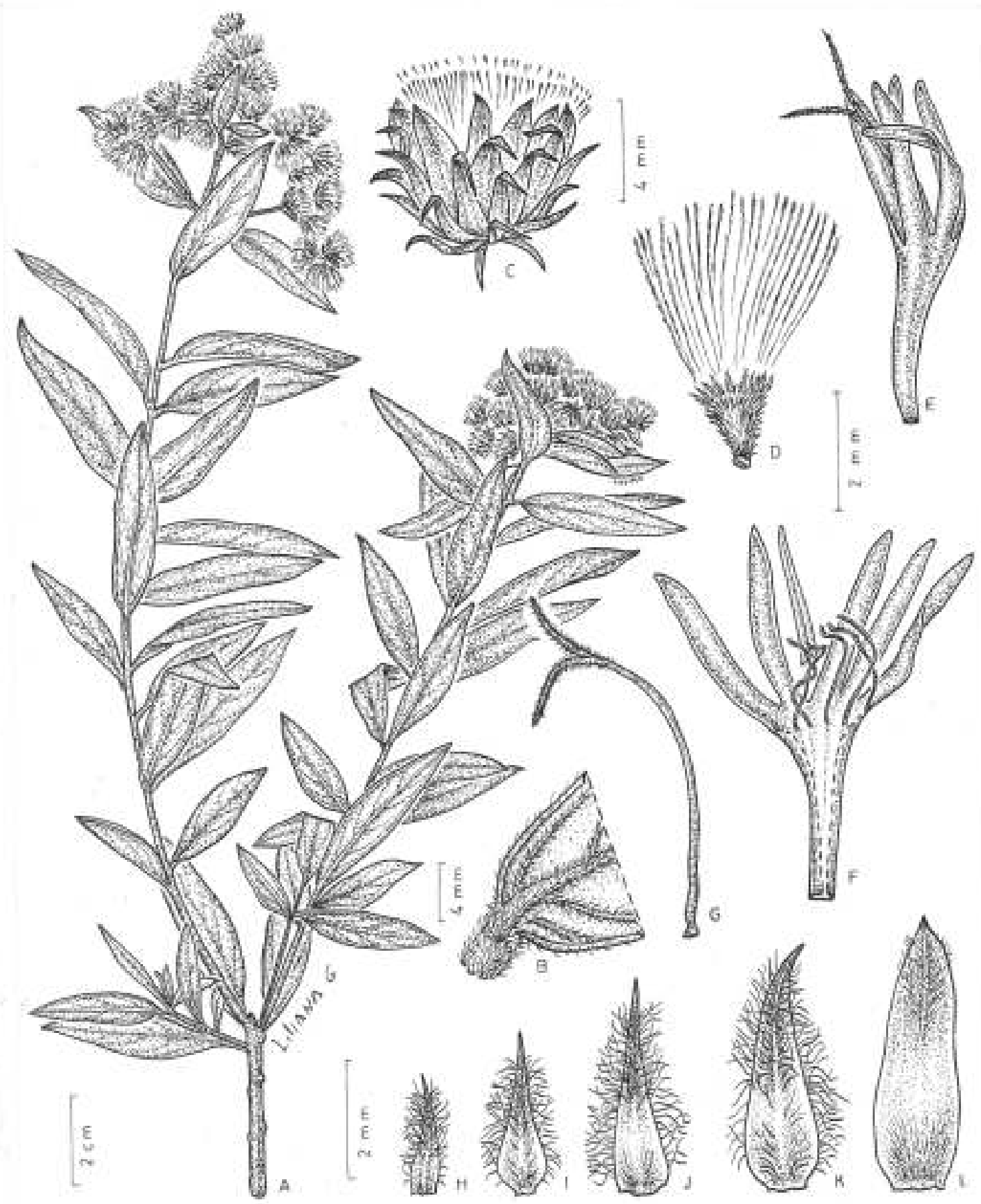

FIGURE 8. Lepidaploa decumbens. A. Plant. B. Abaxial leaf surface detail. C. Capitula. D. Cypsela and pappus. E. Floret. F. Floret dissected with anther detail. G. Style. H-I. Outer phyllaries. K-L. Inner phyllaries.

Herbs $0.2-0.6 \mathrm{~m}$ tall; branches glabrescent. Leaves distichous, cauline, internodes ca. $1 \mathrm{~cm}$ long; sessile, blade 7-10 $\times 0.8-1.34 \mathrm{~cm}$, membranaceous, weakly rugose, lanceolate, apex largely acute, margins entire, revolute, base cuneate, both surfaces strigose; venation camptodromous. Capitulescence short seriate-cymose with capitula sessile, 1.6-3.6 $\mathrm{cm}$ long, axis glabrescent, brown. Involucre campanulate, $7-8 \mathrm{~mm}$ in diam., phyllaries 5-6-seriate, chestnut, scarious, densely tomentose, outer oval-lanceolate, apex apiculate-recurved, inner lanceolate, apex apiculate-recurved. Florets 15-20, corolla violet, tube 2.5-3 mm long, glabrous, lobes 3.5-4 mm long, lanceolate, apex glandular; apical anther appendages acute, base sagittate; basal stylar node enlarged. Cypsela turbinate to obconic, 1.5-2 mm long, velutinous; carpopodium anullar. Pappus white. 
Selected specimens examined - BRASIL. Santa Catarina: Garuva, Morro Crista, 19 January 1961, R. Reitz \& R. M. Klein 10647 (HBR). idem, 23 March 1961, R. Reitz \& R. M. Klein, 10895 (HBR). Minas Gerais: Parque Nacional do Caparaó, 14.VI.1991, G. Hatschbach \& D. Guimarães 55471 (CTES).

Distribution and habitat - In southern South America Lepidaploa decumbens is restricted to the states of Paraná (Dematteis \& Almeida 2015) and Santa Catarina (Cabrera \& Klein 1980) in Brazil. In Santa Catarina this species was found in the Cerrado (Figure 7).

Phenology - The species blooms between January and March.

Notes - Lepidaploa decumbens can be recognized by the following combination of characters: apiculate-recurved phyllaries, lanceolate leaves with revolute margins, camptodromous venation and short inflorescence $(1.6-3.6 \mathrm{~cm}$ long).

6. Lepidaploa eriolepis (Gardner) Robinson (1990: 487). Vernonia eriolepis Gardner (1846: 224). Type:-BRAZIL. Without locality, G. Gardner 1718 (syntypes BR! F! GH! K!, NY! S! [online image!]). Figure 9.

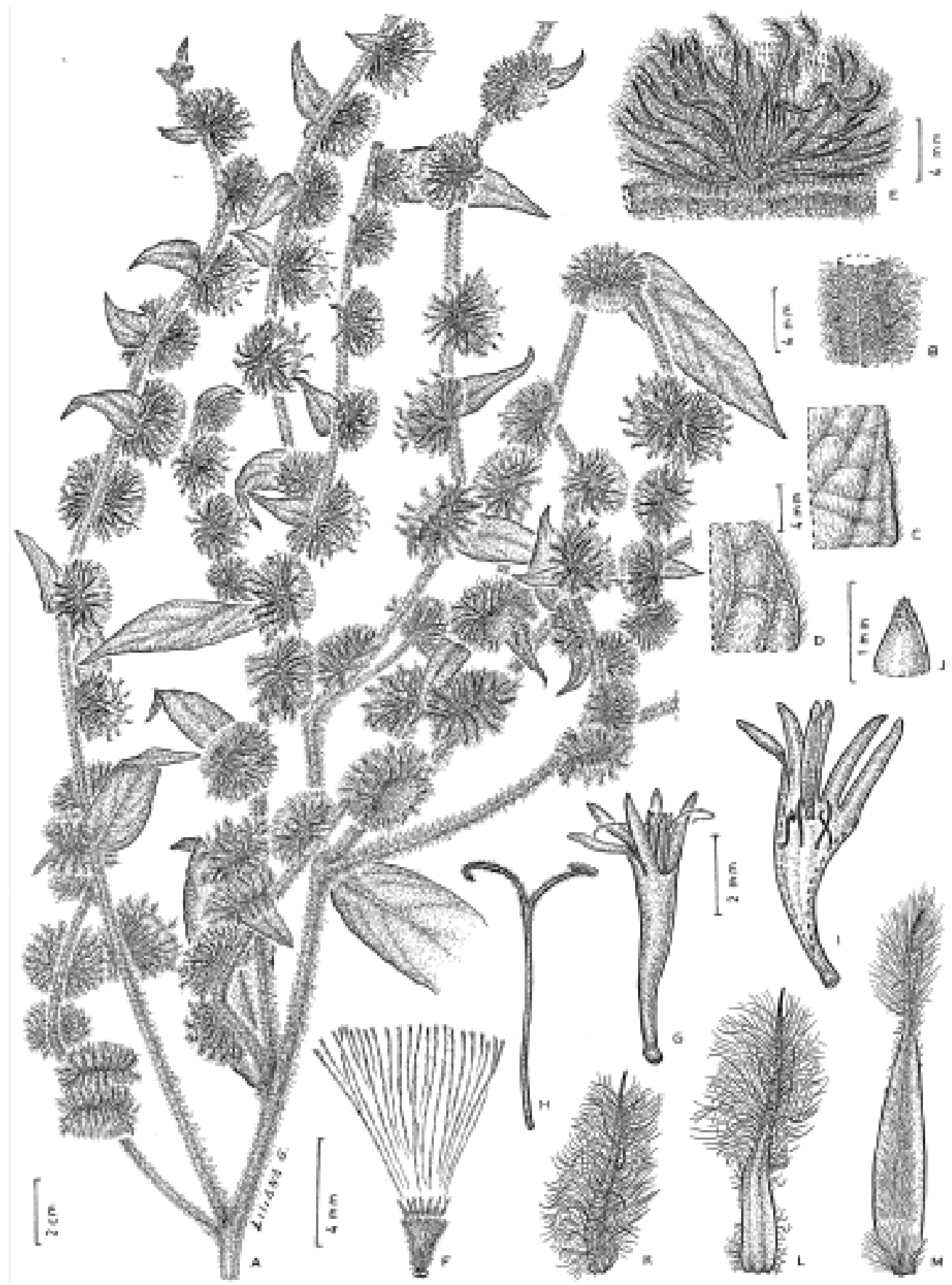

FIGURE 9. Lepidaploa eriolepis. A. Plant. B. Stem detail. C. Abaxial leaf surface detail. D. Abaxial leaf surface detail. E. Capitula. F. Cypsela and pappus. G. Floret. H. Style. I. Floret dissected with anther detail. J. Corolla lobe detail. K. Outer phyllaries. L-M. Inner phyllaries. 
Herbs, subshrubs or erect shrubs $0.9-2 \mathrm{~m}$ tall; branches densely strigose-tomentose, slightly ribbed. Leaves distichous, cauline, internodes 4.2-4.9 cm long, petioles 7.7-9 mm long, blade 12.2-15.4 $\times 4.1-6 \mathrm{~cm}$, membranaceous, rugose, ovate-lanceolate, apex caudate, margins denticulate, base attenuate, both surfaces densely strigose-tomentose; venation eucamptodromous-reticulodromous. Capitulescence seriate-cymose with capitula sessile, $8.3-17.4 \mathrm{~cm}$ long, axis densely strigose-tomentose, ferruginous. Involucre widely campanulate, $8.7-10.5 \mathrm{~mm}$ in diam., phyllaries 5-6seriate, chestnut, membranaceous, densely strigose-tomentose, outer oval-lanceolate, apex apiculate, inner ellipticlanceolate, apex acute. Florets 35-40, corolla white, tube 4.5-5 mm long, glabrous, lobes 2-2.5 mm long, lanceolate, apex setose; apical anther appendages acute, base sagittate; basal stylar node enlarged. Cypsela turbinate to obconic, 1.5-2 mm long, velutinous; carpopodium anullar. Pappus chestnut.

Specimens examined - BRASIL. Paraná: Antonina, Usina Hidrelétrica Parigot de Souza, Cota 800, 5 October 2006, J.M. Silva 5007 (CTES, MBM). Santa Catarina: Santo Amaro da Imperatriz, Cova da Onça, 12 August 2009, A. Stival-Santos 785 (MBM).

Distribution and habitat - Lepidaploa eriolepis is scarcely distributed in the study region, occurring exclusively in Paraná and Santa Catarina, Brazilia. In these states this species grows in the Atlantic Rainforest or the Cerrado (Figure 10).

Phenology - Collected with flowers from June to December.

Notes-The species can be recognized by its heads with 35-40 florets, restricted distribution, presence of a strigose-tomentose and ferruginous indumentum covering the whole plant (branches, leaves, phyllaries), and pappus chestnut.

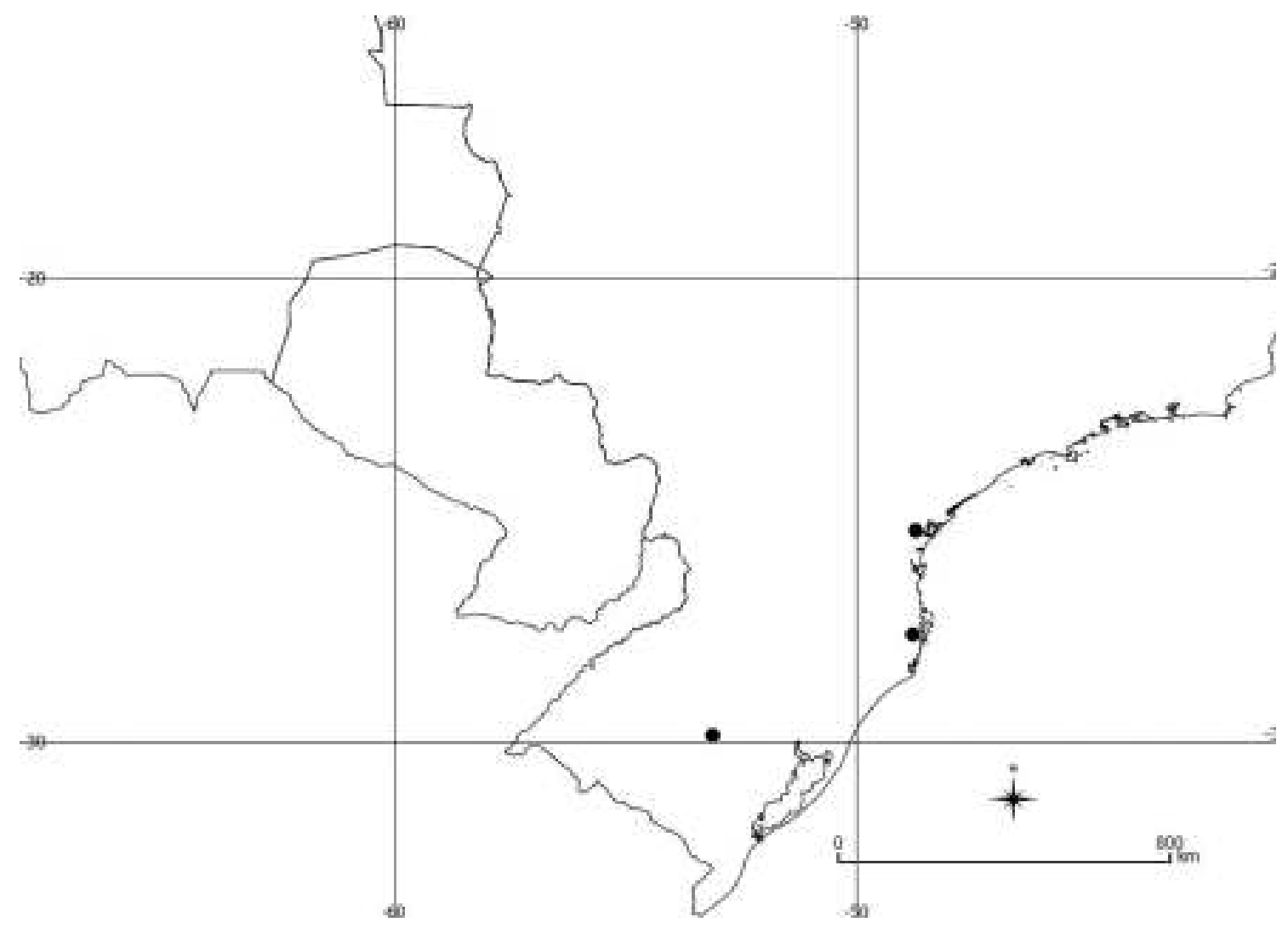

FIGURE 10. Geographical distribution of L. eriolepis (circle) in Cone Sur.

7. Lepidaploa novarae (Cabrera) Vega \& Dematteis (2012: 269). Vernonia novarae Cabrera (1997: 255).

Type:-ARGENTINA. Salta province, Santa Victoria department, Parque Nacional Baritú, between Quebrada La Gateada and Quebrada

Seca, 20 Septiember 1990, L. J. Novara 9993 (holotype MCNS! [photo!]; isotypes M!, SI! [photo!]). Figure 11.

Clambering shrubs 1-2 m tall; branches pubescent. Leaves distichous, cauline, internodes 3.3-5.5 cm long, petioles 5$10 \mathrm{~mm}$ long, blade 7-15 × 1.5-3.5 cm, membranaceous, rugose, elliptic-lanceolate or lanceolate, apex acute, margins entire, rarely sinuate, base attenuate, adaxial surfaces glabrous, abaxial surface pubescent or glabrous; venation camptodromous-eucamptodromous. Capitulescence seriate-cymose with capitula sessile, $4.7-11.3 \mathrm{~cm}$ long, axis densely tomentose-velutinous, brown. Involucre narrowly campanulate, 6-7 $\mathrm{mm}$ in diam., phyllaries 5-6-seriate, 
brown, scarious, glabrous or pubescent, outer oval-lanceolate, apex apiculate, inner elliptic-lanceolate, apex acute. Florets 20-25, corolla white, tube 3-6 mm long, glabrescent, lobes 2.5-3.5 mm long, lanceolate, apex setose-glandular; apical anther appendages acute, base obtuse; basal stylar node enlarged. Cypsela turbinate to obconic, 2-2.3 mm long, sericeous, idioblasts present; carpopodium anullar. Pappus white or grayish.

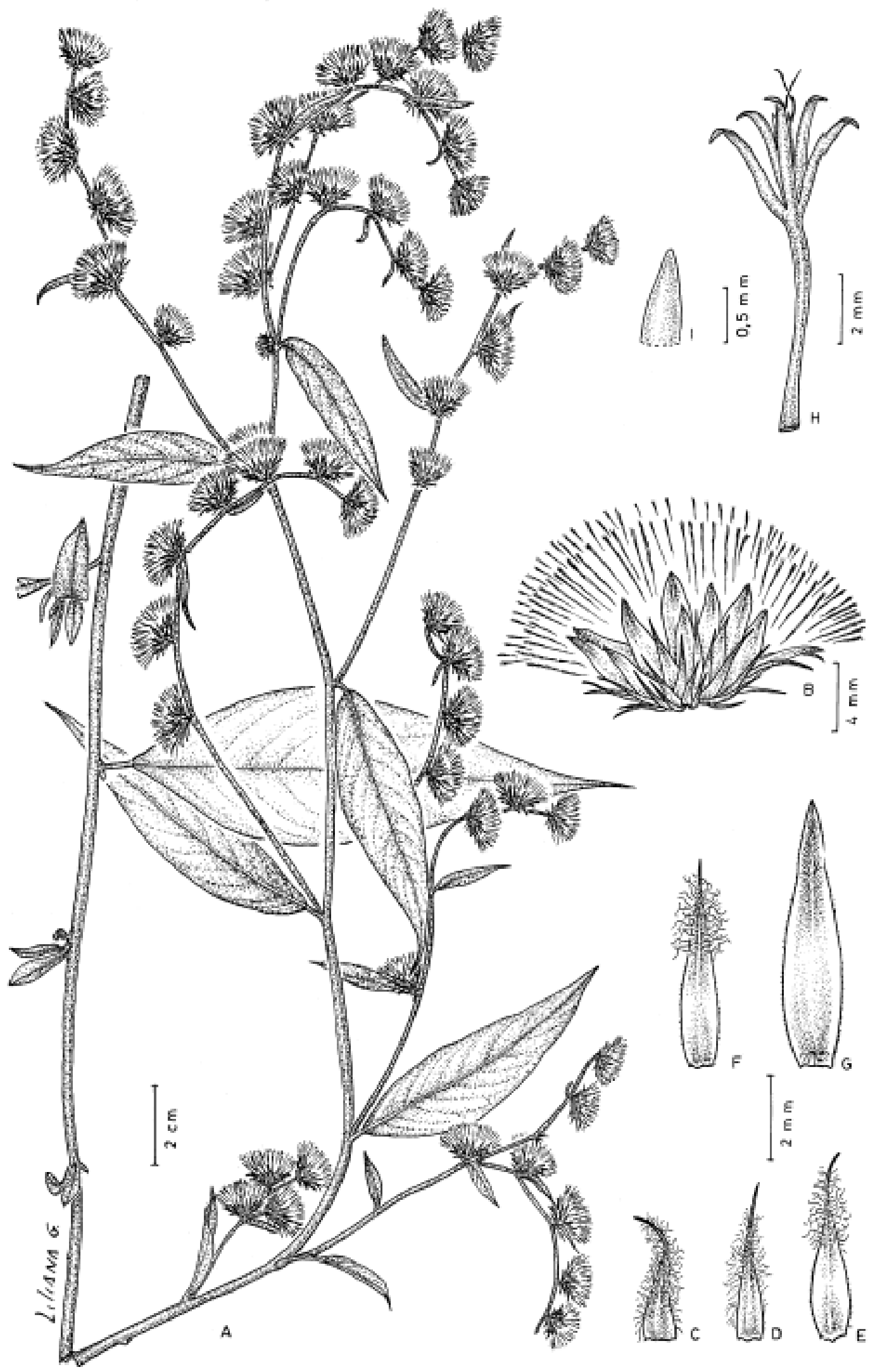

FIGURE 11. Lepidaploa novarae. A. Plant. B. Capitula. C-D. Outer phyllaries. E-G. Inner phyllaries. H. Floret. I. Corolla lobe detail. Source: Marques \& Dematteis (2014). 
Selected specimens examined -ARGENTINA. Salta: Departamento de Santa Victoria, Parque Santa Victoria, Camino a río San José desde desvío de camino de los Toldos a Lipeo, 28 September 1998, O. Ahumada 8177 (CTES). Salta Capital, Parque San Martín, entrando por pista de aterrizaje de Los Toldos, bordeando la costa del río Toldo, 03 October 1998, O. Ahumada 8365 (CTES).

Distribution and habitat - Lepidaploa novarae was reported only from the province of Salta in Argentina and, therefore, is endemic to this region. In Salta, the species was found in the departments of Salta and Santa Victoria. According to Marques \& Dematteis (2014), this species can also be found in the department of Óran, Salta. The species grows in the "yungas salteñas" (North-Central Humid Andes) between 600-1800 m a.s.l. (Figure 12).

Phenology - Collected with flowers in August and September.

Notes - Lepidaploa novarae is similar to L. tarijensis, which also occurs in Salta (Argentina), but the first species grows only in Salta while L. tarijensis occurs in Salta and Bolivia. Both species are clambering shrubs and have glabrous or glabrecent leaves. However, L. novarae is distinct from the similar species because of its involucre 6-7 (versus 8-10) $\mathrm{mm}$ long, presence (versus absence) of glandular trichomes on the corolla lobes, and cypselae with idioblasts (versus without idioblasts).

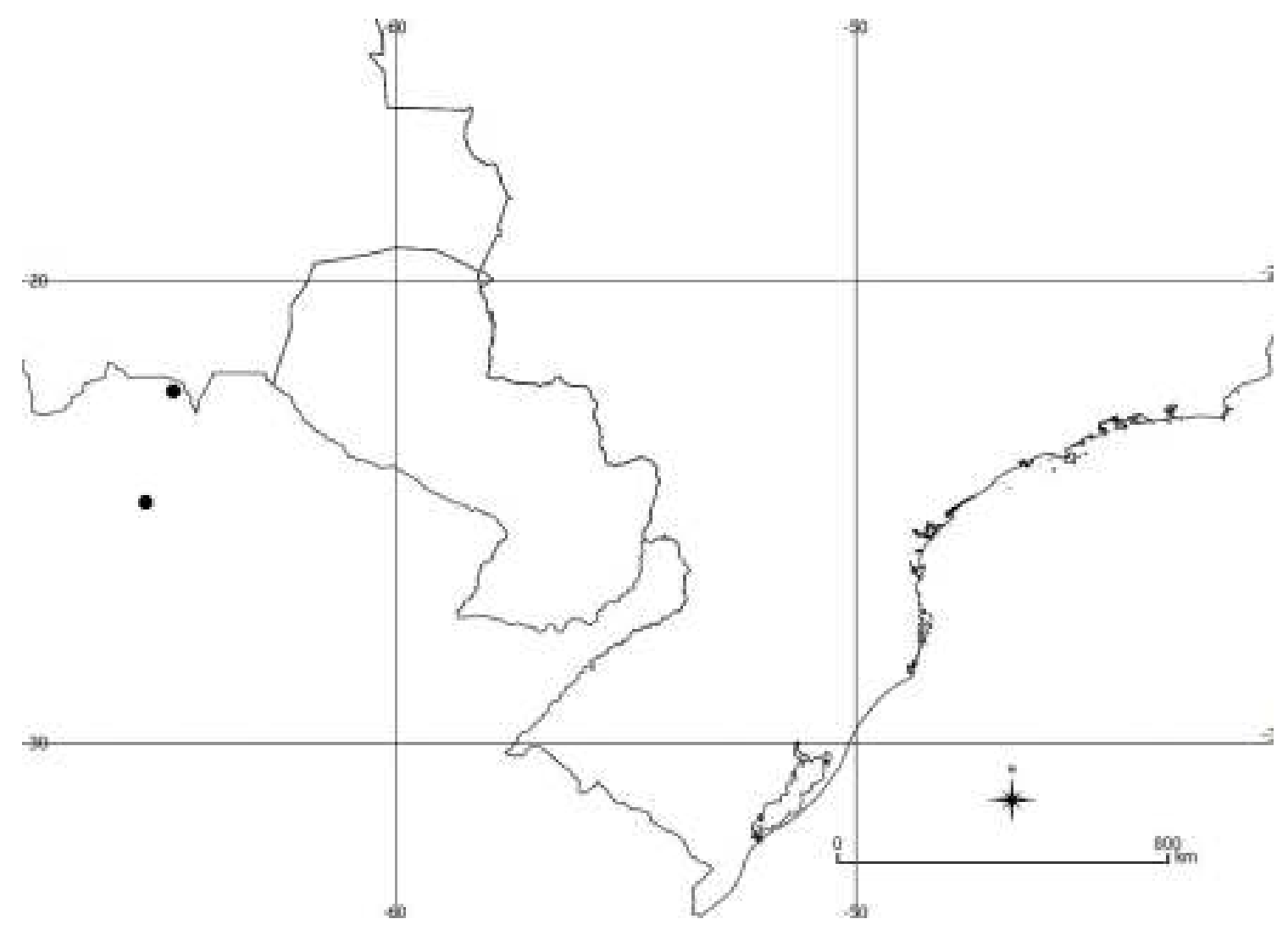

FIGURE 12. Geographical distribution of L. novarae (circle) in Cone Sur.

\section{Lepidaploa pseudomuricata Robinson (1995: 395).}

Type:-BRAZIL. Santa Catarina state, Serra da Boa Vista, São José, 700 m, 12 December 1990, R. Reitz \& R. M. Klein 10614 (holotype US! [photo!]; isotypes HBR! LP). Figure 13.

Erect subshrubs or shrubs $0.8-2 \mathrm{~m}$ tall; branches strigose, prominently ribbed. Leaves spirally alternate, cauline, internodes 2-5 cm long, petioles $0.4-1.3 \mathrm{~mm}$ long, blade $9.5-10.1 \times 1.5-3.4 \mathrm{~cm}$, membranaceous to chartaceous, rugose, lanceolate or oblong-lanceolate, apex acute to caudate, margins denticulate, base cuneate to attenuate, both strigose; venation eucamptodromous-reticulodromous. Capitulescence seriate-cymose with capitula sessile, paniculiform, 13.9-15.5 cm long, axis puberulent to strigose, whitish. Involucre campanulate, 6-7.2 $\mathrm{mm}$ in diam., phyllaries 3-4-seriate, chestnut, membranaceous, strigose, outer oval-lanceolate, apex apiculate, inner lanceolate, apex apiculate. Florets 19-23, corolla lilac or violet, tube 2.9-5.5 mm long, glabrous, lobes 2.6-3.9 mm long, lanceolate, apex glandular; apical anther appendages acute, glandular, lanceolate, base sagittate; basal stylar node narrow. Cypsela turbinate to obconic, 2.2-2.8 mm long, setose; carpopodium anullar. Pappus white. 


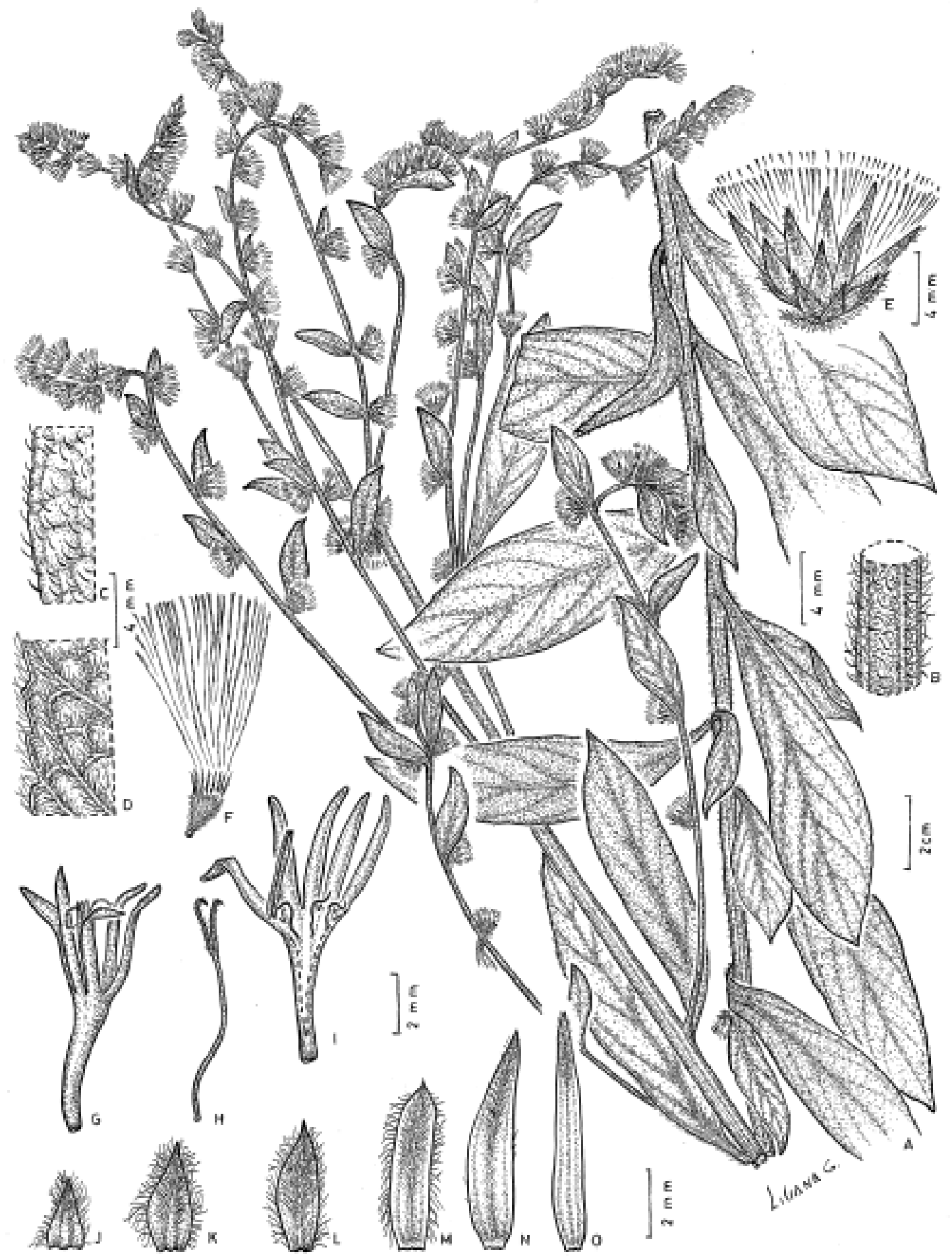

FIGURE 13. Lepidaploa pseudomuricata. A. Plant. B. Stem detail. C. Abaxial leaf surface detail. D. Abaxial leaf surface detail. E. Capitula. F. Cypsela and pappus. G. Floret. H. Style. I. Floret dissected with anther detail. J-L. Outer phyllaries. M-O. Inner phyllaries.

Selected specimens examined-ARGENTINA. Misiones: San Pedro, Camino de tierra que une ruta provincial 17 con ruta nacional 14 a la altura de Piñalito Sur, 13 January 2007, H.A. Keller 3921 (CTES). BRASIL. Paraná: Antonina, Bairro Alto, 10 February 2006, G. Hatschbach 79554 (CTES). Santa Catarina: Bom Jardim da Serra, Fazenda Papagaios, 26 February 2011, M. Verdi 5909 (FURB). Rio Grande do Sul: Bom Jesus, Santo Inácio, 11 March 2005, G. Hatschbach 79077 (CTES).

Distribution and habitat - The species is restricted to the south of Brazil and is known in Argentina through a unique collection from the province of Misiones. Lepidaploa pseudomuricata inhabits fields and wetland regions but is commonly found on margins or under canopy of the Atlantic Rainforest (Figure 14). 
Phenology - The species blooms between April and December.

Notes - The species can be easily differentiated from the other species that occur in southern South America by glandular trichomes on its anthers, prominently ribbed branches, erect subshrubby or shrubby habit and narrow basal stylar node.

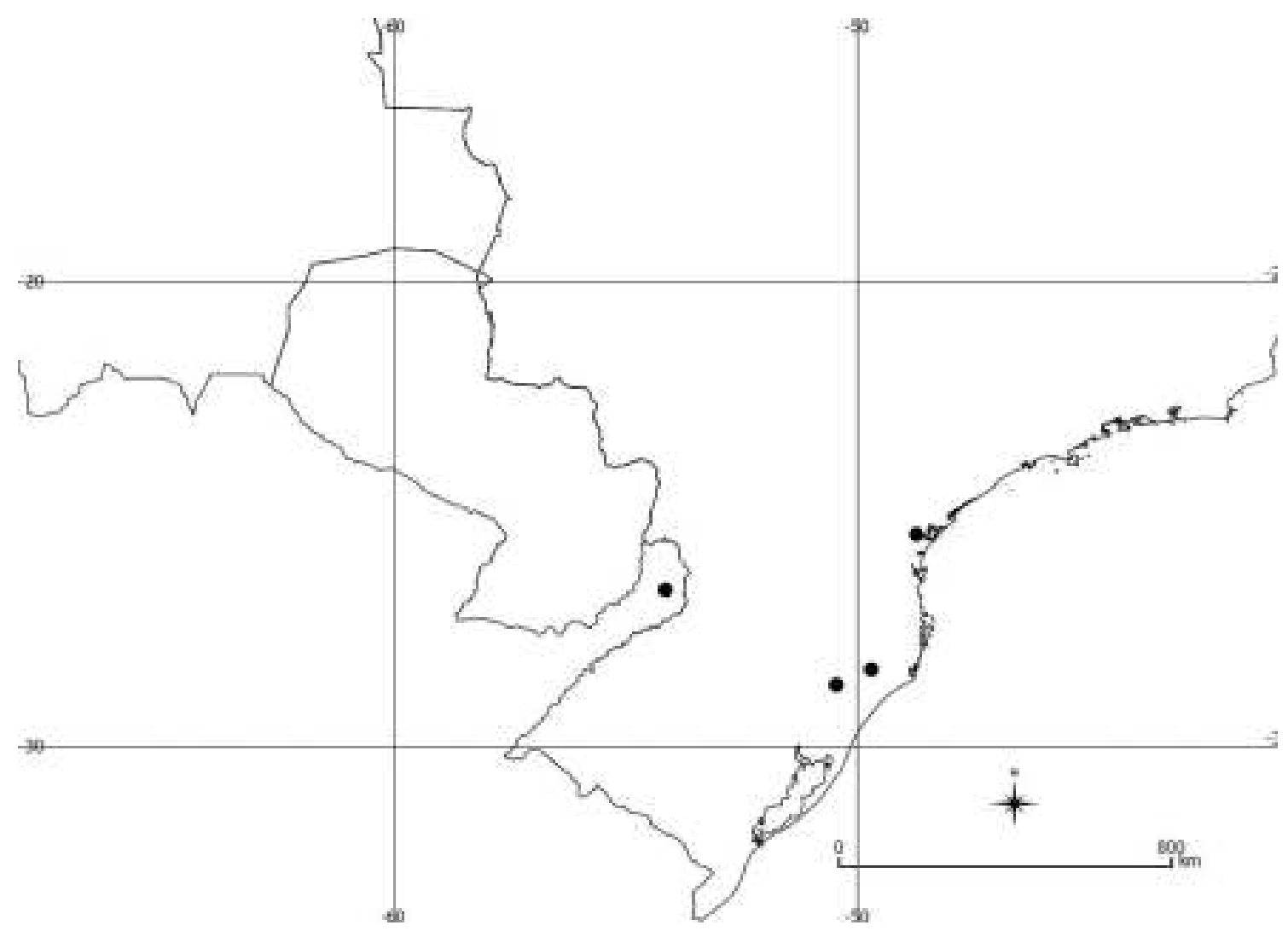

FIGURE 14. Geographical distribution of L. pseudomuricata (circle) in Cone Sur.

9. Lepidaploa psilostachya (DC.) Robinson (1990: 491). Vernonia psilostachya Candolle (1836: 43).

Type:-BRAZIL. São Paulo state, without locality, 1835, P. W. Lund 878 (holotype G-DC! [online image!]). Figure 15.

Subshrubs 0.3-0.45 m tall; branches tomentose-glandular. Leaves distichous, basal and cauline, internodes $2.6-4.5 \mathrm{~cm}$ long, sessile, blade 1.4-3.87 × 0.4-1.2 cm, membranaceous, smooth, basal obovate-lanceolate, cauline lanceolate, apex acute, margins denticulate to serrulate, revolute, base attenuate, adaxial surface strigose, abaxial surface tomentose; venation camptodromous. Capitulescence seriate-cymose with capitula sessile, ca. $9 \mathrm{~cm}$ long, axis tomentose-glandular, golden. Involucre campanulate, $8-10 \mathrm{~mm}$ in diam., phyllaries 5-6-seriate, brown to reddish, membranaceous, villous to tomentose, outer oval-lanceolate, apex largely apiculate, inner elliptic-lanceolate, apex acute to acute-apiculate. Florets 21-23, corolla lilac to violet, tube 3.2-4 mm long, glabrous, lobes 2-2,5 mm long, lanceolate, apex setose; apical anther appendages obtuse, base obtuse; basal stylar node enlarged. Cypsela turbinate to obconic, $1.55-1.7 \mathrm{~mm}$ long, setose, idioblasts present; carpopodium anullar. Pappus white.

Selected specimens examined-ARGENTINA. Misiones: San Ignacio, Casa de H. Quiroga, 16 February 2009, M. Dematteis 3047 (CTES). BRASIL. Paraná: Tibagi, Guartelá, 14 December 2009, L.P. Deble 12020 (CTES).

Distribution and habitat-The species is scarcely distributed in the study region, occurring only in Paraná (Brazil) and Misiones (Argentina). According to Dematteis \& Cabrera (2009), L. psylostachya also occurs in Paraguay in the departments of Alto Paraná and Cordillera. In southern South America it grows on stony fields of the Atlantic Rainforest (Figure 16).

Phenology —Collected with flowers in November, February, and July.

Notes - Lepidaploa psilostachya is similar to L. amambaia. However, L. psilostachya is distinguished from the latter species by having both basal and cauline leaves and acute leaf apex. See comments under L. amambaia. 


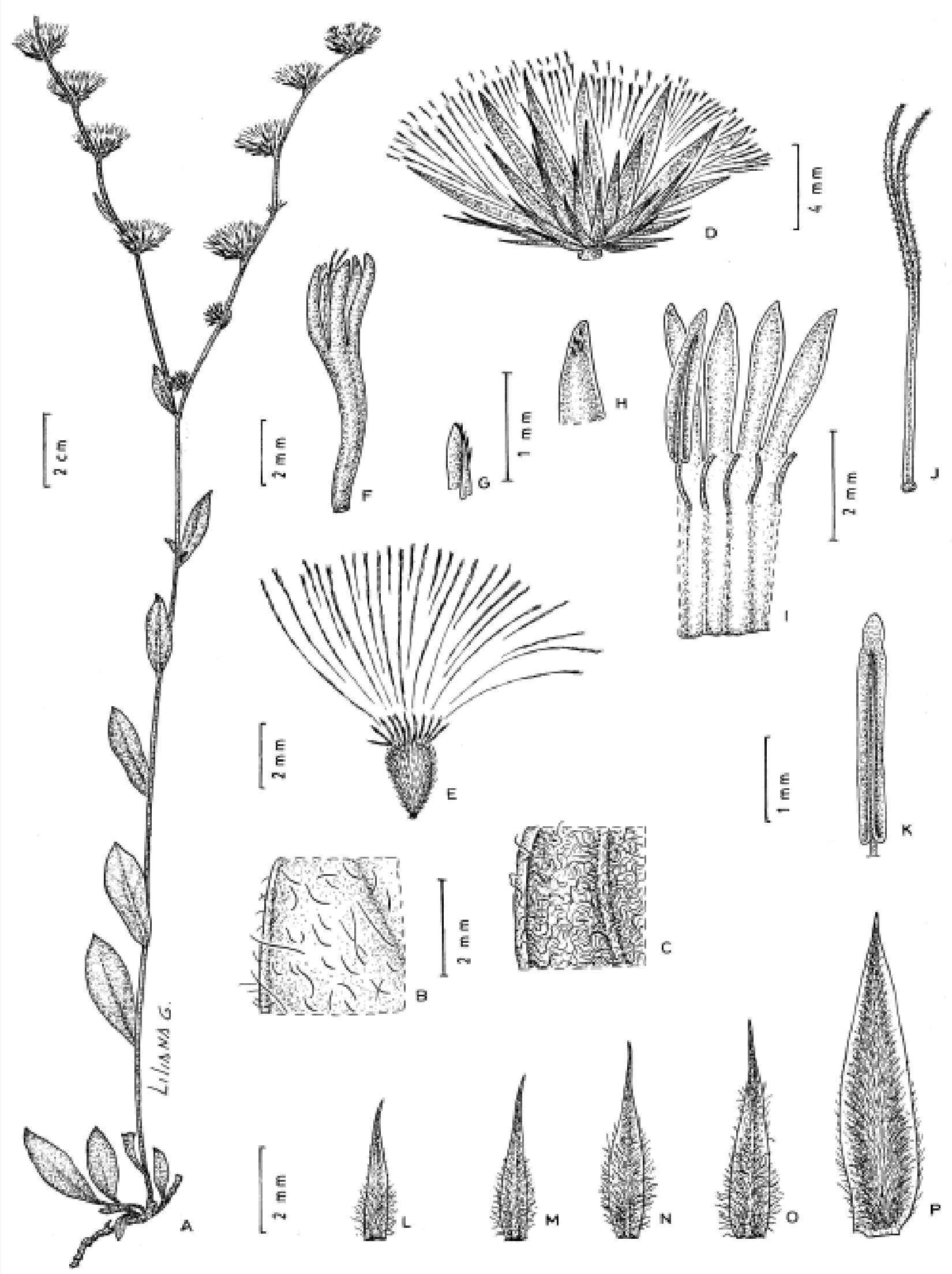

FIGURE 15. Lepidaploa psilostachya. A. Plant. B. Abaxial leaf surface detail. C. Abaxial leaf surface detail. D. Capitula. E. Cypsela. F. Floret. G-H. Corolla lobe detail. I. Floret dissected. J. Style. K. Anther. L-M. Outer phyllaries. N-P. Inner phyllaries. Source: Marques \& Dematteis (2014). 


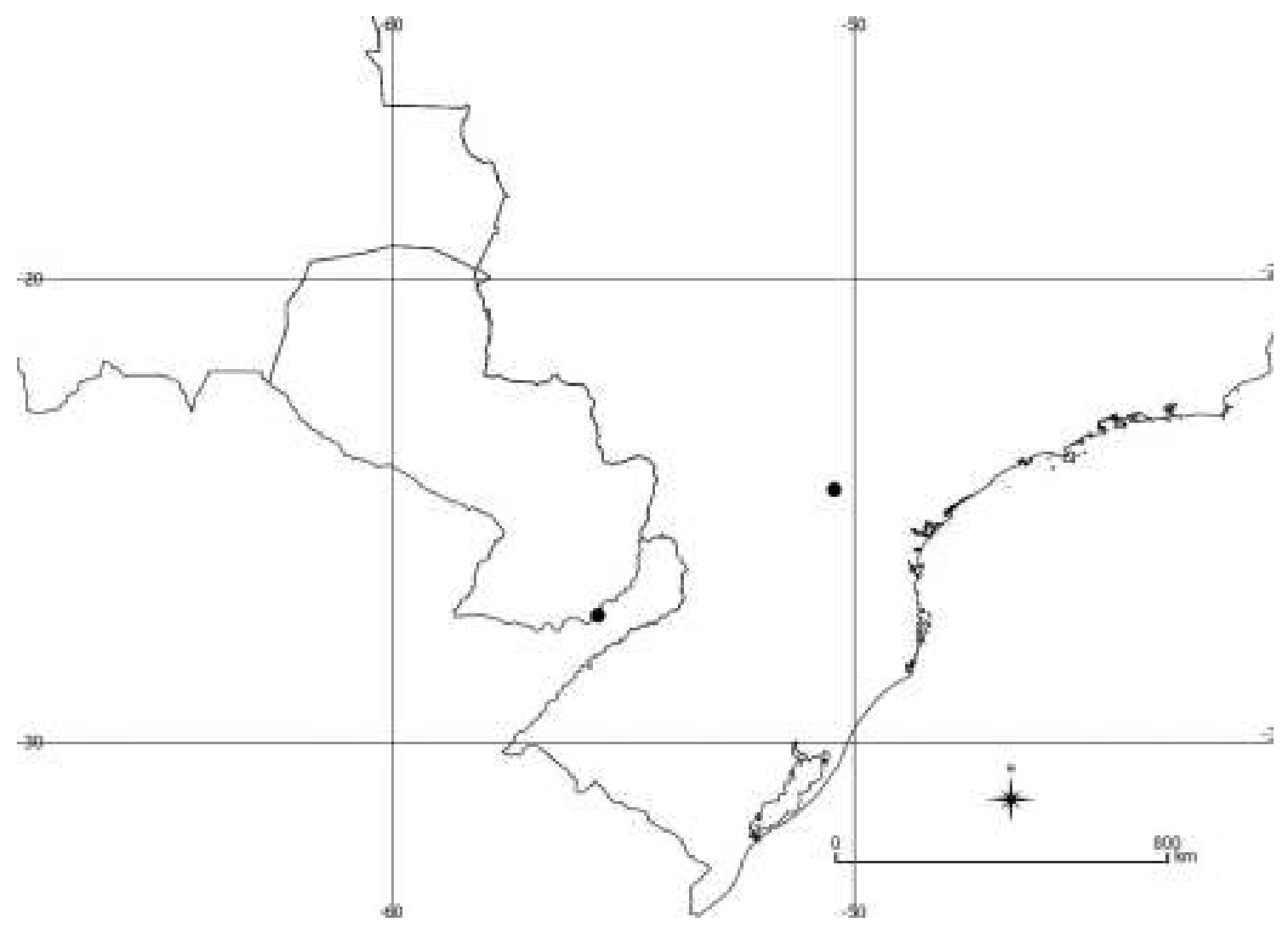

FIGURE 16. Geographical distribution of L. psilostachya (circle) in Cone Sur.

10. Lepidaploa remotiflora (Rich.) Robinson (1990: 491). Vernonia remotiflora Richard (1792: 112).

Type:-FRENCH GUIANA. Without locality, 1792, J. B. Leblond 336 (lectotype G! [photo!], designated by Pruski (1998: 480); isolectotypes C! P! US!). Figure 17.

Herbs or subshrubs $0.3-0.6(-1.20) \mathrm{m}$ tall; branches pubescent. Leaves distichous, cauline, internode $2.2-3.6 \mathrm{~cm}$ long, sessile, blade 13.5-14.6 × 4.1-4.7 cm, membranaceous, smooth, oval or oval-lanceolate, apex acute, margins serrulate or denticulate, base attenuate, both surfaces strigose; venation eucamptodromous-reticulodromous. Capitulescensce seriate-cymose with capitula sessile, paniculiform, $9.7-42 \mathrm{~cm}$ long, axis densely velutinous, golden. Involucre campanulate, 6-8 mm in diam., phyllaries 5-6-seriate, greenish with blackened apex, scarious, pubescent, outer linearlanceolate, apex apiculate, inner lanceolate, apex acute. Florets 21-23, corola violet, tube 3.5-5 mm long, glabrous, lobes 2.5-3 mm long, lanceolate, apex glandular; apical anther appendages acute to obtuse, base obtuse or sagittate; basal stylar node enlarged. Cypsela turbinate, $1.55-1.7 \mathrm{~mm}$ long, strigose, idioblasts present; carpopodium anullar. Pappus white.

Selected specimens examined -ARGENTINA. Corrientes: Ituizangó, Centro Forestal, Villa Olivari, 05 April 1995, S.G. Tressens 5243 (CTES). Formosa: Pilagá, Costa Río Paraguay, 16 March 1979, B. Piccinini 3607 (CTES). Misiones: Eldorado, Ruta Provincial 17, Aldea Guaraní, Pozo Azul, 04 April 2002, H.A. Keller 1778 (CTES). BRASIL. Paraná: Campo Mourão, 02 February 1962, G. Hatschbach 8845 (MBM). Rio Grande do Sul: Bom Jesus, Santo Inácio, 11 March 2005, G. Hatschbach 79080 (MBM). PARAGUAY. Amambay: Amambay, Colina Estrella, 45 km NW de P.J. Caballero, 08 December 1997, A. Schinini 30545 (CTES). Caazapá: Santa Ursula, 55 km de Yuty, 23 March 1993, A. Schinini 27871 (CTES). Canindeyú: Reserva Natural del Bosque Mbaracayú, 11 km del Puerto "Yeyuí-mi”, 12 February 1997, A. Schinini 33245 (CTES). Central: Central, Areguá, Isla Valle, 10 June 1987, N. Soria 1513 (FCQ). Cordillera: Tobatí, Ybitú Silla, 03 March 1991, E. Zardini 26960 (FCQ). Guairá: Cordillera de Ybytyruzú, Ruta de Cantera Jhú, 27 September 1989, E. Zardini 14889 (FCQ). Itapúa: Capitán Miranda, 4,2 km N del Hotel Tirol detrás del barrio Conavi, 07 October 1993, A. Krapovickas 44450 (CTES). Ñeembucú: Paraguay, Ñeembucú, Estancia Redondo, 29 October 2004, M. Peña-Chocarro 2210 (FCQ). Paraguarí: Paraguarí, costa del Cerro Palacios, 12 January1988, M. Ortíz 423 (FCQ). San Pedro: Río Tapiracuay, 10 km de San Estanislao, 17 February 1968, A. Krapovickas 13886 (CTES). 


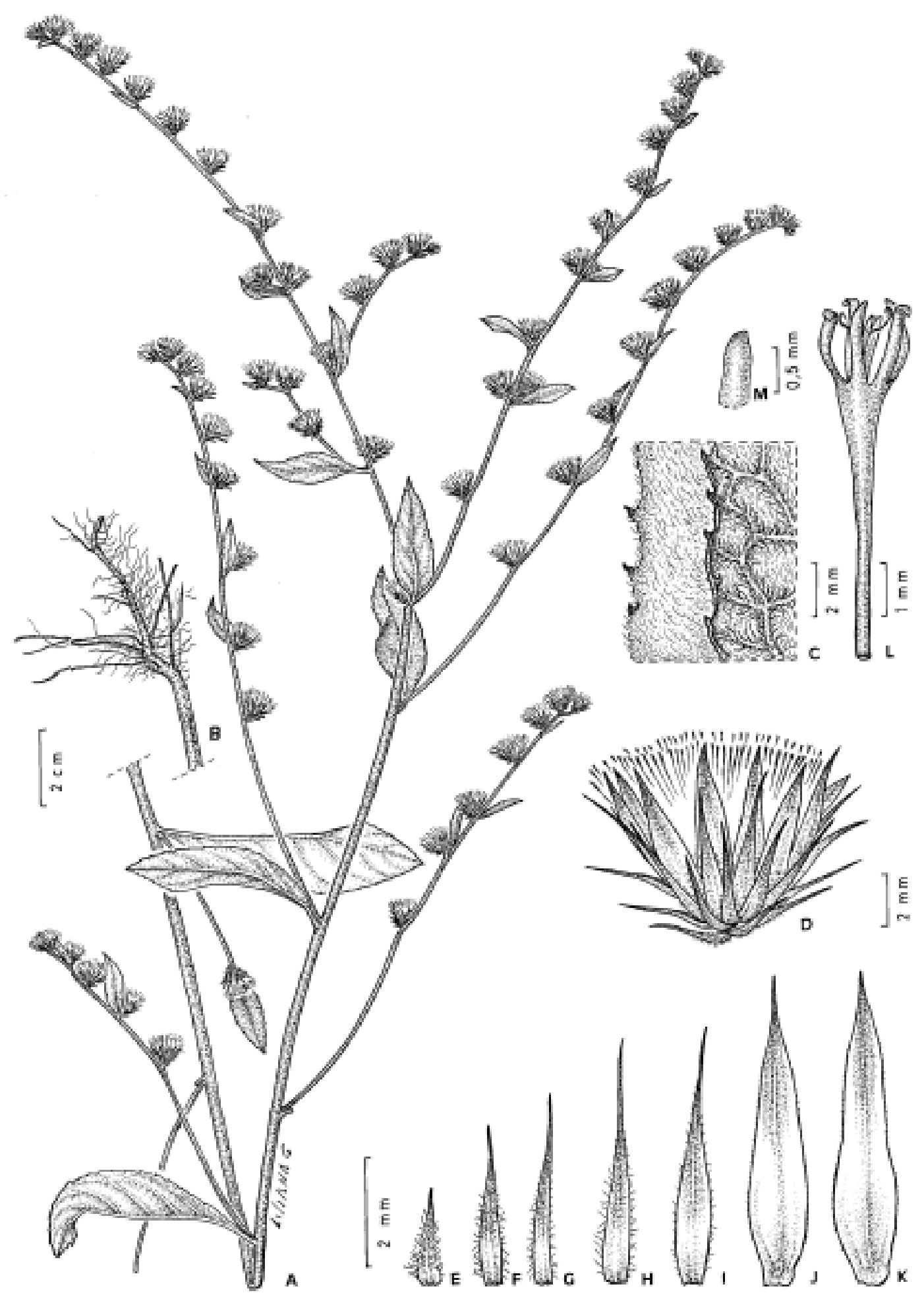

FIGURE 17. Lepidaploa remotiflora. A. Plant. B. Root. C. Margin leaf detail. D. Capitula. E-G: Outer phyllaries. G-K. Inner phyllaries. L. Floret. M. Corolla lobe detail. Source: Marques \& Dematteis (2014).

Distribution and habitat - In southern South America, the species occurs in Argentina (Corrientes, Formosa, Misiones), Brazil (Paraná and Rio Grande do Sul) and Paraguay (Amambay, Caazapá, Canindeyú, Central, Cordillera, Guiará, Itapúa, Neembucú, Paraguarí, San Pedro). According to Dematteis \& Cabrera (2009), in Paraguay this species is also found in Alto Paraná, Caaguazú, Concepción, Misiones and Presidente Hayes. The species can be possibly found in the Argentinian provinces of Tucumán and Salta (Marques \& Dematteis 2014). It inhabits crop fields, cerrado fields, wetland regions, forest margins and canopy (Figure 18).

Phenology - The species blooms throughout the year. 
Notes-This species can be confused with L. amambaia and L. setososquamosa, which also occur in southern South America, but L. remotiflora can be differentiated from both species by its acute leaf apex, eucamptodromousreticulodromous venation, inner phyllaries with acute apex and the presence of glandular trichomes on the style branches and corolla lobes. See comments under L. amambaia.

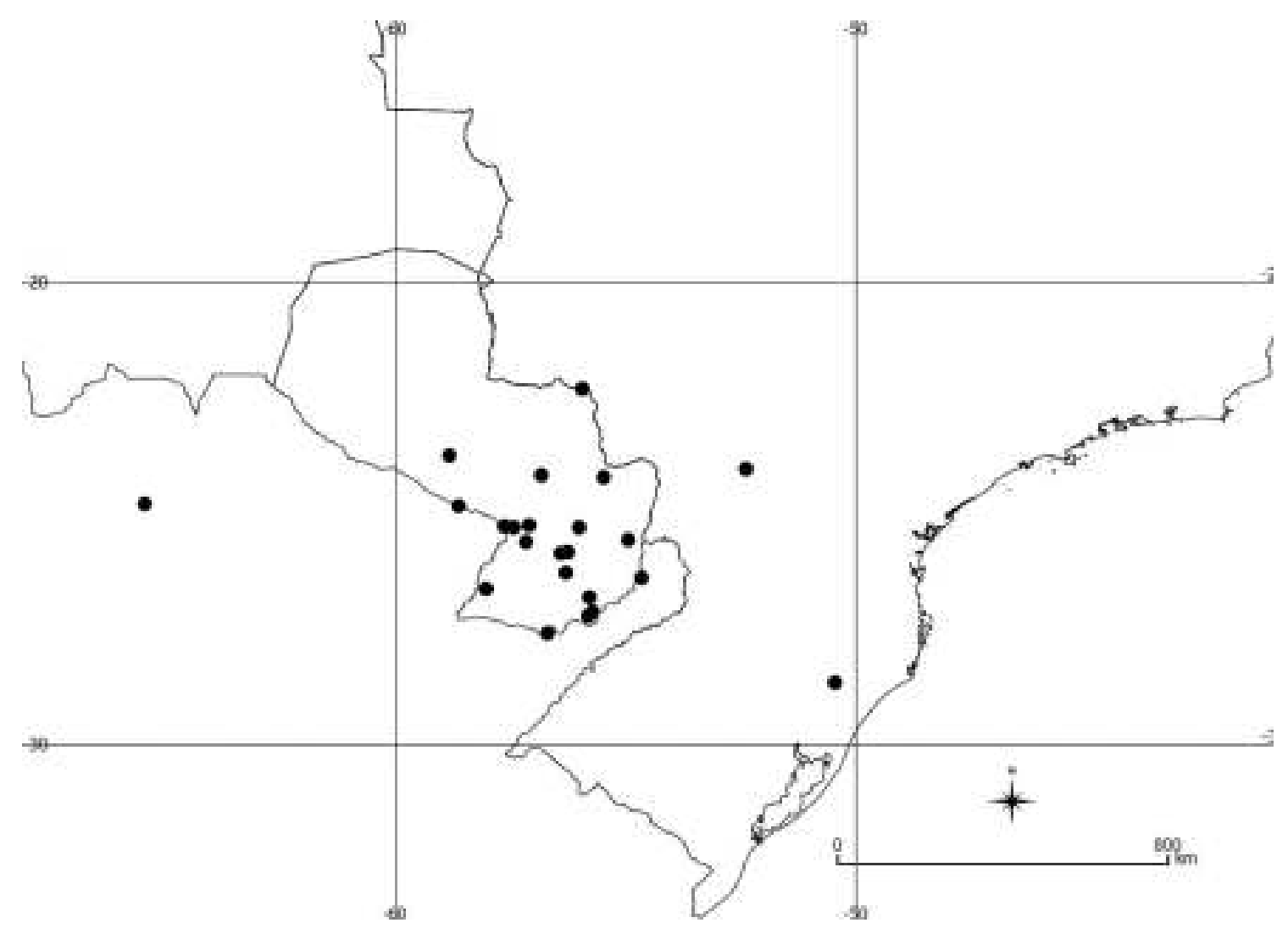

FIGURE 18. Geographical distribution of L. remotiflora (circle) in Cone Sur.

11. Lepidaploa salzmannii (DC.) Robinson (1990: 492). Vernonia salzmannii Candolle (1836: 55).

Type:-BRAZIL. Bahia, "'in umbrosis, ubi semel a me lecta”, 1830, P. Salzmann 47 (holotype G-DC! [online image!]). Figure 19.

Shrubs $0.9 \mathrm{~m}$ tall; branches sericeous, slightly ribbed. Leaves distichous, cauline, internodes $2.8-3.8 \mathrm{~cm}$ long, petioles 3-4 mm long, blade 7.5-10.5 × 1.9-2.2 cm, membranaceous, smooth, lanceolate, apex acute, margins entire, base cuneate, adaxial surfaces glabrescent, abaxial surfaces tomentose; venation eucamptodromous. Capitulescence seriate-cymose with capitula sessile, $12-13.2 \mathrm{~cm}$ long, axis sericeous, gray. Involucre campanulate, 6-7 mm in diam., phyllaries 5-6-seriate, brown, membranaceous, glabrescent, outer elliptic-lanceolate, apex apiculate, inner lanceolate, apex slightly apiculate. Florets 19-21, corolla lilac, tube 4-5 mm long, glabrous, lobes 1.6-2.5 mm long, lanceolate, apex setose-glandular; apical anther appendages obovate, base slightly sagittate; basal stylar node enlarged. Cypsela turbinate to obconic, 1.5-2 mm long, setose-glandular, idioblasts present; carpopodium anullar. Pappus beige.

Selected specimens examined -BRASIL. Paraná: Tomazina, Guaviroval, 02 September 1998, G. Hatschbach 68293 (CTES). Antonina, Reserva Biológica de Sapintanduva, 15 May 1981 G. Hatschbach 43889 (MBM).

Distribution and habitat - In the study region, Lepidaploa salzmannii was found only in the state of Parana, Brazil. According to Dematteis \& Cabrera (2009), this species also occurs in the department of Alto Paraguay, Paraguay. It grows on forest margins or under canopy in the Atlantic Rainforest (Figure 20).

Phenology - The species was found in flower in May and September.

Notes-This species is morphologically similar to L. chamissonis because of the following common characters: leaves lanceolate, petioles 3-4 mm long, cypselae setose-glandular with idioblasts. See comments under $L$. chamissonis. 


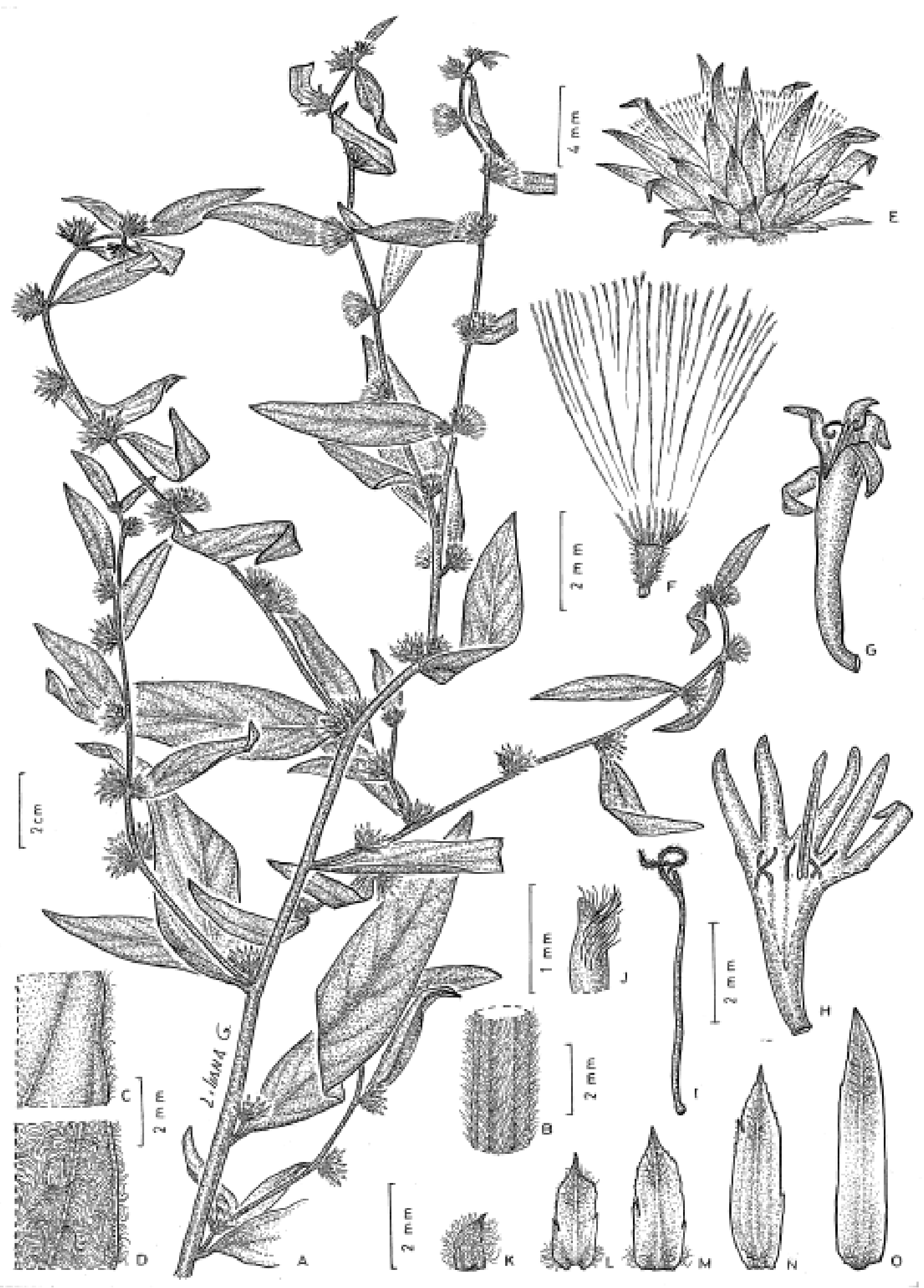

FIGURE 19. Lepidaploa salzmannii. A. Plant. B. Stem detail. C. Abaxial leaf surface detail. D. Abaxial leaf surface detail. E. Capitula. F. Cypsela and pappus. G. Floret. H. Floret dissected. I. Style. J. Corolla lobe detail. K-L. Outer phyllaries. M-O. Inner phyllaries. 


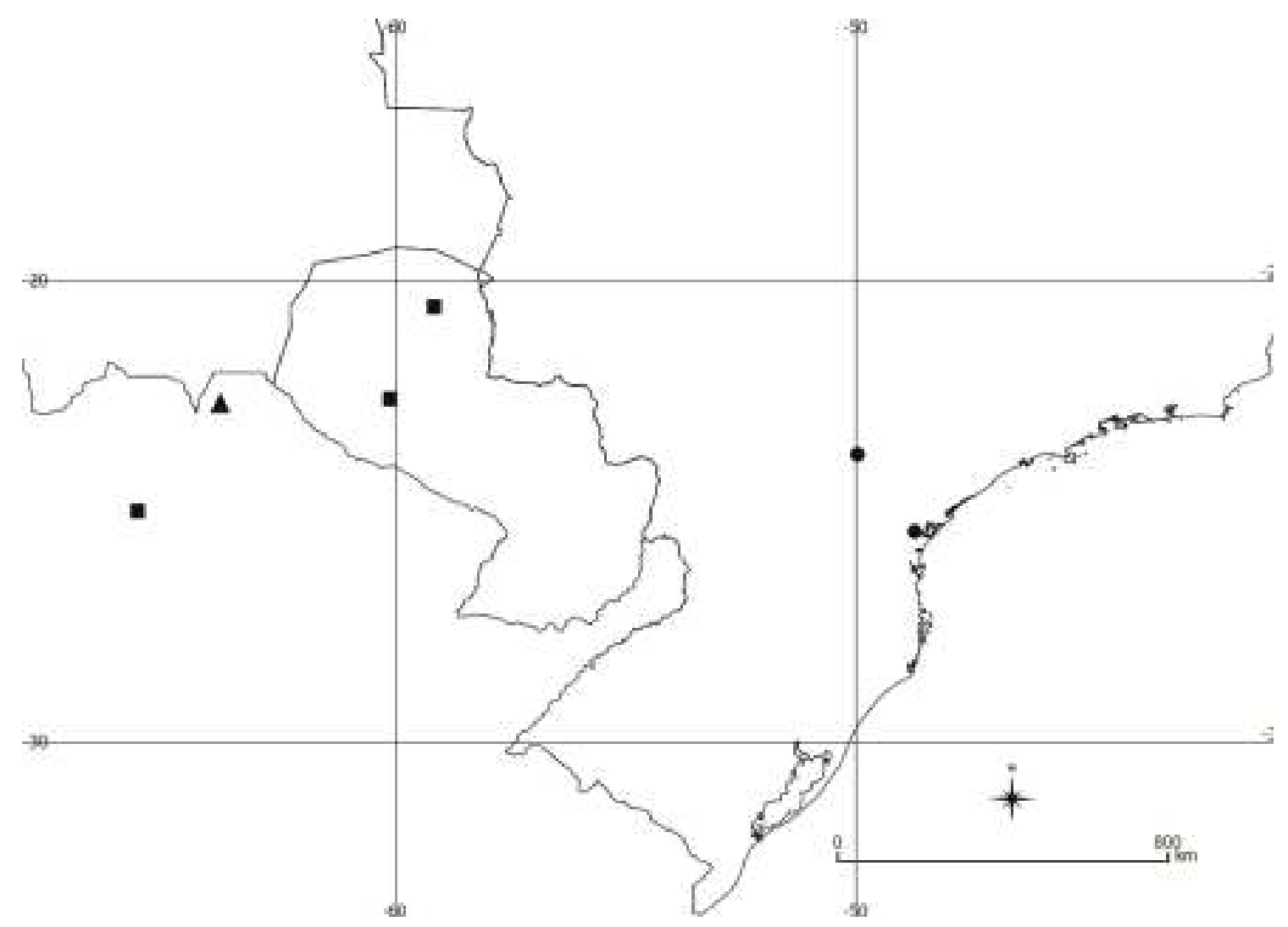

FIGURE 20. Geographical distribution of L. salzmannii (circle), L. setososquamosa (square) and L. tarijensis (triangle) in Cone Sur.

12. Lepidaploa setososquamosa (Hieron.) Angulo \& Dematteis (2012: 271). Vernonia setososquamosa Hieronymus (1897: 864).

Type:-ARGENTINA. Salta province, Tarija department, Nogalitos, February 1873, P. G. Lorentz \& G. H. E. W. Hieronymus 1205 (lectotype COND! [photo!], designated by Cristóbal \& Dematteis (2003: 47)). Figure 21.

Subshrubs 0.4-0.6 m tall; branches setose. Leaves distichous, cauline, internodes 1.1-2.1 cm long, sessile, blade 2.5$10.2 \times 0.6-3.2 \mathrm{~cm}$, membranaceous, smooth, oval, ovate-lanceolate, apex apiculate, margins denticulate, base attenuate, both surfaces setulose; venation eucamptodromous-brochidodromous. Capitulescence seriate-cymose or paniculiform with capitula sessile, 10-20 cm long, axis densely velutinous, brown to green-yellowish. Involucre campanulate, 12-14 $\mathrm{mm}$ in diam., phyllaries 5-6-seriate, brown or greenish with blackened apex, scarious to membranaceous, tomentose, outer linear-lanceolate, apex aristate, inner elliptic-lanceolate, apex aristate. Florets 23-25, corolla violet, tube 4-5 $\mathrm{mm}$ long, glabrous, lobes $3.5-5 \mathrm{~mm}$ long, lanceolate, apex setose; apical anther appendages acute, base slightly obtuse; basal stylar node enlarged. Cypsela turbinate, $1.55-1.7 \mathrm{~mm}$ long, sericeous-glandular, idioblasts present; carpopodium anullar. Pappus white.

Selected specimens examined - ARGENTINA. Salta: Rosario de Lerma, Dique Las Lomitas, Ribera Oeste, 09 February 1997 L.J. Novara 10877 (CTES). PARAGUAY. Alto Paraguay: Camino Gabino Mendoza a General Garay, 31 March 1995, R. Degen 3298 (FCQ). Boquerón: Parque Valle Natural, 12 km de Filadelfia, 28 February 1991, $R$. Vanni 2476 (CTES).

Distribution and habitat - In southern South America the species is distributed in Argentina (Salta) and Paraguay (Alto Paraguay and Boquerón). In the study region the species inhabits fields on sandy soils in the Cerrado (Figure 20).

Phenology - Collected with flowers from November to March.

Notes-This species is morphologically similar to L. remotiflora and L. amambaia, which also occur in southern South America. However, L. setososquamosa has a more restricted distribution than L. remotiflora and can be differentiated from the latter by its leaves with apiculate apex, eucamptodromous-brochidodromous venation, inner phyllaries with apiculate apex and absence of glandular trichomes on the style branches and corolla lobes. In turn, $L$. setossosquamosa is distinguished from L. amambaia by its heads with $23-25$ florets, sessile leaves $12-14 \mathrm{~mm}$ long, and sericeo-glandular cypselae. See comments under L. amambaia and L. remotiflora. 


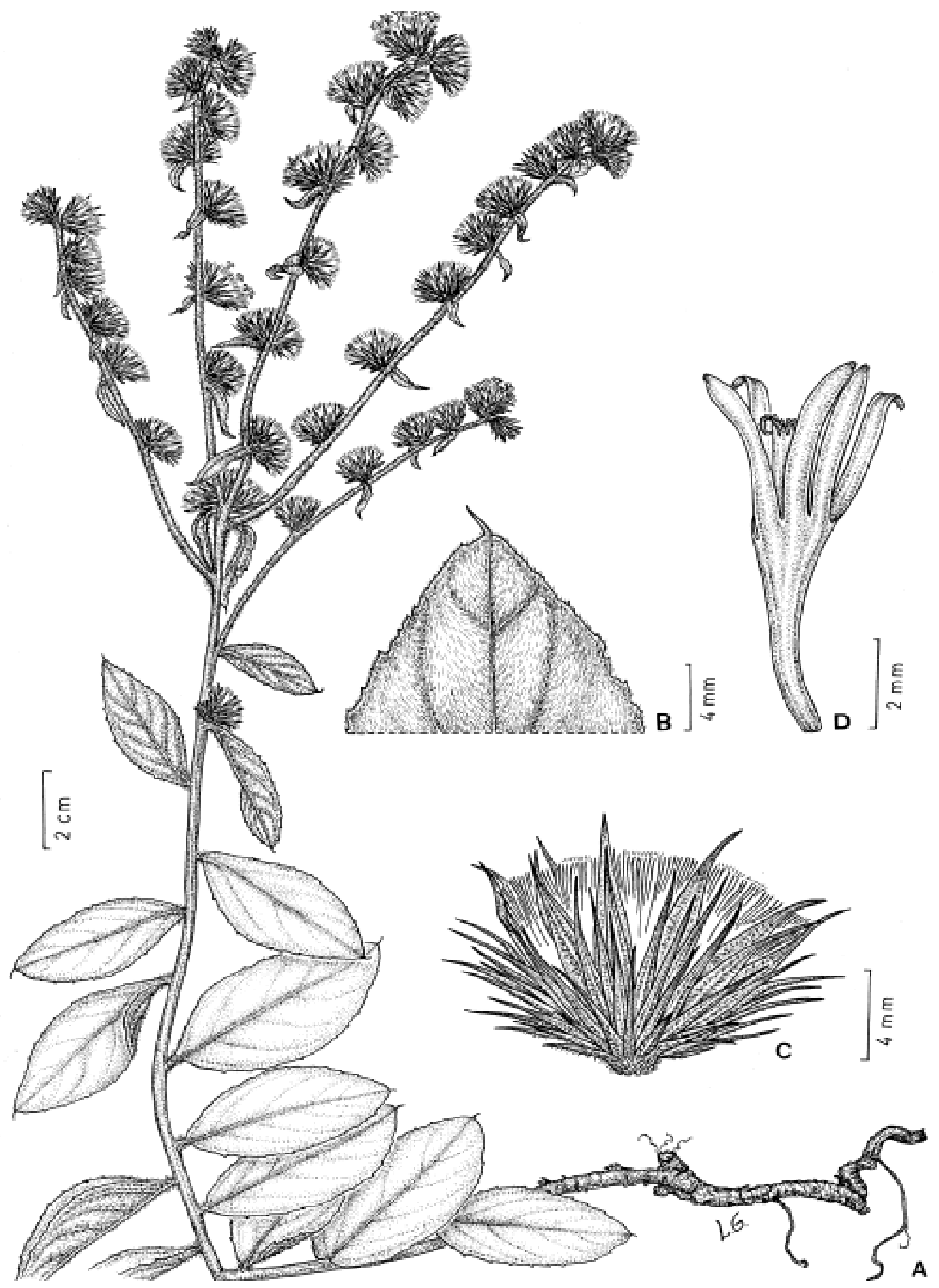

FIGURE 21. Lepidaploa setososquamosa. A. Plant. B. Abaxial leaf surface detail. C. Capitula. D. Floret. Source: Marques \& Dematteis (2014). 
13. Lepidaploa tarijensis (Griseb.) Robinson (1990: 495). Vernonia sericea var. tarijensis Grisebach (1879: 163). Type:-BOLIVIA. Bei Carapari, 19 Juny 1873, P. G. Lorentz 634 (syntypes COND! GOET! [photo!]). Figure 22.

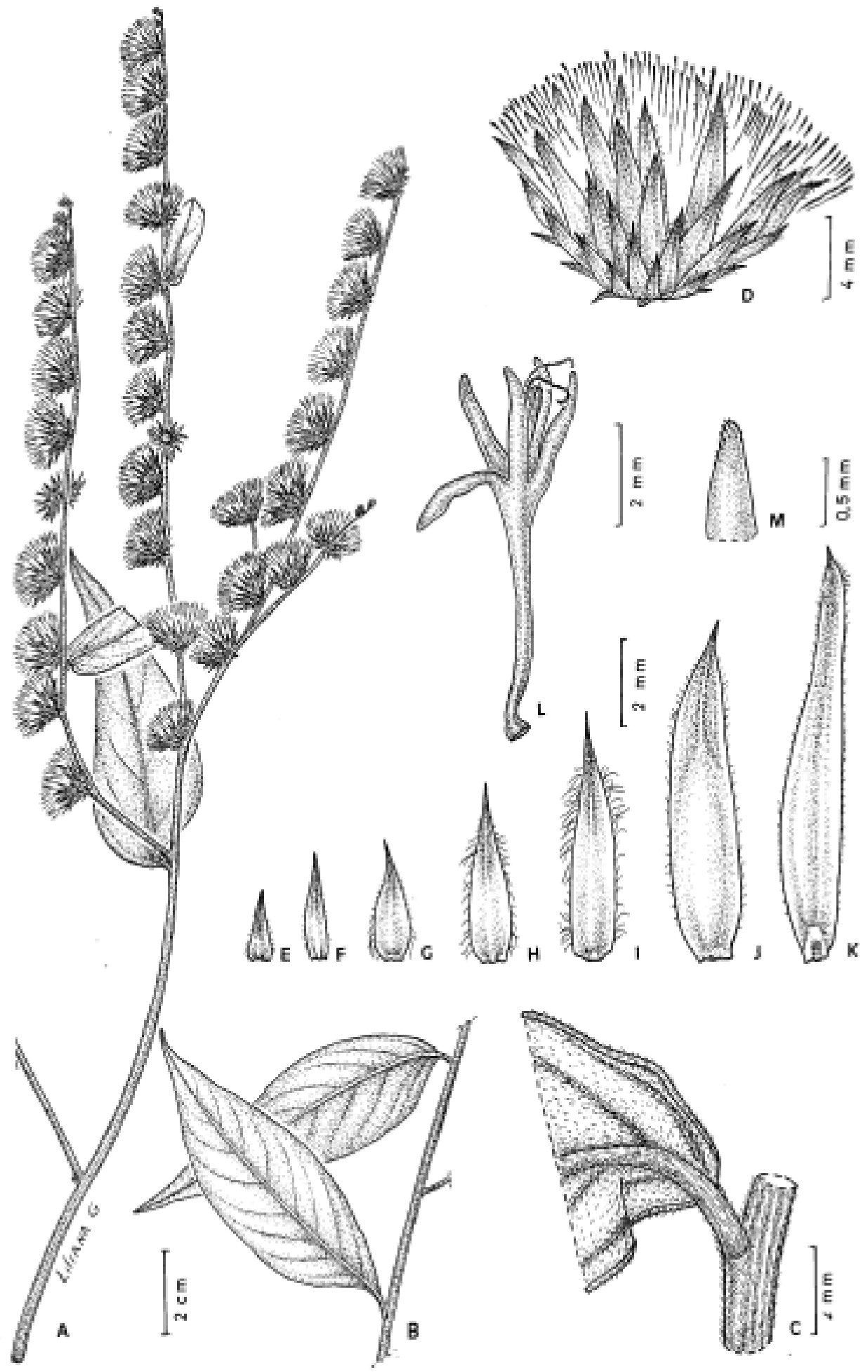

FIGURE 22. Lepidaploa tarijensis. A. Plant. B. Stem and leaf. C. Stem and leaf detail. D. Capitula. E-G. Outer phyllaries. H-K. Inner Phyllaries. L. Floret. M. Corolla lobe detail. Source: Marques \& Dematteis (2014).

Clambering shrubs 1-2 m tall.; branches pubescent. Leaves distichous, cauline, internode $2.2-3.8 \mathrm{~cm}$ long, petioles 3-5 mm long, blade 6.4-8.4 × 1.7-2.7 cm, membranaceous, slightly rugose, ovate-lanceolate, lanceolate, apex acute, margins entire, sometimes sinuate, base attenuate, adaxial surfaces glabrous, abaxial surface pubescent or glabrous; venation camptodromous-eucamptodromous. Capitulescence seriate-cymose with capitula sessile, 3-5.6 cm long, axis densely sericeous, brown to yellowish. Involucre widely campanulate, $8-10 \mathrm{~mm}$ in diam., phyllaries 5-8-seriate, yellowish, scarious, glabrous or pubescent on margins, outer oval-lanceolate, apex apiculate, inner elliptic-lanceolate, 
apex acute or apiculate. Florets 24-27, corolla white or pinkish, tube 4-4.2 mm long, glabrous, lobes 2-2.5 mm long, lanceolate, apex setose; apical anther appendages acute or obtuse, base obtuse; basal stylar node enlarged. Cypsela turbinate, 2-2.3 mm long, sericeous; carpopodium anullar. Pappus white.

Selected specimens examined-ARGENTINA. Salta: General San Martín, camino al Dique Itiyuro, $2 \mathrm{~km}$ de la Ruta 34, 22.IX.1997, M. Dematteis 839 (CTES).

Distribution and habitat - In the study region Lepidaploa tarijensis can be found only in the extreme north of Salta, Argentina. In Salta, the species was found only in the department of General José de San Martín. This species grows on the edges of the North-Central Humid Andes (Figure 20).

Phenology — Collected with flowers from May to August.

Notes-Lepidaploa tarijensis is similar to L. novarae. See comments under L. novarae. In summary, L. tarijensis can be differentiated from the other species of southern South America by the following combination of characters: clambering shrubs, pappus white, involucre $8-10 \mathrm{~mm}$ long, glandular trichomes absent on the corolla lobes, and cypselae without idioblasts.

\section{Acknowledgments}

We are grateful to Mirtha Liliana Gómez for the line drawing of the species and Ercilia María Sara Moreno for helpful suggestions and comments on the manuscript. This work was supported by grants from the Consejo Nacional de Investigaciones Científicas y Técnicas (CONICET).

\section{References}

Anderberg, A.A., Baldwin, B.G., Bayer, R.G., Breitwieser, J., Jeffrey, C., Dillon, M.O., Eldenäs, P., Funk, V., Garcia-Jacas, N., Hind, D.J.N., Karis, P.O., Lack, H.W., Nesom, G.L., Nordenstam, B., Oberprieler, C., Panero, J.L., Puttock, C., Robinson, H., Stuessy, T.F., Susanna, A.. Urtubey, E., Vogt, R., Ward, J. \& Watson, L.E (2007) Compositae. In: Kadereit, J.W. \& Jeffrey, C. (Eds.) Kubitzki’s The families and genera of Vascular Plants. Vol. 8. Springer, Berlin \& Heidelberg, pp. 61-588.

https://doi.org/10.1007/978-3-540-31051-8_7

Angulo, M.B., Vega, A.J. \& Dematteis, M. (2012) Nuevas combinaciones en los géneros sudamericanos Lepidaploa y Lessingianthus (Vernonieae, Asteraceae). Gayana Botánica 69 (2): 267-274.

https://doi.org/10.4067/S0717-66432012000200006

Baker, J.G. (1873) Compositae I. Vernoniaceae. In: Martius, C.F.P. \& Eichler, A.G. (Eds.) Flora brasiliensis. Vol. 6. Pt. 2. Fleischer, Leipzig, pp. 1-179.

Cabrera, A.L. \& Klein, R.M. (1980) Fasciculo Compostas 3: Tribo Vernonieae. In: Reitz, R. (Ed.) Flora Ilustrada Catarinense. Itajaí, pp. 227-408.

Cabrera, A.L. (1997) Una nueva especie de Vernonia (Compositae) del este de Salta (Argentina). Hickenia 2 (54): $255-256$.

Candolle, A.P. de (1836) Prodromus systematis naturalis regni vegetabilis. Vol. 5. Treuttel \& Würtz, Paris, 706 pp.

Cassini, A.H.G. (1817) Aperçu des genres nouveaux formés par M. Henri Cassini dans la familla des Synanthérés. Quatrième fascicule. Bulletin des Sciences de La Sociéte Philomatique de Paris 1817: 66-70.

Cassini, A.H.G (1825) Oliganthe, Oliganthes. In: Cuvier, F.G. (Ed.) Dictionnaire des Sciences Naturelles. Vol. 36. F.G. Levrault, Strasbourg \& Paris, \& Le Normant, Paris, pp. 18-20.

Cristóbal, C.L. \& Dematteis, M. (2003) Asteraceae. XVIII. Tribu I. Vernonieae. In: Hunziker, A.T. (Ed.) Flora Fanerogámica Argentina. Vol. 83. Museo Botánico de Córdoba, Argentina, pp. 3-53.

Dematteis, M. \& Cabrera, A.L. (2009) Vernonieae. In: Ramella, L. \& Perret, P. (Eds.) Flora del Paraguay. Vol. 39: Compositae IV. Conservatoire et Jardin botaniques de la Ville de Genève, Genève, pp. 65-298.

Dematteis, M. \& Almeida, G. (2015) Lepidaploa. In: Lista de Espécies da Flora do Brasil. Jardim Botânico do Rio de Janeiro. Available from: http://floradobrasil.jbrj.gov.br/jabot/floradobrasil/FB16164. (accessed 1 September 2016)

Funk, V.A., Susanna, A., Stuessy, T.F. \& Bayer, R.J. (2009) Systematics, Evolution, and Biogeography of Compositae. Smithsonian Institution, Washington, $965 \mathrm{pp}$.

Gardner, G. (1845) Contributions towards a Flora of Brazil, being the distinctive characters of a century of new species of plants from the Organ Mountains. London Journal of Botany 4: 97-136.

Gardner, G. (1846) Contributions towards a Flora of Brazil, being the distinctive characters of some new species of Compositae, belonging 
to the tribe Vernoniaceae. London Journal of Botany 5: 209-242.

Grisebach, A.H.R. (1879) Symbolae ad Floram Argentinam. Abhandlungen der Königlichen Gesellschaft der Wissenschaften zu Göttingen 24: $1-345$.

Hind, N. (2011) An annotated preliminary Checklist of the Compositae of Bolivia. Version 2. Richmond, Royal Botanical Gardens, Kew, $750 \mathrm{pp}$.

Hieronymus, G.H.E.W. (1897) Erster Beitrag zur Kenntnis der Siphonogamenflora der Argentina und der angrenzenden Länder, besonders von Uruguay, Paraguay, Brasilien und Bolivien. Botanische Jahrbücher für Systematik, Pflanzengeschichte und Pflanzengeographie 22: 672-798.

Keeley, S.C. \& Robinson, H. (2009) Vernonieae. In: Funk, V.A., Susanna, A., Stuessy, T.F. \& Bayer, R.J. (Eds.) Systematics, evolution and biogeography of Compositae. IAPT, Vienna, pp. 439-469.

Lessing, C.F. (1829) Synanthereis Herbarii Regii Berolinensis dissertatio prima. Linnaea 4: 289-356.

Marques, D. \& Dematteis, M. (2014) Lepidaploa (Cass.) Cass. In: Zuloaga, F.O., Belgrano, M.J. \& Anton, A.M. (Eds.) Flora Argentina, Flora Vascular de la República Argentina. Vol. 7. Dicotyledoneae, Asteraceae: Senecio a Vernonieae. IBODA CONICET, Argentina, pp. 243-249.

Moreira-Muñoz, A. (2011) Plant Geography of Chile. Springer, New York, 320 pp. https://doi.org/10.1007/978-90-481-8748-5

Myers, N., Mittermeier, R.A., Mittermeier, C.G., Fonseca, G.A.B. \& Kent, J. (2000) Biodiversity hotspots for conservation priorities. Nature 403: 853-858. https://doi.org/10.1038/35002501

Newton, A.C. \& Tejedor, N. (2011) Principles and Practice of Forest Landscape Restoration. IUCN, Gland, Switzerland, 383 pp.

Panero, J.L., Freire, S.E., Espinar, L.A., Crozier, B.S., Barboza, G.E. \& Cantero, J.J. (2014) Resolution of deep nodes yields an improved backbone phylogeny and a new basal lineage to study early evolution of Asteraceae. Molecular Phylogenetics and Evolution 80: $43-53$. https://doi.org/10.1016/j.ympev.2014.07.012

Pruski, L.B. (1998) Compositae of the Guayana Highland XIII. New combinations in Conyza (Astereae), Praxelis (Eupatorieae), and Riencourtia (Heliantheae) based on names proposed by L.C.M. Richard. Britonnia 50: 473-482. https://doi.org/10.2307/2807757

Radford, A. (1986) Fundamentals of plant systematics. Harper \& Row, New York, 498 pp.

Redonda-Martínez, R. \& Villaseñor, J.L. (2011) El género Lepidaploa (Familia Asteraceae, Tribu Vernonieae) en México. Revista Mexicana de Biodiversidad 82: 782-797.

Richard, L.C.M. (1792) Catalogus Plantarum, ad Societatem, ineunte anno 1792, e Cayenna missarum a Domino le Blond. Actes de la Société d'Histoire Naturelle de Paris 1: 105-114.

Robinson, H. (1990) Studies in the Lepidaploa complex (Vernonieae: Asteraceae). VII. The genus Lepidaploa. Proceedings of the Biological Society of Washington 103 (2): 464-498.

Robinson, H. (1994) New combinations in American Vernonieae (Asteraceae). Phytologia 76 (1): $27-29$.

Robinson, H. (1995) New combination and new species in American Vernonieae (Asteraceae). Phytologia 78 (5): $384-399$. https://doi.org/10.5962/bhl.part.10065

Robinson, H. (1998) Two new species of Lepidaploa (Vernonieae: Asteraceae). Phytologia 84 (1): 40-42. https://doi.org/10.5962/bhl.part.17403

Robinson, H. (1999) Generic and subtribal classification of American Vernonieae. Smithsonian Contributions to Botany 89: 1-116. https://doi.org/10.5479/si.0081024X.89

Robinson, H., Bohlmann, F. \& King, R.M. (1980) Chemosystematic notes on the Asteraceae. III. Natural subdivisions of the Vernonieae. Phytologia 46: 421-436.

https://doi.org/10.5962/bhl.part.14735

Zuloaga, F.O., Morrone, O. \& Belgrano, M.J. (2008) Catálogo de Plantas Vasculares del Cono Sur, vol. 1. Monographs in Systematic Botany from the Missouri Botanical Garden 107: 1-3348. 
Appendix I. Collectors List

Abrão, H.R.S. 84 (3); Adenesky, E. FURB 4542 (3); Aguayo, A. 526 (3); Ahumada, O. 8177 (7), 8365 (7); Angulo, M.B. 20 (10); Arbo, M.M. 5933 (3), 8866 (10), 8993 (12), 9227 (10); Arzivenco, L. 44336 (8); 48496 (3); Azevedo, T.I.N. 530 (3); Baptista, L. ICN 25533 (3); Barbero, A. 313 (10); Barbosa, E. 700 (6), 1012 (2), 3674 (1); Barboza, G. 503 (10); Basualdo, I. 2224 (10), 2544(3), 3500 (3); Bertoni, M.S. 2879 (3), 3677 (3); Bianek, A.E. 150 (4); Bordas, E. 1014 (10), 1251 (10), 1593 (10), 1835 (10), 3612 (10); Bordón, A.O. 230 (4), $340(4), 372$ (4), 644 (4); Bresolin, A. 313 (6); Broto M.L. 1723(6); Bueno, O. 1032 (3); 1200 (8); Cabral, E. 348 (9); Camargo, O. PACA 63650 (3), 1471 (3); Carnevali, R. 507 (3), 5471 (10), 5638 (10), 5639 (10); Carneiro, J. MBM 164945 (4), 482 (3), 1432 (3); Carriz, B. RB 57451 (4); Caxambú, M.G. 518 (3); Cervi, A. 526 (3), Cordeiro, J. 1554 (6); Correa, M.N. 7909 (3), 7949 (3); Cowan, C.P. 4157 (10); Cristóbal, C.L. 1744 (3); Crovetto, M. 237 (3), 679 (4), 11357 (3); Degen, R. 483 (10), 636 (10), 1488 (3), 1606 (3), 3298 (12); Deble, L.P. 12020 (9); Dematteis, M. 273 (10), 311 (10), 477 (10), 514 (10), 839 (13), 867 (1), 2646 (10), 3047 (9), 3336 (1), 4139 (9); Dreveck, S. 1826 (8), 2315 (4); Duarte, A.P. 5269 (3); Dziewa, A. 66 (6), 85 (6); Egea, J. 1213 (10); Eggers, L. ICN 84025 (4); Falkenberg, D.B. 2530 (6), 2604 (6), 2612 (6), 4364 (6), 6127 (4); Ferrari, M.V. 1202 (3); Ferrucci, M.S. 2821 (10); Fleigi, M. 38 (8); Fravo, A. 13 (4); Funez, L.A. 1928 (4); Gaelzer, M.B. 65 (7), 82 (3), 99 (8), 1979 (3); Gasper, A.L. 1418 (8), $1495(8), 1574$ (8), 1606 (8); Geraldino, H.C.L. 104 (3); González, F. 256 (3), 1323 (10); Grazziotin, G. 260 (3); Guimarães, T.B. 530 (4), 544 (4); Hagelund, K. 1045 (3), 3781 (3), 13118 (8); Hahn, W. 2457 (10); Hatschbach, G. 4032 (3), 6144 (6), 7268 (3), 7528 (4), 8845 (10), 8848 (4),14523 (6), 16529 (3), 24258 (3), 29372 (4), 32304 (3), 41438 (8), 43889 (11), 48084 (3), 49535 (6), 51930 (4), 54444 (6), 55471 (5) 61081 (3), 68293 (11), 69264 (3), 71841 (4), 78291 (8), 78959 (8), 79080 (10), 79126 (4), 79137 (3), 79554 (8), 79695 (8), 79077 (8), 79109 (8), 79121 (8), 79766 (8), 79833 (8), 79945 (3); Hauman 4497 (3); Hentschel, R. ICN 157942 (4); Henz, E. PACA 27631 (3); Herrera, J. 357 (10); Hilgert, N. 425 (10); Hunziker, A.T. 5373 (4); Imaguire, N. 2789 (8); Jarenkow, J.A. 83 (3), 715 (3), 888 (3), 1689 (3), 2526 (3), 3119 (3); Jiménez, B. 1408 (3); Kell, S. 1509 (3); Keller, H.A. 280 (3), 1112 (3), 1778 (10), 2070 (10), 3106 (3), 3518 (10), 3921 (7), 4096 (10), 4268 (10), 4788 (10), 4828 (10), 5533 (3), 5590 (10), 5868 (10), 6416 (10), 6448 (9), 7036 (8), 8792 (3); Klein, R.M. 5426 (6); 5435 (3), 5446 (3), 5552 (3), 5650 (3), 5726 (3), 6639 (8), 7200 (4), 10647 (5); 10895 (5); Korte, A. 1624 (8), 1745 (8), 1851 (7), 4010 (5), 5917 (8); Krapovickas, A. 12152 (10), 12228 (10), 13086 (10), 13948 (10), 13886 (10), 13948 (10), 15932 (3), 18183 (10), 19452 (13), 24912 (10), 25011 (10), 25552 (3), 26236 (3), 28674 (9), 29153 (10), 33613 (8), 37727 (4), 38426 (4), 41886 (10), 44154 (10), 44197 (12), 44450 (10), 44612 (9), , 45131 (3), 45468 (12), 46296 (12), 47264 (13); Kummrow, R. 3077 (6); Kuniyoshi, Y.S. 4994 (6); Kurtz, F. 08 (10); Layzon, A.S. RB (650076) (4); López, M.G. 257 (10); Loureiro, M.L. 750 (6); Lurvey, E. 56514 (10); Marmoni, G.C. 410 (3); Maruñak, V. 963 (10); Mereles, F. 5040 (12), 5042 (12), 7717 (3), 8484 (10); Miranda, D. 77 (3); Molero, J. 09 (10); Mondih, C. 813 (8); Montes, J.E. 2142 (3), 15428 (3), 15837 (3); Motta, J.T. 881 (3); Nicolack, V. 133 (6); Novara, L.J. 10877 (12); Nuember, A. 48 (4); Ortíz, M. 235 (3); 423 (10); Pasini, E. 333 (8); Paul, M.R. 21 (10); Paula-Souza, J. 7260 (10); Pedersen, T.M. 15918 (8); Peña-Chocarro, M. 2210 (10), 2594 (10); Pérez, L. 442 (3); Piccinini, B. 3607 (10); Ponciano, J. MBM 78551 (3); Queiroz, M.H. 259 (6); Rambo, B. PACA 30993 (3), PACA 41850 (3), PACA 42001 (3), PACA 42105 (3), PACA 42229 (3), PACA 42361 (3), PACA 42507 (3), PACA 47236 (3), 1872 (3), 42246 (3), 42299 (3), 47924 (3); Raw 10 (3); Recalde, A. 07 (10); Reitz, R. HBR 44149 (3), 881 (6), 3973 (6), 4581 (4); 6521 (8), 6588 (8), 10614 (8), 10742 (8), 10895 (5); Ribas, O.S. 3331 (8), 6789 (8), 7222 (8), 7987 (4); Rinnert, C.H. 308 (4); Ritter, M.R. 650 (3); Rodriguez, F.M. 92 (10); Rodriguez, M. 745 (3); Rossato, M. 69 (8); Santos, P.R. MBM 330618 (3); Schinini, A.G. 2728 (4), 3035 (9), 4907 (3), 5039 (10), 5138 (13), 6799 (3), 8006 (10), 8203 (4), 11209 (10), 15251 (4), 15855 (4), 16585 (4), 16921 (4), 16950 (4), 17190 (4), 18119 (4), 1999 (4), 22903 (1), 27052 (3), 27817 (10), 28740 (3), 30441 (10), 30472 (10), 30545 (10), 31553 (10), 32688 (10), 33245 (10), 33467 (1), 36303 (1); Schmeda,G. 55 (4); Schulz, A. 16950 (4); Schwarz, G.J. 8001 (3); Schwindt, E. 745 (3); Seger, G.D. 187 (3), 214 (3), 482 (3), 609 (3); Sehnem, A. 2866 (3); Silva, F.C. 709 (6); Silva, J.M. 1354 (6), 1726 (6), 5007 (6); Silva, J.M. 5871 (3); Smith, L.B. 7605 (3), 12289 (3); Sobral, M. MBM 78288 (3), 325 (3), 8188 (3); Soria, N. 429 (10), 717 (10), 1513 (10), 1579 (3), 1599 (3), 2047 (1), 2050 (10), 3165 (10), 3244 (10), 4004 (3), 6044 (1), 6113(1); Stival-Santos, A. 785 (6), 1984 (4), 2022 (4); Rojas, T. 634 (10), 2877 (10), 13252 (10); Tomé, M.F.V. 874 (4); Torri, M.E. 26 (10), 298 (10), 306 (10); Tortosa, M. 59 (3); Tressens, M.A. 7067 (4); Tressens, S.G. 3936 (10), 5243 (10), 5623 (3), 5649 (3), 6385 (3), 6710 (10); Vadulga, E. 81 (3); Vanni, R. 445 (4), 753 (3), 766 (10), 827 (3), 910 (3), 956 (3), 1044 (9), 2476 (12), 2703 (3), 2727 (3), 4557 (10); Vera, M. 2733 (10), 3219 (12); Verdi, M. 3809 (8), 4028 (4), 4494 (4), 5499 (6), 5909 (8); Vervoorst, B. 4581 (7); Waechter, J.A. 228 (8); Wasum, R. MBM 234353 (3); 1772 (3); 2157 (3), 2481 (8); Zanin, A. 966 (8), 1023 (8), 1033 (8); Zardinini, E. 3101 (10), 3841 (10), 4287 (10), 4938 (3), 9478 (10), $9486(10), 9585$ (10), . 9801 (3), 9875 (10), 10041 (10), 10685 (10), 11111 (10), 11570 (10), 12338 (3), 13375 (10), 13467 (3), 14041 (3), 14122 (3), 14711 (3), 14884 (10), 14889 (10), 14967 (3), 26127 (10), 26212 (10), 26690 (10), 27064 (10). 
https://doi.org/10.11646/phytotaxa.362.2.1

\title{
The genus Lepidaploa (Vernonieae, Asteraceae) in southern South America
}

\author{
DANILO MARQUES ${ }^{1}$, GABRIELA ELIZABETH FARCO², JIMI NAOKI NAKAJIMA ${ }^{3}$ \& MASSIMILIANO \\ DEMATTEIS ${ }^{4}$ \\ ${ }^{1}$ Instituto de Botánica del Nordeste (UNNE-CONICET), Casilla de Correo 209, CP 3400 Corrientes, Argentina. \\ E-mail: danilobioufu@gmail.com \\ ${ }_{2}^{2}$ Instituto de Botánica del Nordeste (UNNE-CONICET), Casilla de Correo 209, CP 3400 Corrientes, Argentina. \\ E-mail: gabyfarco@hotmail.com \\ ${ }^{3}$ Universidade Federal de Uberlândia, Instituto de Biologia, Programa de Pós-graduação em Biologia Vegetal, Campus Umuarama, \\ Bloco 2D, 38.400-902 Uberlândia, Minas Gerais, Brasil.E-mail: nakajima@ufu.br \\ ${ }_{4}^{4}$ Instituto de Botánica del Nordeste (UNNE-CONICET), Casilla de Correo 209, CP 3400 Corrientes, Argentina. \\ E-mail:mdematteis@agr.unne.edu.ar
}

\begin{abstract}
A morphological analysis of the genus Lepidaploa (Vernonieae) of southern South America has been carried out. Until now, the information concerning the genus was fragmented and incomplete for this region. Altogether, 13 species are described and illustrated here. A comprehensive key to the species of southern South America is presented; in addition, we characterized and delimited the distributions of the species.
\end{abstract}

Key words: South America, Compositae, flora, taxonomic treatment

\section{Introduction}

Asteraceae is one of the most important and representative Angiosperm families in the world, covering 24,000 species (Funk et al. 2009). The family inhabits temperate, tropical, mountainous, dry and open environments (Anderberg et al. 2007). Asteraceae is considered a monophyletic family that presents several morphological and molecular synapomorphies (Funk et al. 2009). Asteraceae comprises 13 subfamilies and 44 tribes (Panero et al. 2014), with Eupatorieae and Vernonieae among the greatest in the number of species (Funk et al. 2009).

The tribe Vernonieae has a pantropical distribution and is composed of 126 genera and 1,500 species, being the fifth tribe in Asteraceae with the highest number of species (Keeley \& Robinson 2009). In a series of studies in Vernonieae, Robinson (1999) substantially altered the traditional circumscription of Vernonia sensu lato, fragmenting it into several genera, as e.g. Lepidaploa Cassini (1817: 66) Cassini (1825: 20).

Currently, Lepidaploa is the largest genus of the tribe and has around 140-150 species (Funk et al. 2009, Angulo et al. 2012). Plants of this genus are characterized by presenting small capitula grouped in cymose inflorescences, commonly eglandular anther apical appendages, basal stylar node present, usually eglandular cypselae and pollen of types C, D or G (Robinson 1990, 1999).

The genus Lepidaploa is distributed from Mexico to northeast of Argentina (Redonda-Martínez \& Villaseñor 2011, Marques \& Dematteis 2014). Brazil is a country with the greatest diversity of its species, 51 in total (Dematteis \& Almeida 2015). This country is followed by Bolivia with 27 species (Hind 2011), and Venezuela and Cuba with 16 species each (Redonda-Martínez \& Villaseñor 2011). In southern South America, Lepidaploa is distributed in Paraguay (Dematteis \& Cabrera 2009), south of Brazil (Dematteis \& Almeida 2015), and north and northeast of Argentina (Marques \& Dematteis 2014). However, the genus occurs neither in Chile (Moreira-Muñoz 2011) nor in Uruguay.

Due to the importance of a taxonomic treatment of the genus Lepidaploa in southern South America, here we present an identification key, descriptions, illustrations and geographical distributions, discussing the affinities between the species. 


\section{Material and Methods}

Southern South America is the area constituted by Argentina, Chile, Paraguay, Uruguay and southern Brazil (Paraná, Santa Catarina and Rio Grande do Sul states) (Zuloaga et al. 2008). The area lies between $48^{\circ}-75^{\circ} \mathrm{N}$ and $17^{\circ} 30^{\prime}-$ $56^{\circ} 30^{\prime} \mathrm{S}$ and comprises about $4,708,617 \mathrm{~km}^{2}$, representing about $26 \%$ of the entire territory of South America (Zuloaga et al. 2008). This area has a great variety of biogeographic regions with peculiar characteristics, which causes a great floristic diversity (Zuloaga et al. 2008). In total, 11 biogeographic regions are included in southern South America: North-Central Humid Andes, South-Central Dry Andes, Atlantic Forest, Cerrado, Chilean-Peruvian Desert, Chile Mediterranean, Chaco, Pampas, Monte, Patagonia and Pacific Temperate Humid (Zuloaga et al. 2008). Among these biogeographic regions, five are included within hotspots: North-Central Humid Andes, South-Central Dry Andes, Mediterranean Chile, Cerrado and Atlantic Forest (Myers et al. 2000; Newtow \& Tejedor 2011).

Southern South America has a great number of species (both native and introduced), with 17,693 species grouped in 2,586 genera and 308 families (Zuloaga et al. 2008). A total of 249 genera are endemic to southern South America. Regarding species, 7,691 are endemic to southern South America, representing $43.47 \%$ of the total species diversity in the area (Zuloaga et al. 2008). In this region, the family with the highest number of endemic representatives is Asteraceae (Zuloaga et al. 2008).

The study of the species was made based on material from the following herbaria: CTES, FCQ, FLOR, FURB, HBR, ICN, MBM, MVFA, PACA, RB and SCP. Only one herborized specimen of each province or state, in which the species occur, is listed as selected specimens examined. For the examined material the location, date, collector(s) and collector number(s) are cited. In addition, all the material examined in this work is included in a list of collectors. When the material from the area could not be consulted in the herbarium, as happened for example with L. decumbens, material from other states was used for the species description. For the habitat (biogeographic region), the terminology used was based in Zuloaga et al. (2008). For each species are mentioned the provinces or states of occurrence of plants both inside and outside southern South America. The distribution map was made in QGIS version 2.18.9 with GRASS 2.2.1. The terminology used in descriptions follows Radford (1986) and Dematteis \& Cabrera (2009). The collectors list can be found in Appendix I.

\section{Taxonomic treatment}

Lepidaploa includes 13 species occurring in southern South America, of which two are endemic to the area (L. novarae and $L$. pseudomuricata). However, most of the species described in this study are endemic to South America, except L. remotiflora and L. salzmannii which are distributed from Mexico to Argentina (Redonda-Martínez \& Villaseñor 2011). In terms of distribution, L. argyrotricha occurs exclusively in Brazil (Dematteis \& Almeida 2015), while $L$. eriolepis grows in Brazil and Bolivia (Hind 2011; Dematteis \& Almeida 2015). Lepidaploa amambaia is restricted to Paraguay and Mato Grosso do Sul in Brazil (Dematteis \& Cabrera 2009, Dematteis \& Almeida 2015). On the other hand, L. balansae occurs in Argentina, Paraguay and in the southern states and in the state of São Paulo in Brazil (Dematteis \& Cabrera 2009, Marques \& Dematteis 2014, Dematteis \& Almeida 2015). Lepidaploa chamissonis and L. psilostachya occur exclusively in Argentina and Brazil (Marques \& Dematteis 2014, Dematteis \& Almeida 2015), while L. setososquamosa is distributed in Argentina, Bolivia and Paraguay (Dematteis \& Cabrera 2009, Hind 2011, Marques \& Dematteis 2014). Most of these species are present in biodiversity hotspots (Cerrado, Atlantic Forest or North-Central Humid Andes).

The species of Lepidaploa in southern South America are restricted to Argentina, Paraguay and southern Brazil. Although in Argentina the genus is distributed in the north and northeast, Lepidaploa is not found in Chile and Uruguay, probably due to climatic differences. Among geopolitical regions, southern Brazil is the area of southern South America that presented the largest number of species. In total, nine species of Lepidaploa were found in this Brazilian region. Argentina is the second country in southern South America with the highest number of species of Lepidaploa (eight species), followed by Paraguay that has four or five species, considering that $L$. salzmannii also occurs in Paraguay as reported by Dematteis \& Cabrera (2009). 
Lepidaploa (Cassini) Cassini (1825: 20). Vernonia subgen. Lepidaploa Cassini (1817: 66).

Type (designated by Robinson et al. (1980: 428)): Vernonia albicaulis Persoon [= Lepidaploa glabra (Willdenow) H. Rob.]

Herbs, subshrubs or erect shrubs, rarely clambering (L. balansae, L. novarae and L. tarijensis). Branches strigose, strigosetomentose, pubescent, sericeous, setose or velutinous. Leaves distichous, rarely spirally alternate (L. pseudomuricata), cauline or rarely basal and cauline (L. psilostachya), petiolate or sessile; blade membranous, chartaceous, membranouscoriaceous, smooth or rugose, elliptic, elliptic-lanceolate, lanceolate, linear-lanceolate, oblong-lanceolate, ovallanceolate, oval, ovate-lanceolate, apex apiculate, acute, caudate, margins entire or denticulate, rarely serrulate, sinuate or revolute (L. balansae, L. decumbens and L. psilostachya), base attenuate, cuneate, adaxial surface strigose, strigosetomentose, glabrous, pubescent, abaxial surface strigose, glabrous, incanous, pubescent, tomentose, velutinous, venation brochidodromous, camptodromous, camptodromous-eucamptodromous, eucamptodromous, eucamptodromousbrochidodromous, eucamptodromous-reticulodromous. Capitulescence seriate-cymose with capitula sessile, rarely paniculiform; axis strigose-tomentose, glabrous or glabrescent, tomentose-velutinous, velutinous, villous, whitish, gold, ferruginous, gray, brown, green or yellowish-green. Involucre campanulate, rarely turbinate (L. balansae); phyllaries 4-6-seriate, yellowish, chestnut, brown, reddish, greenish, greenish with blackened apex, scarious, membranaceous, strigose, strigose-tomentose, glabrous, pubescente, tomentose, villous; outer elliptic-lanceolate, linear-lanceolate, ovate, oval-lanceolate, apex apiculate, rarely aristate (L. setososquamosa) or apiculate-recurved ( $L$. decumbens); inner elliptic-lanceolate, lanceolate, apex acute, acute-apiculate, apiculate, rarely aristate ( $L$. setososquamosa) or apiculaterecurved ( $L$. decumbens), obtuse to rotund. Florets 10-40, corolla white, lilac, pink, violet, tube glabrous, lobes lanceolate, apex glandular, setose or setose-glandular; apical anther appendages acute, obovate or obtuse, rarely with glandular trichomes (L. pseudomuricata), base obtuse or sagittate; basal stylar node enlarged, rarely narrow (L. balansae and L. pseudomuricata). Cypsela turbinate, obconic, velutinous, setose, sericeous-glandular (L. setososquamosa); carpopodium annular, idioblasts lacking or present. Pappus 2-seriate, white or beige, rarely grayish, brown or chestnut (L. novarae, L. balansae and L. eriolepis).

\section{Key to species of Lepidaploa of southern South America}

1. Clambering shrubs 2

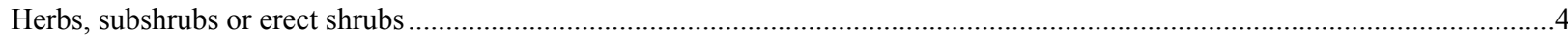

2. Venation brochidodromous; pappus brown; heads with 10-12 florets; involucre turbinate; basal stylar node narrow; species widely

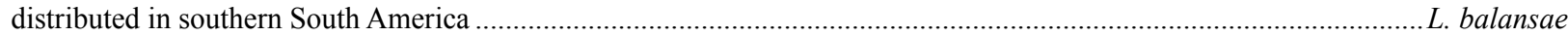
Venation camptodromous-eucamptodromous; pappus whitish; heads with 20-27 florets; involucre campanulate; basal stylar node enlarged; species restricted to the province of Salta.

3. Involucre 6-7 $\mathrm{mm}$ in diam.; glandular trichomes present on corolla lobes; cypselae with idioblasts ......

- Involucre 8-10 mm in diam.; glandular trichomes absent on corolla lobes; cypselae without idioblasts Branches prominently ribbed; anther appendages with glandular trichomes; basal stylar node narrow Branches not ribbed or slightly ribbed; anther appendages without glandular trichomes; basal stylar node enlarged Heads with 35-40 florets; branches, inflorescences, leaves and phyllaries strigose-tomentose; pappus nut-brown........ L. eriolepis Heads with 15-25 florets; branches, inflorescences, leaves and phyllaries glabrescent, pubescent, setulose, strigose, tomentose, velutinous or villous; pappus white or beige

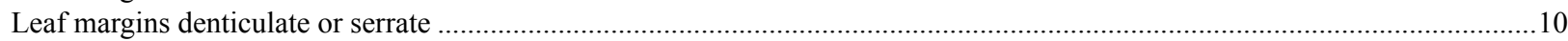

7. Leaves with petiole 13.5-14 mm long; corolla lobes without glandular trichomes........................................... L. argyrotricha Leaves with petiole $0.3-7 \mathrm{~mm}$ long or sessile; corolla lobes with glandular trichomes ...........................................................

8. Leaf blade ovate, oval-lanceolate, ovate-lanceolate; leaves with petioles 3-7 mm long.......................................... chamissonis

- $\quad$ Leaf blade lanceolate; leaves sessile or on petioles $0.3-0.4 \mathrm{~mm}$ long

9. Leaf margins revolute, adaxial surface strigose; inflorescence 1.6-3.6 cm long; phyllaries with apex apiculate-recurved.

L. decumbens Leaf margins plane, adaxial surface tomentose; inflorescence 12-13.2 cm long; phyllaries with apex apiculate-recurved .

L. salzmannii

10. Leaves basal and cauline; venation camptodromous................................................................................ L. psilostachya

- $\quad$ Leaves only cauline; venation eucamptodromous-brochidodromous or eucamptodromous-reticulodromous................................11

11. Leaf apex acute, venation eucamptodromous-reticulodromous; inner phyllaries with apex acute; glandular trichomes present on corolla lobes and style branches ............................................................................................................. L. remotiflora Leaf apex apiculate, venation eucamptodromous-brochidodromous; inner phyllaries with apex apiculate or aristate; glandular trichomes absent on corolla lobes and style braches ................................................................................................... 12

12. Leaves with petiole 1.5-2.6 mm long; heads with 17-18 florets; involucre 8-10 mm long; cypselae velutinous.........L. amambaia Leaves sessile; heads with 23-25 florets; involucre 12-14 mm long; cypselae sericeous-glandular .................. L. setososquamosa 
1. Lepidaploa amambaia Robinson (1998: 40).

Type:-BRAZIL. Mato Grosso do Sul state, Rod. MT 642, “20 km de Amambai', 16 December 1983, G. Hatschbach \& L. Callejas 47289 (holotype MBM! [photo!]; isotype US! [photo!]). Figure 1

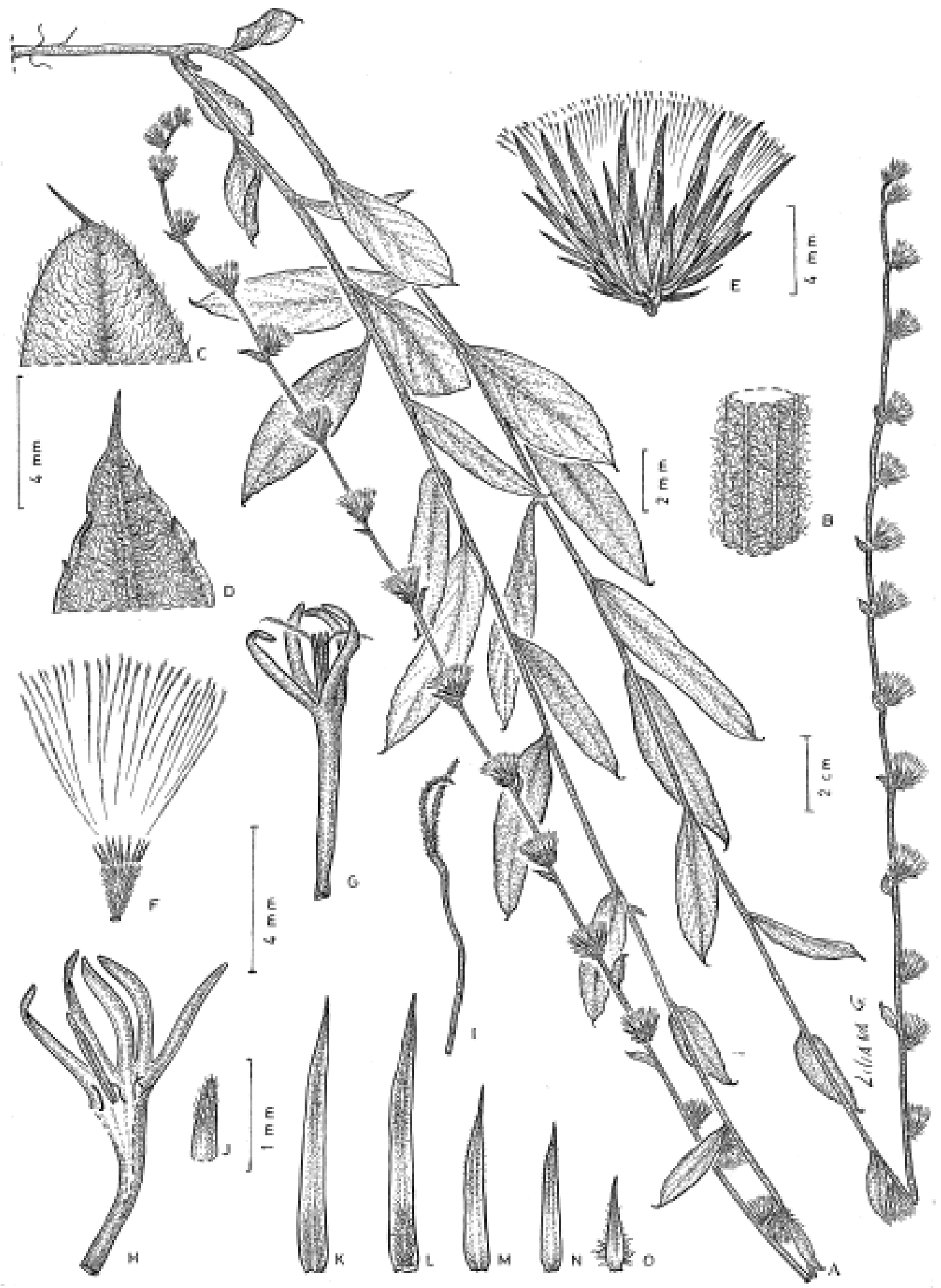

FIGURE 1. Lepidaploa amambaia. A. Plant. B. Stem detail. C. Abaxial leaf surface detail. D. Abaxial leaf surface detail. E. Capitula. F. Cypsela and pappus. G. Floret. H. Floret dissected with anther detail. I. Style. J. Corolla lobe detail. K-M. Inner phyllaries. N-O. Outer phyllaries.

Herbs or erect subshrubs $0.4-0.7 \mathrm{~m}$ tall; branches strigose-tomentose, slightly ribbed. Leaves distichous, cauline, internodes 2.4-2.8 cm long, petioles 1.5-2.6 mm long; blade 3.5-5.3 × 0.7-1.9 cm, chartaceous, smooth, ovatelanceolate or elliptic-lanceolate, apex largely apiculate, margins denticulate, base attenuate to cuneate, both surfaces strigose; venation eucamptodromous-brochidodromous. Capitulescence seriate-cymose with capitula sessile, 8.3- 
$17.4 \mathrm{~cm}$ long, axis strigose-tomentose, green or whitish. Involucre largely campanulate, 8-10 $\mathrm{mm}$ in diam., phyllaries 5-6-seriate, chestnut, greenish, membranaceous, strigose, outer elliptic-lanceolate, apex apiculate, inner lanceolate, apex apiculate. Florets 17-18, corolla violet, tube 4-6 mm long, glabrous, lobes 2.5-3 mm long, lanceolate, apex setose; apical anther appendages obtuse, base obtuse; basal stylar node enlarged. Cypsela turbinate to obconic, 1.5-2 mm long, velutinous; carpopodium annular. Pappus white.

Selected specimens examined-PARAGUAY. Amambay: $25 \mathrm{~km} \mathrm{~N}$ of J. P. Caballero, 10 December 1997, M. Dematteis \& A. Schinini 867 (CTES). Caaguazú: Fazenda La Esmeralda, 11 December 1982, A. Schinini s.n. (CTES 22903). Central: Limpio, 13 March 1985, E. Bordas 3674 (CTES). Concepción: $25 \mathrm{~km}$ of San Carlos from Apa, Estancia Arrecifes, 06 March 2009, M. Dematteis 3336 (CTES, FCQ).

Distribution and habitat - In southern South America this species occurs only in the departments Amambay, Caaguazú, Central and Concepción in Paraguay. According to Dematteis \& Cabrera (2009), L. amambaia also occurs in the department Canindeyú, Paraguay. It was found on fields of Cerrado (Figure 2).

Phenology — Collected with flowers and fruits between December and March.

Notes - It is similar to L. psilostachya, L. remotiflora and L. setososquamosa which also occur in southern South America. Lepidaploa amambaia can de differentiated from L. psilostachya by its usually greater size, 0.4-0.7 (versus 0.3-0.45) $\mathrm{m}$ tall, leaves present only on the stem (versus at the base and on the stem), leaf apex long apiculate (versus acute) and venation eucamptodromous-brochidodromous (versus camptodromous). In turn, L. amambaia differs from L. remotiflora by the apiculate (versus acute) apex of its leaves, a smaller (17-18 versus 21-23) number of florets and the absence (versus presence) of glandular trichomes on the style branches and corolla lobes. Finally, L. amambaia is distinguished from L. setososquamosa by 17-18 (versus 23-25) florets per head, involucre 8-10 (versus 14-15) $\mathrm{mm}$ long, petiolate leaves (versus sessile) and velutinous cypselae (versus sericeous-glandular).

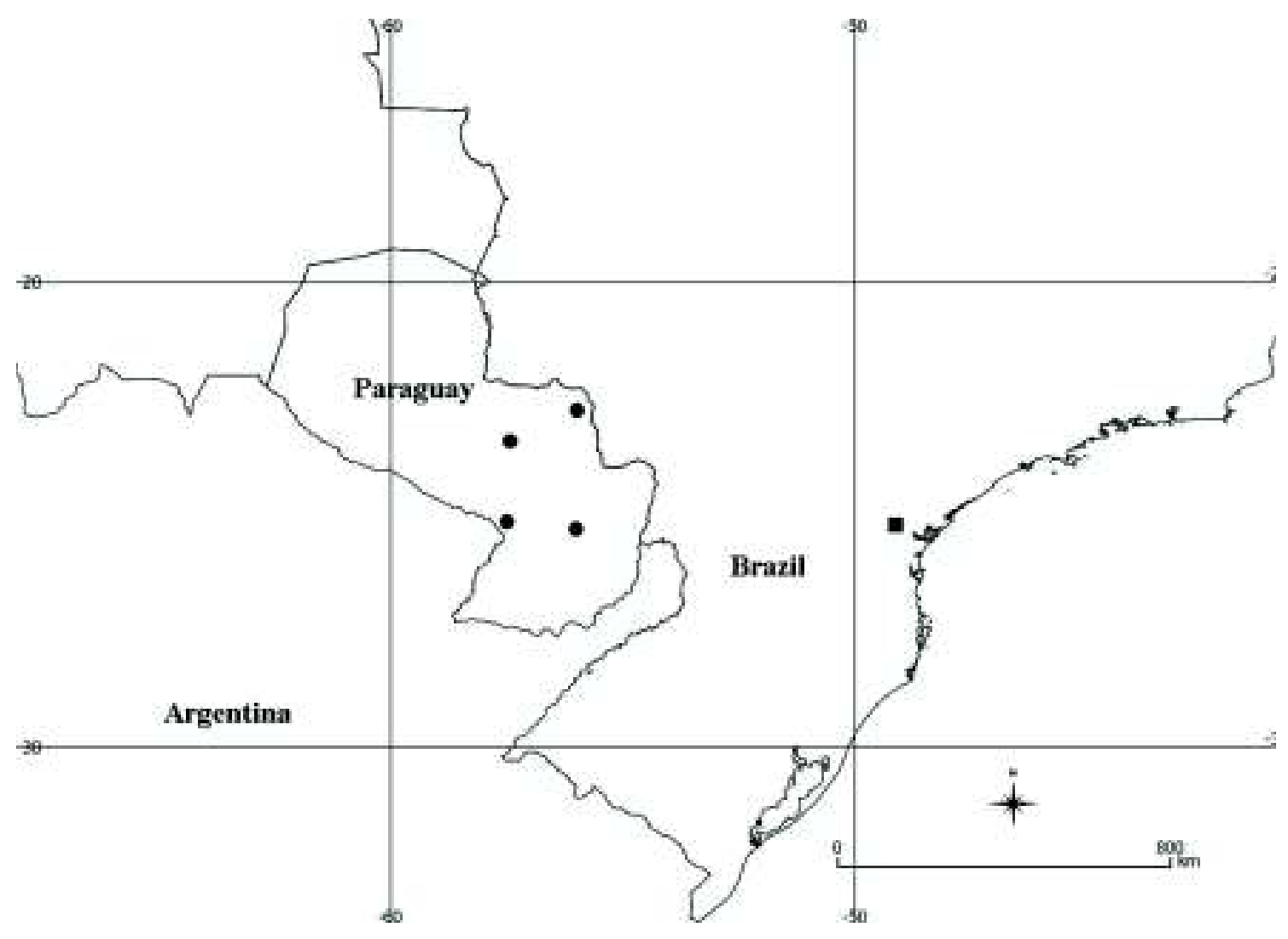

FIGURE 2. Geographical distribution of L. amambaia (circle) and L. argyrotricha (square) in Cone Sur. 
2. Lepidaploa argyrotricha (Sch. Bip. ex Baker) Robinson (1990: 482). Vernonia argyrotricha Sch. Bip. ex Baker (1873: 96).

Type:-BRAZIL. Without locality, F. Sello 1153 (syntype P! [online image!]). Figure 3.

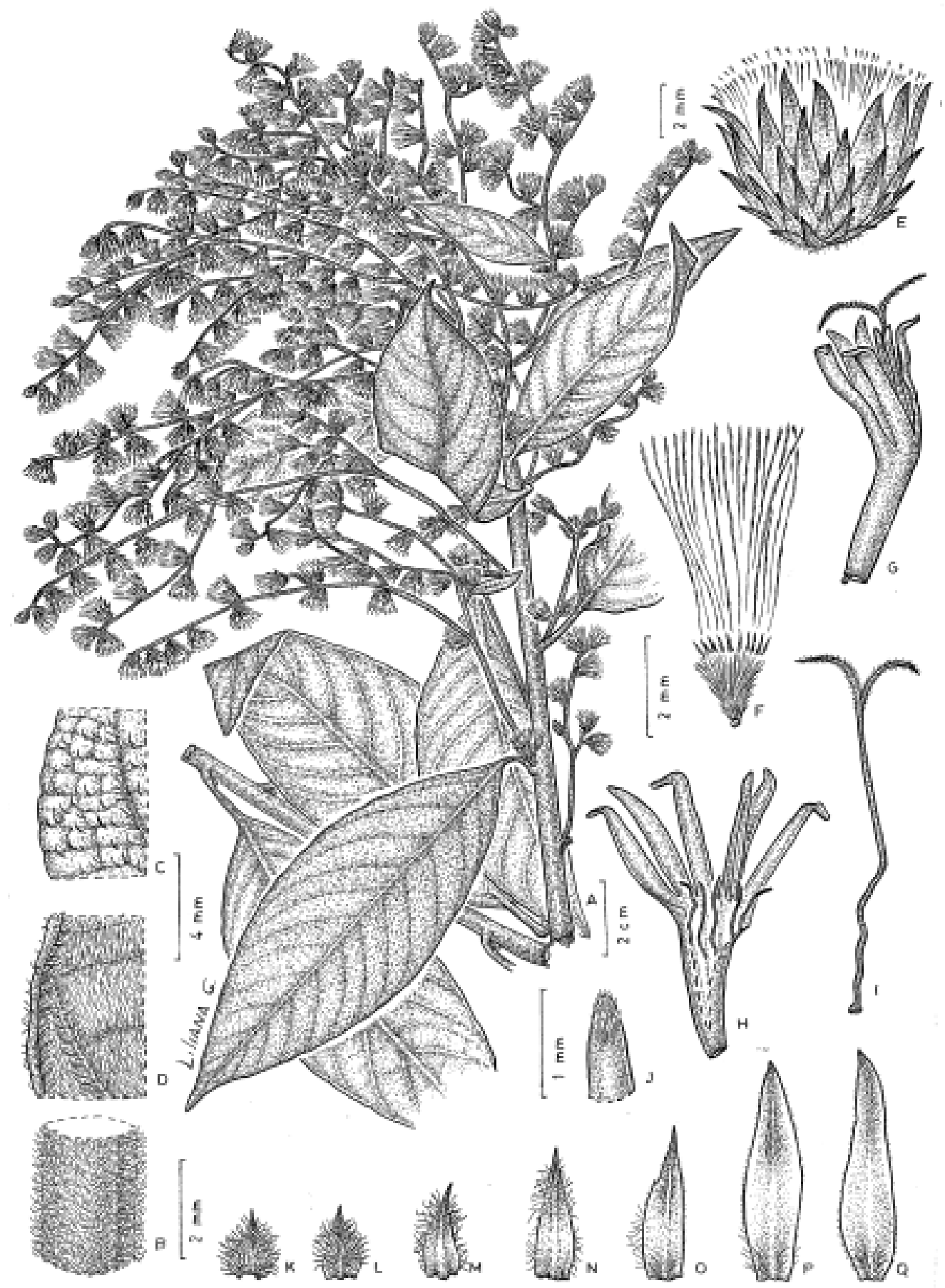

FIGURE 3. Lepidaploa argyrotricha. A. Plant. B. Stem detail. C. Abaxial leaf surface detail. D. Abaxial leaf surface detail. E. Capitula. F. Cypsela and pappus. G. Floret. H. Floret dissected with anther detail. I. Style. J. Corolla lobe detail. K-M. Outer phyllaries. N-Q. Inner phyllaries.

Erect subshrubs $0.9 \mathrm{~m}$ tall; branches velutinous. Leaves distichous, cauline, internodes $1.5-1.6 \mathrm{~cm}$ long, petioles $13.5-$ $14 \mathrm{~mm}$ long; blade 13.55-14.6 × 4.1-4.7 cm, membranaceous-coriaceous, rugose, elliptic to lanceolate, apex acute to caudate, margins entire, base cuneate, adaxial surface strigose, abaxial surface velutinous; venation eucamptodromous. Capitulescence seriate-cymose with capitula sessile, $12,7 \mathrm{~cm}$ long, axis densely velutinous, golden. Involucre narrowly campanulate, 6-8 $\mathrm{mm}$ in diam., phyllaries 5-6-seriate, brown or reddish, membranaceous, villous, outer oval-lanceolate, apex apiculate, intter elliptic-lanceolate, apex apiculate. Florets 18-19, corolla lilac, tube 3.2-4 mm 
long, glabrous, lobes 2-2.5 mm long, lanceolate, apex setose; apical anther appendages obovate, base sagittate; basal stylar node enlarged. Cypsela turbinate to obconic, 1.55-1.7 mm long, setose; carpopodium annular. Pappus white.

Selected specimens examined-BRASIL. Paraná: Bocaiúva do Sul, Estancia Sesmaria, roadside, 27 January 2005, E. Barbosa 1012 (CTES, MBM).

Distribution and habitat - The species is very rare in southern South America. It was found only in one locality in the state of Paraná in Brazil. It was collected in the Atlantic Rainforest (Figure 2).

Phenology - Collected with flowers and fruits between December and March.

Notes - The species may be confused with $L$. chamissonis because of its whitish indumentum on the abaxial leaf surface. However, L. argyrotricha has blade leaves 13.5-14.6 × 4.1-4.7 cm (versus 2.7-9.8 × 1.8-3.9 cm), petiole 13.5-14 mm (versus 5-7 mm) long and corolla lobes without glandular trichomes (versus with glandular trichomes). In addition, $L$. argyrotricha has a very restricted distribution while $L$. chamissonis has a broader distribution in southern South America.

3. Lepidaploa balansae (Hieron.) Robinson (1994: 27). Vernonia balansae Hieronymus (1897: 690). Type:-PARAGUAY. Guarapí, 1 August 1881, B. Balansa 3060 (syntypes G! CORD!, K! [online image!]). Figure 4.

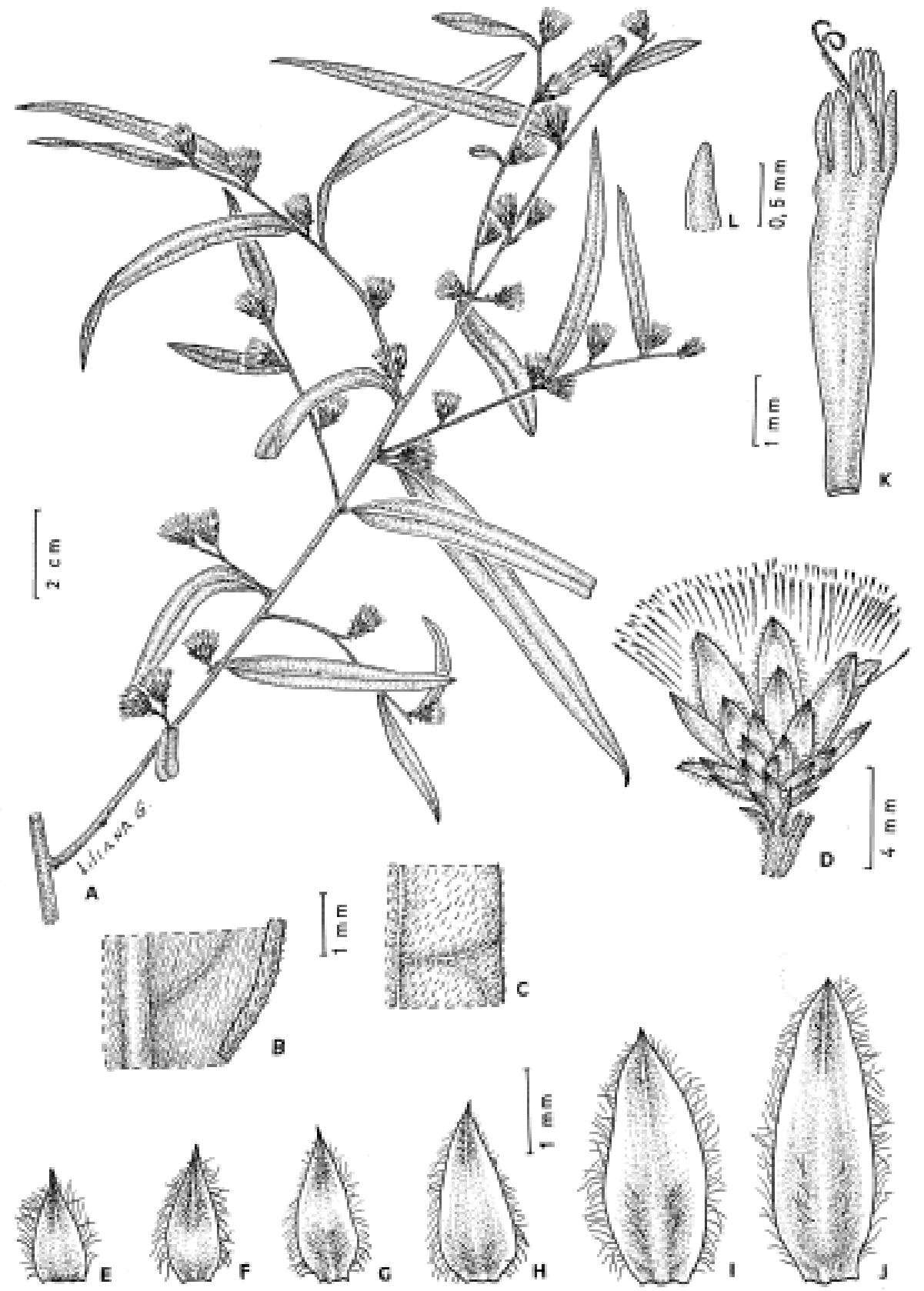

FIGURE 4. Lepidaploa balansae. A. Plant. B-C. Leaf detail. D. Capitula. E-G. Outer phyllaries. H-J. Inner phyllaries. K. Floret. L. 
Clambering shrubs 0.5-3 m tall; branches pubescent. Leaves distichous, cauline, internodes 1.2-2.6 cm long, petioles $0.28-0.35 \mathrm{~mm}$ long, blade $4.4-14.9 \times 0.2-2.9 \mathrm{~cm}$, membranaceous to cartaceous, smooth, lanceolate to linear-lanceolate, apex acute, margins entire, revolute, base attenuate, adaxial surface glabrous, abaxial surface incanous; venations brochidodromous. Capitulescence seriate-cymose with capitula sessile $6.2-8 \mathrm{~cm}$ long, axis glabrous or glabrescent, brown. Involucre turbinate, 6-7 $\mathrm{mm}$ in diam., phyllaries 5-6-seriate, brown to greenish, membranaceous, pubescent, outer ovate, apex apiculate, inner elliptic-lanceolate, apex obtuse to rotund. Florets 10-12, corolla lilac, white, tube 4.5-5 mm long, glabrous, lobes 1.2-2 mm long, lanceolate, apex setose-glandular; apical anther appendages obtuse, base sagittate; basal stylar node narrow. Cypsela turbinate, 1-1.2 mm long, setose; carpopodium anullar. Pappus brown.

Selected specimens examined -ARGENTINA. Corrientes: Departamento Santo Tomé, Arroyo Chimiray, 23 September 1974, M. Krapovickas 26236 (CTES). Misiones: Departamento Guaraní, Predio Guaraní, Rute 15, 8 September 1994, A. Schinini 28740 (CTES). BRASIL. Paraná: Município de Campo Mourão, Parque do Lago, 28 July 2004, M.G. Caxambú 518 (MBM). Santa Catarina: Município de São Miguel d'Oeste, Paraíso, Peperi, 1 September 1964, R.M. Klein 5726 (HBR). Rio Grande do Sul: Departamento Gaurama, estrada secundária em direção a BR 153, 24 August 1996, J.A. Jarenkow 3119 (MBM). PARAGUAY. Alto Paraná: Distrito Alto Vera, Cordillera San Rafael, 14 December 2001, F. González 256 (FCQ). Caazapá: Departamento Mbaracayú, Comunidad Mbyá, 1 July 1989, I. Basualdo 2544 (CTES, FCQ). Canindeyú: Rumbo Norte, 20 August 1996, B. Jiménez 1408 (CTES). Concepción: Estancia San Fernando, Potrero Mamorei, 09 July 1991, I. Basualdo 3500 (FCQ). Guairá: Cordillera Ybytyruzú, Ruta Cantera Jhú, 8 km S de Coronel Oviedo, 16 December 1989, E. Zardini 14967 (FCQ). Itapúa: Estancia Parabel Itapuá, 10 June 1988, S. Kell 1509 (FCQ). Paraguarí: Cerro Palacios, 5 km N de Paraguarí, 26 January 1989, E. Zardini 9801 (FCQ).

Distribution and habitat - The species is widely distributed throughout southern South America. It can be found in Argentina (Misiones and Corrientes), south of Brazil (Paraná, Santa Catarina and Rio Grande do Sul), and Paraguay (Alto Paraná, Caazapá, Canindeyú, Concepción, Guairá, Itapúa and Paraguarí). It can also be found in the following departments of Paraguay: Amambay, Caaguazú, Cordillera and San Pedro (Dematteis \& Cabrera 2009). Lepidaploa balansae grows in the Atlantic Rainflorest, often near waterbodies (Figure 5).

Phenology - Collected with florets and fruits during most part of the year.

Notes - It can be recognized by the clambering habit, incanous abaxial leaf surface, turbinate heads with 10-12 florets, narrow basal stylar node, brown pappus and a wide distribution in southern South America.

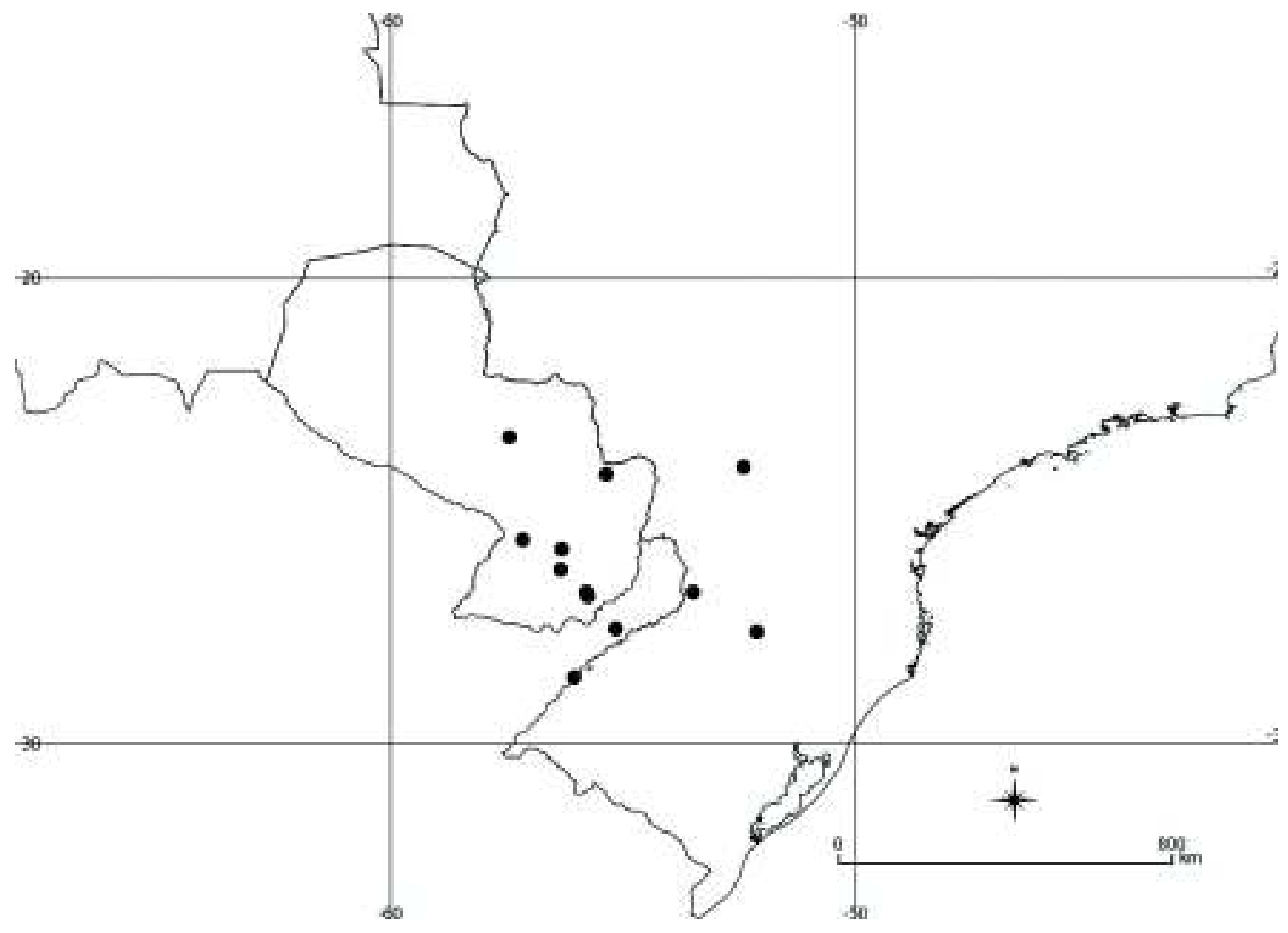

FIGURE 5. Geographical distribution of L. balansae (circle) in Cone Sur. 
4. Lepidaploa chamissonis (Less.) Robinson (1990: 485). Vernonia chamissonis Lessing (1829: 304). Type:-BRAZIL. Without locality, L. A. von Chamisso s.n. (syntype P! [online image!]). Figure 6.

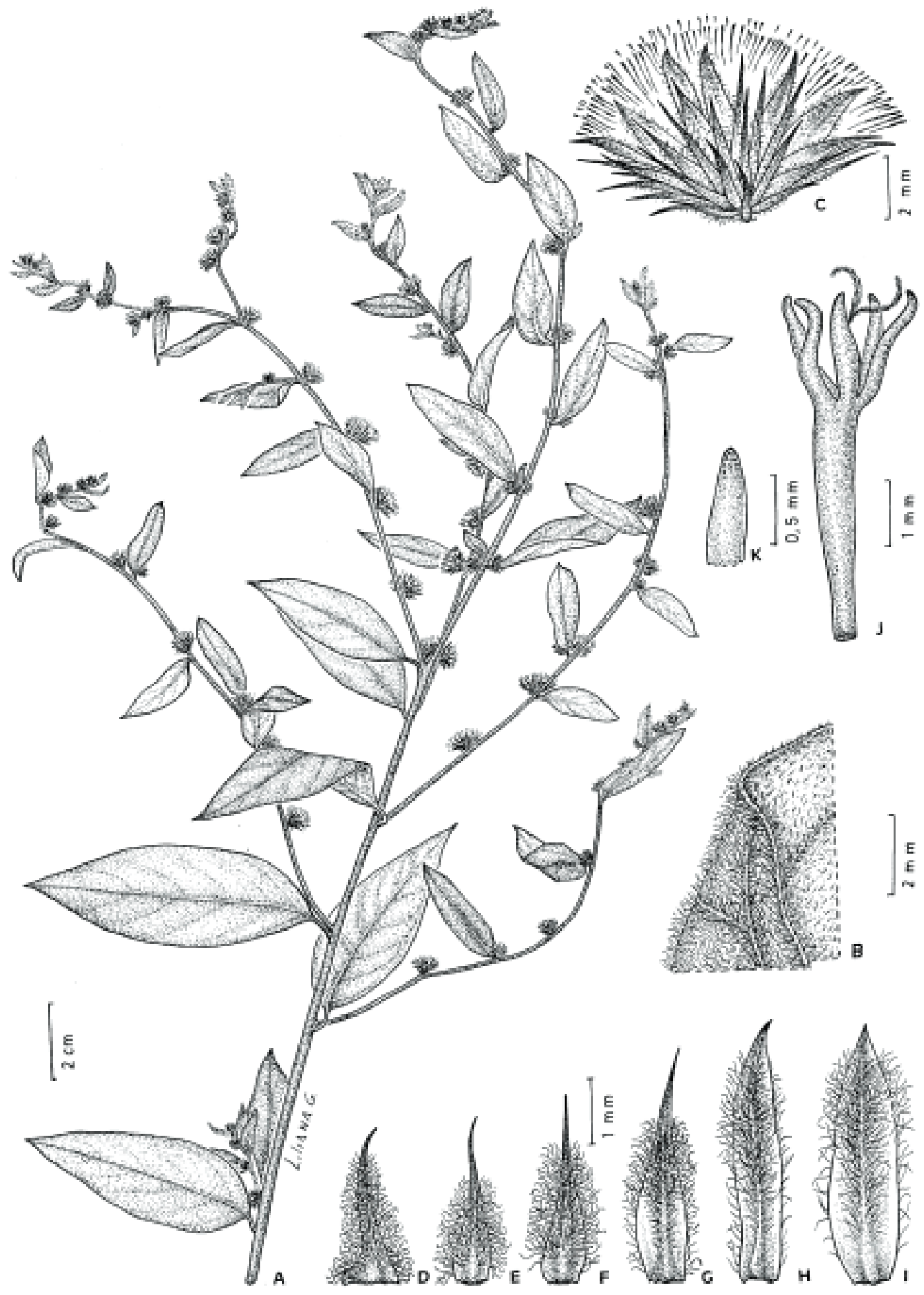

FIGURE 6. Lepidaploa chamissonis. A. Plant. B. Leaf detail. C. Capitula. D-F. Outer phyllaries. G-I. Inner phyllaries. J. Floret. K. Corolla lobe detail. Source: Marques \& Dematteis (2014).

Subshrubs 0.5-1.7 m tall; branches pubescent. Leaves distichous, cauline, internodes $2.4-3.1 \mathrm{~cm}$ long, petioles 5-7 $\mathrm{mm}$ long, blade 2.7-9.8 $\times 1.8-3.9 \mathrm{~cm}$, chartaceous to membranaceous, smooth or rugose, oval, oval-lanceolate, ovatelanceolate, apex acute, margins entire, base attenuate, adaxial surface pubescent, abaxial surface velutinous; venation eucamptodromous. Capitulescence seriate-cymose with capitula sessile, 13-24.5 cm long, axis densely velutinous, golden or brown. Involucre campanulate, 5.4-6.2 mm, phyllaries 4-5-seriate, chestnut, scarious, pubescent, outer oval-lanceolate, apex largely apiculate, inner elliptic-lanceolate, apex acute. Florets 20-24, corolla white, pink, tube 
1.9-2.2 mm long, glabrous, lobes 2.1-2.4 mm long, lanceolate, apex setose-glandular; apical anther appendages acute, base obtuse; basal stylar node enlarged. Cypsela turbinate, 1.2-1.34 mm long, setose; carpopodium anullar. Pappus white.

Selected specimens examined-ARGENTINA. Chaco: Departamento Comandante Fernández, $22 \mathrm{~km}$ SE de Campo Largo, 19 February 1980, A. Schinini 19999 (CTES). Corrientes: Corrientes Capital, Costa del Río Paraná, 08 July 1978, A. Schinini 15251 (CTES). Formosa: Bartolomé de las Casas, 08 May 1969, A. Schinini 16950 (CTES). BRASIL. Paraná: Tomazina, Corredeira, Rio das Cinzas, 24 November 1987, G. Hatschbach 51930 (MBM). Santa Catarina: Florianópolis, Bairro Vargem do Bom Jesus, Rua: Servidão Marcelino Antônio Nunes, 13 March 2010, $A$. Stival-Santos 2022 (FURB). PARAGUAY. Paraguarí: Parque Nacional Ibycui, sin fecha, G. Schmeda 55 (CTES). Presidente Hayes: Ruta Trans-Chaco, río Lindo Monte, 14 March 1979, A. Schinini 16585 (CTES).

Distribution and habitat - In the study region the species is distributed in Argentina, Brazil and Paraguay. In Argentina it is restricted to the provinces of Chaco, Corrientes and Formosa; and in southern Brazil the species is found in Paraná and Santa Catarina, but can also be found in Minas Gerais and São Paulo. In Paraguay, L. chamissonis was collected in the provinces of Paraguarí and Presidente Hayes. The species occurs on fields, in the Atlantic Rainforest and the Cerrado (Figure 7).

Phenology - The species is flowering from October to May.

Notes-This species can be confused with L. salzmannii and L. argyrotrycha, since the three species have a whitish indumentum on the abaxial leaf surface. However, L. argyrotricha is the only species among the three that has a long petiole (13.5-14 mm) and glandular trichomes absent in the corolla lobe. Lepidaploa chamissonis differs from $L$. salzmannii by its ovate, oval-lanceolate, ovate-lanceolate leaves and setose cypselae without idioblasts, while L. salzmannii has lanceolate leaves and setose-glandular cypselae with idioblasts. In addition, L. chamissonis is more widely distributed in southern South America, while L. salzmannii is restricted to the states of Paraná and Santa Catarina in Brazil.

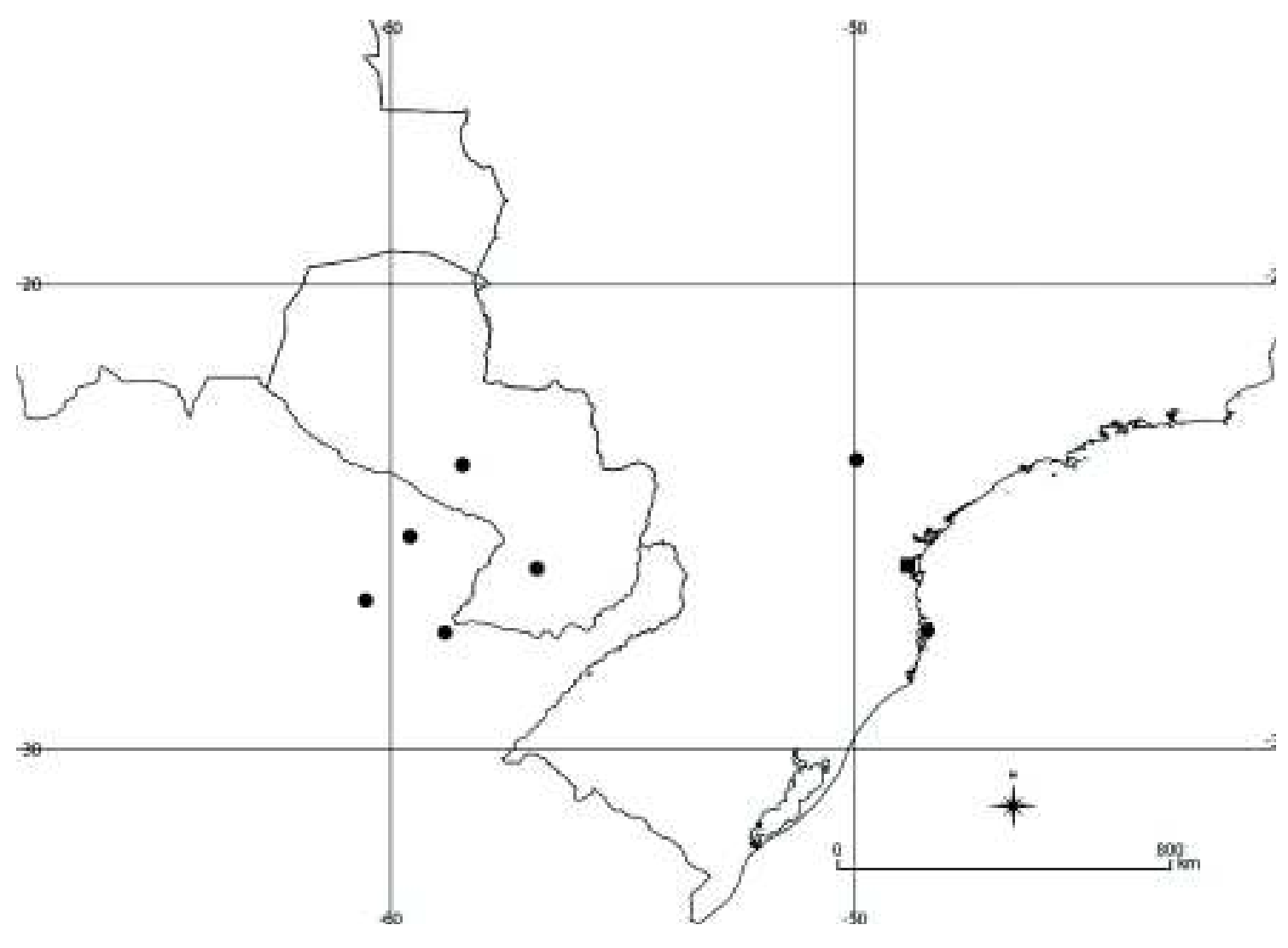

FIGURE 7. Geographical distribution of L. chamissonis (circle) and L. decumbens (square) in Cone Sur. 
5. Lepidaploa decumbens (Gardner) Robinson (1990: 486). Vernonia decumbens Gardner (1845: 115).

Type:-BRAZIL. Without locality, G. Gardner 517 (syntypes B! E! F! G! K! NY! P! [online image!]). Figure 8.

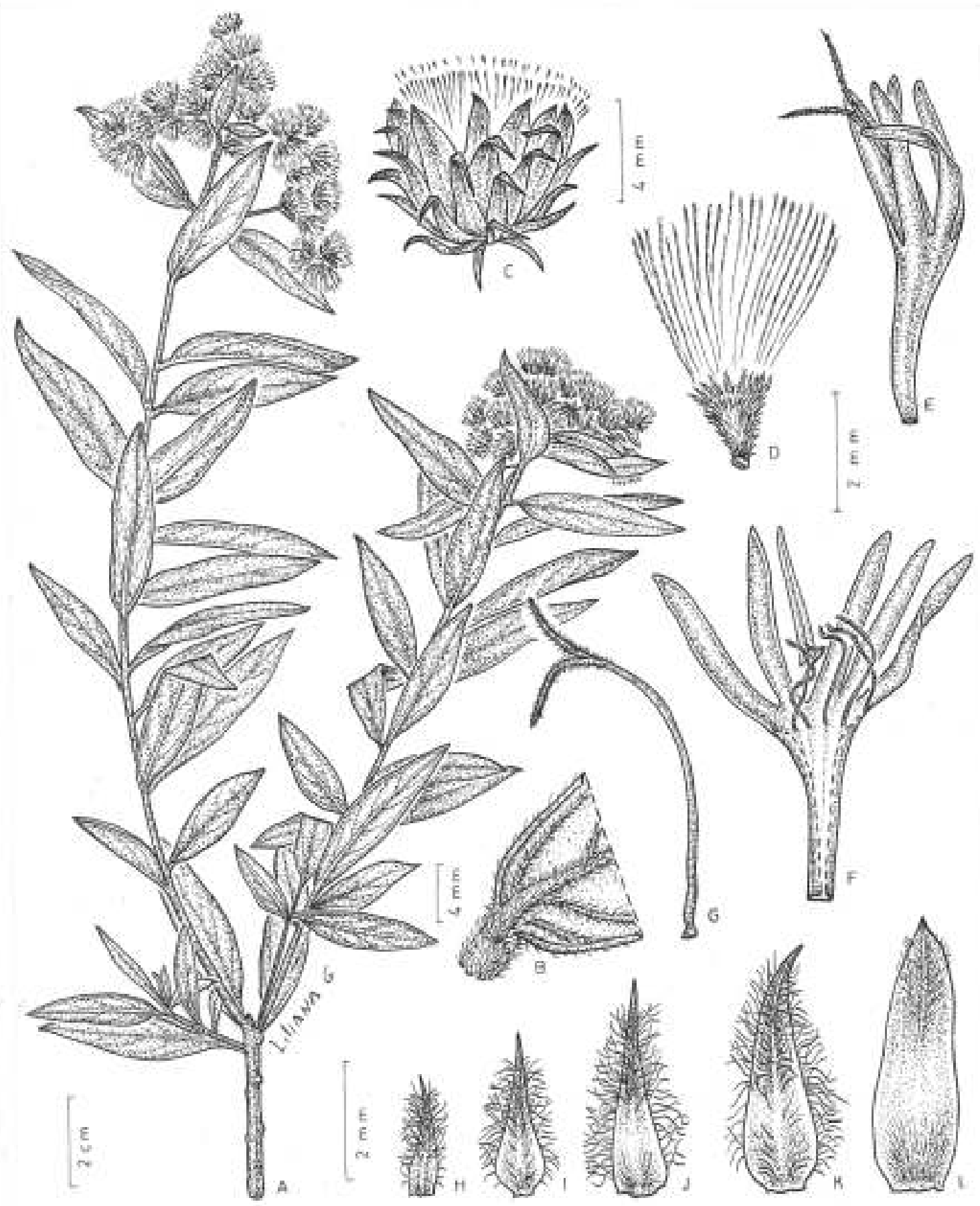

FIGURE 8. Lepidaploa decumbens. A. Plant. B. Abaxial leaf surface detail. C. Capitula. D. Cypsela and pappus. E. Floret. F. Floret dissected with anther detail. G. Style. H-I. Outer phyllaries. K-L. Inner phyllaries.

Herbs $0.2-0.6 \mathrm{~m}$ tall; branches glabrescent. Leaves distichous, cauline, internodes ca. $1 \mathrm{~cm}$ long; sessile, blade 7-10 $\times 0.8-1.34 \mathrm{~cm}$, membranaceous, weakly rugose, lanceolate, apex largely acute, margins entire, revolute, base cuneate, both surfaces strigose; venation camptodromous. Capitulescence short seriate-cymose with capitula sessile, 1.6-3.6 $\mathrm{cm}$ long, axis glabrescent, brown. Involucre campanulate, 7-8 $\mathrm{mm}$ in diam., phyllaries 5-6-seriate, chestnut, scarious, densely tomentose, outer oval-lanceolate, apex apiculate-recurved, inner lanceolate, apex apiculate-recurved. Florets 15-20, corolla violet, tube 2.5-3 mm long, glabrous, lobes 3.5-4 mm long, lanceolate, apex glandular; apical anther appendages acute, base sagittate; basal stylar node enlarged. Cypsela turbinate to obconic, 1.5-2 mm long, velutinous; carpopodium anullar. Pappus white. 
Selected specimens examined-BRASIL. Santa Catarina: Garuva, Morro Crista, 19 January 1961, R. Reitz \& R. M. Klein 10647 (HBR). idem, 23 March 1961, R. Reitz \& R. M. Klein, 10895 (HBR). Minas Gerais: Parque Nacional do Caparaó, 14.VI.1991, G. Hatschbach \& D. Guimarães 55471 (CTES).

Distribution and habitat - In southern South America Lepidaploa decumbens is restricted to the states of Paraná (Dematteis \& Almeida 2015) and Santa Catarina (Cabrera \& Klein 1980) in Brazil. In Santa Catarina this species was found in the Cerrado (Figure 7).

Phenology - The species blooms between January and March.

Notes - Lepidaploa decumbens can be recognized by the following combination of characters: apiculate-recurved phyllaries, lanceolate leaves with revolute margins, camptodromous venation and short inflorescence $(1.6-3.6 \mathrm{~cm}$ long).

6. Lepidaploa eriolepis (Gardner) Robinson (1990: 487). Vernonia eriolepis Gardner (1846: 224). Type:-BRAZIL. Without locality, G. Gardner 1718 (syntypes BR! F! GH! K!, NY! S! [online image!]). Figure 9.

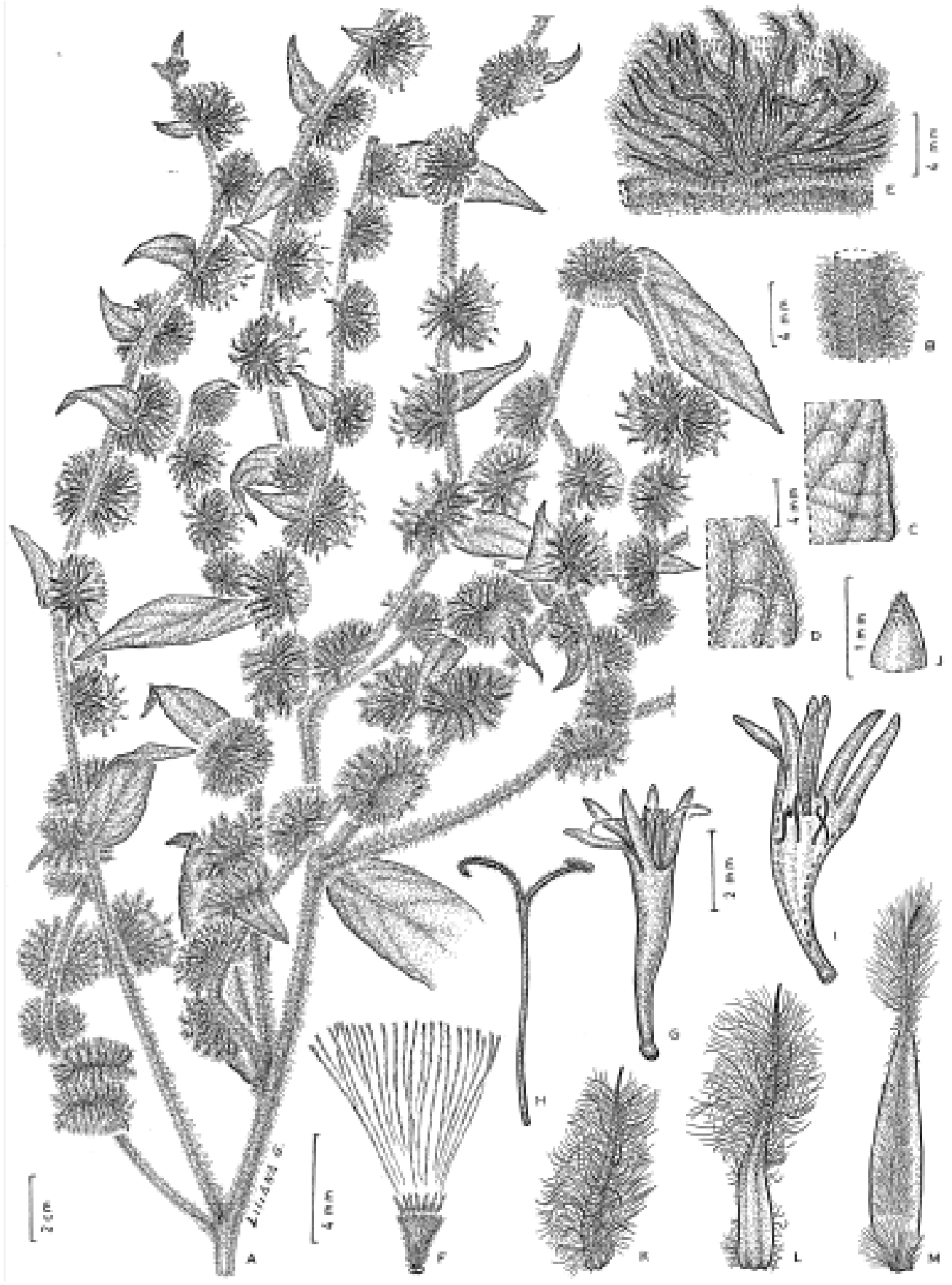

FIGURE 9. Lepidaploa eriolepis. A. Plant. B. Stem detail. C. Abaxial leaf surface detail. D. Abaxial leaf surface detail. E. Capitula. F. Cypsela and pappus. G. Floret. H. Style. I. Floret dissected with anther detail. J. Corolla lobe detail. K. Outer phyllaries. L-M. Inner phyllaries. 
Herbs, subshrubs or erect shrubs 0.9-2 m tall; branches densely strigose-tomentose, slightly ribbed. Leaves distichous, cauline, internodes 4.2-4.9 cm long, petioles 7.7-9 mm long, blade 12.2-15.4 ×4.1-6 cm, membranaceous, rugose, ovate-lanceolate, apex caudate, margins denticulate, base attenuate, both surfaces densely strigose-tomentose; venation eucamptodromous-reticulodromous. Capitulescence seriate-cymose with capitula sessile, $8.3-17.4 \mathrm{~cm}$ long, axis densely strigose-tomentose, ferruginous. Involucre widely campanulate, $8.7-10.5 \mathrm{~mm}$ in diam., phyllaries 5-6seriate, chestnut, membranaceous, densely strigose-tomentose, outer oval-lanceolate, apex apiculate, inner ellipticlanceolate, apex acute. Florets 35-40, corolla white, tube 4.5-5 mm long, glabrous, lobes 2-2.5 mm long, lanceolate, apex setose; apical anther appendages acute, base sagittate; basal stylar node enlarged. Cypsela turbinate to obconic, 1.5-2 mm long, velutinous; carpopodium anullar. Pappus chestnut.

Specimens examined-BRASIL. Paraná: Antonina, Usina Hidrelétrica Parigot de Souza, Cota 800, 5 October 2006, J.M. Silva 5007 (CTES, MBM). Santa Catarina: Santo Amaro da Imperatriz, Cova da Onça, 12 August 2009, $A$. Stival-Santos 785 (MBM).

Distribution and habitat - Lepidaploa eriolepis is scarcely distributed in the study region, occurring exclusively in Paraná and Santa Catarina, Brazilia. In these states this species grows in the Atlantic Rainforest or the Cerrado (Figure 10).

Phenology - Collected with flowers from June to December.

Notes-The species can be recognized by its heads with 35-40 florets, restricted distribution, presence of a strigose-tomentose and ferruginous indumentum covering the whole plant (branches, leaves, phyllaries), and pappus chestnut.

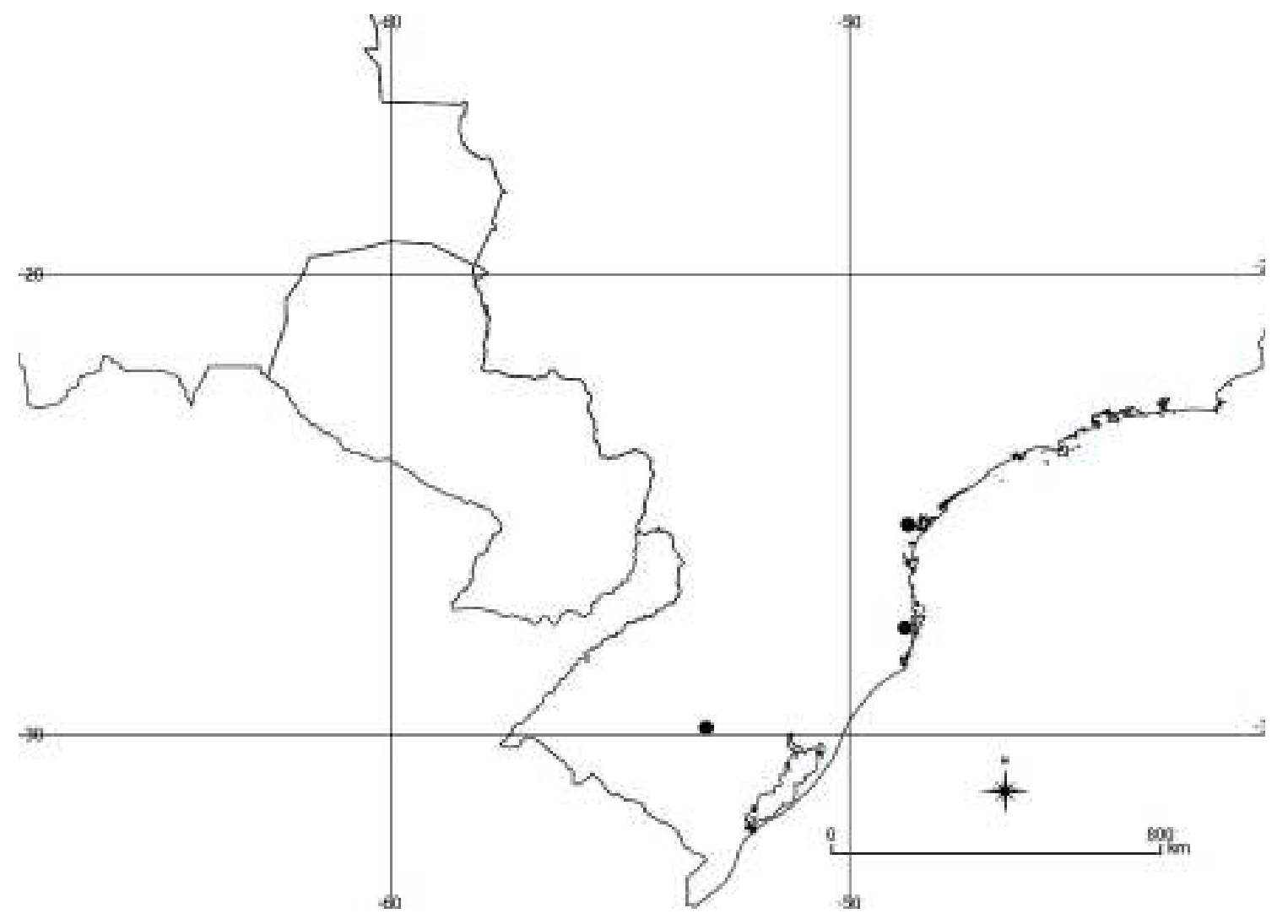

FIGURE 10. Geographical distribution of L. eriolepis (circle) in Cone Sur.

7. Lepidaploa novarae (Cabrera) Vega \& Dematteis (2012: 269). Vernonia novarae Cabrera (1997: 255).

Type:-ARGENTINA. Salta province, Santa Victoria department, Parque Nacional Baritú, between Quebrada La Gateada and Quebrada Seca, 20 Septiember 1990, L. J. Novara 9993 (holotype MCNS! [photo!]; isotypes M!, SI! [photo!]). Figure 11.

Clambering shrubs 1-2 $\mathrm{m}$ tall; branches pubescent. Leaves distichous, cauline, internodes $3.3-5.5 \mathrm{~cm}$ long, petioles 5$10 \mathrm{~mm}$ long, blade $7-15 \times 1.5-3.5 \mathrm{~cm}$, membranaceous, rugose, elliptic-lanceolate or lanceolate, apex acute, margins entire, rarely sinuate, base attenuate, adaxial surfaces glabrous, abaxial surface pubescent or glabrous; venation camptodromous-eucamptodromous. Capitulescence seriate-cymose with capitula sessile, 4.7-11.3 cm long, axis densely tomentose-velutinous, brown. Involucre narrowly campanulate, 6-7 $\mathrm{mm}$ in diam., phyllaries 5-6-seriate, 
brown, scarious, glabrous or pubescent, outer oval-lanceolate, apex apiculate, inner elliptic-lanceolate, apex acute. Florets 20-25, corolla white, tube 3-6 mm long, glabrescent, lobes 2.5-3.5 mm long, lanceolate, apex setose-glandular; apical anther appendages acute, base obtuse; basal stylar node enlarged. Cypsela turbinate to obconic, 2-2.3 mm long, sericeous, idioblasts present; carpopodium anullar. Pappus white or grayish.

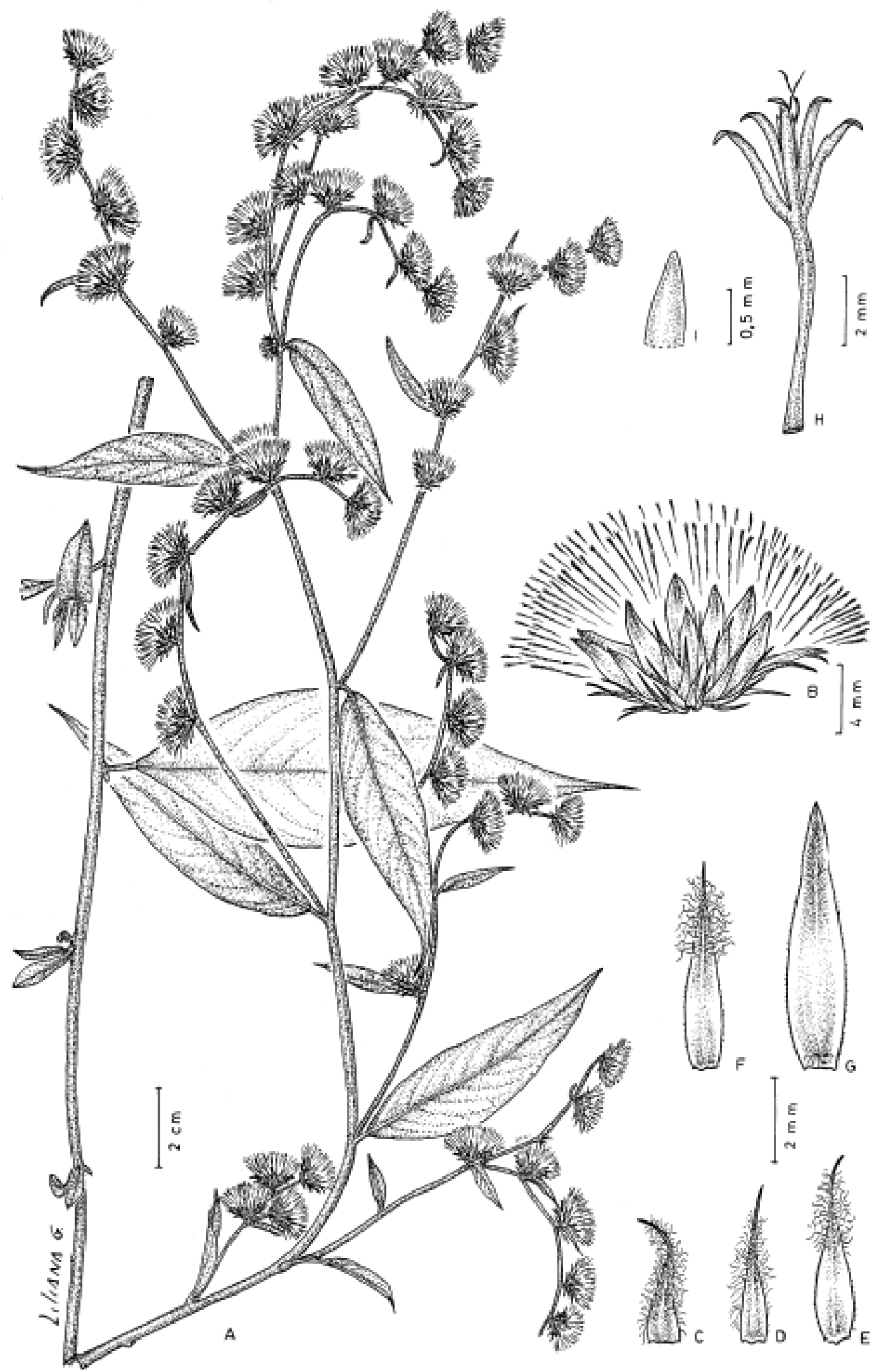

FIGURE 11. Lepidaploa novarae. A. Plant. B. Capitula. C-D. Outer phyllaries. E-G. Inner phyllaries. H. Floret. I. Corolla lobe detail. 
Selected specimens examined -ARGENTINA. Salta: Departamento de Santa Victoria, Parque Santa Victoria, Camino a río San José desde desvío de camino de los Toldos a Lipeo, 28 September 1998, O. Ahumada 8177 (CTES). Salta Capital, Parque San Martín, entrando por pista de aterrizaje de Los Toldos, bordeando la costa del río Toldo, 03 October 1998, O. Ahumada 8365 (CTES).

Distribution and habitat - Lepidaploa novarae was reported only from the province of Salta in Argentina and, therefore, is endemic to this region. In Salta, the species was found in the departments of Salta and Santa Victoria. According to Marques \& Dematteis (2014), this species can also be found in the department of Óran, Salta. The species grows in the "yungas salteñas" (North-Central Humid Andes) between 600-1800 m a.s.l. (Figure 12).

Phenology - Collected with flowers in August and September.

Notes - Lepidaploa novarae is similar to L. tarijensis, which also occurs in Salta (Argentina), but the first species grows only in Salta while L. tarijensis occurs in Salta and Bolivia. Both species are clambering shrubs and have glabrous or glabrecent leaves. However, L. novarae is distinct from the similar species because of its involucre 6-7 (versus 8-10) $\mathrm{mm}$ long, presence (versus absence) of glandular trichomes on the corolla lobes, and cypselae with idioblasts (versus without idioblasts).

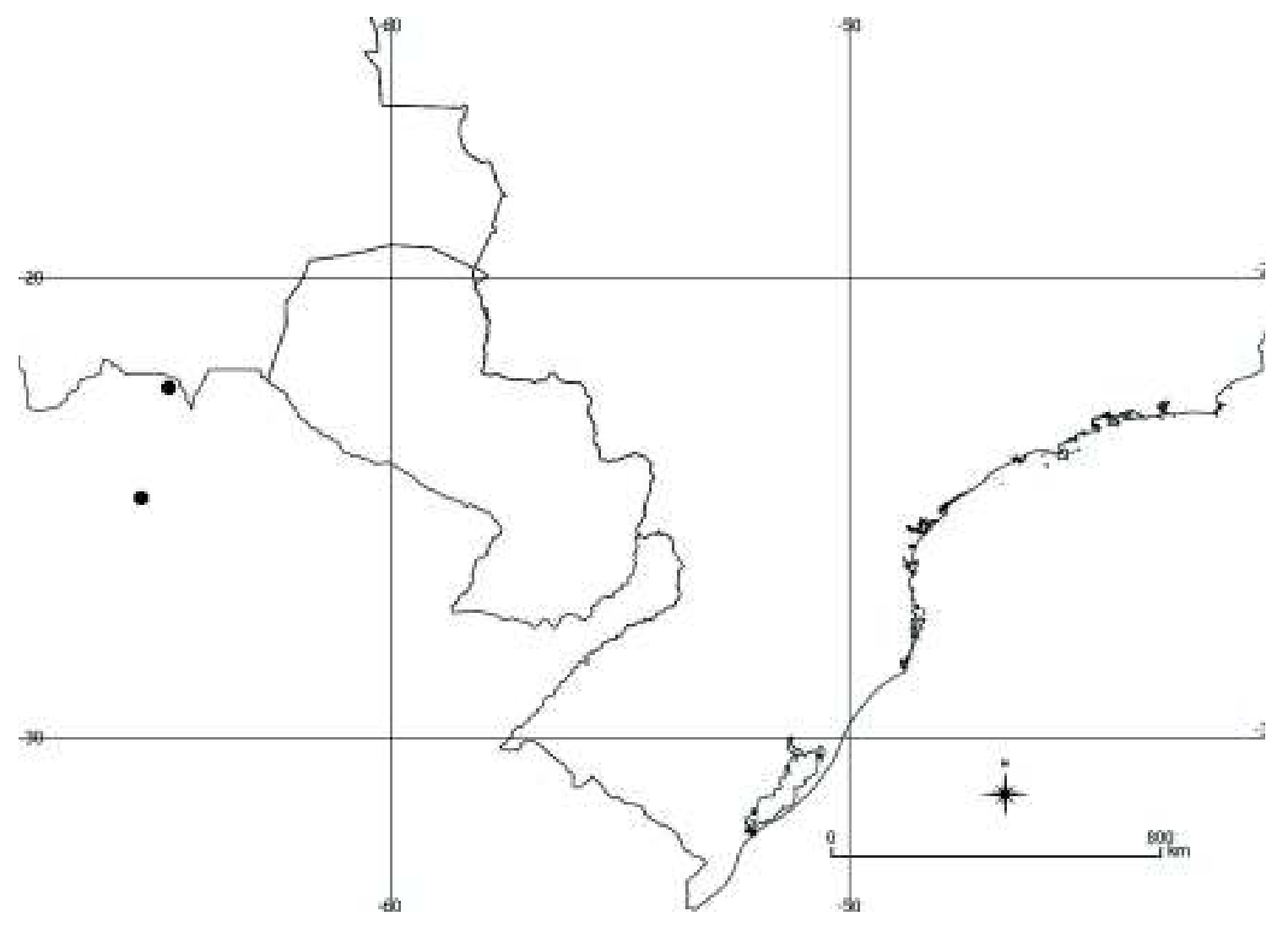

FIGURE 12. Geographical distribution of L. novarae (circle) in Cone Sur.

\section{Lepidaploa pseudomuricata Robinson (1995: 395).}

Type:-BRAZIL. Santa Catarina state, Serra da Boa Vista, São José, 700 m, 12 December 1990, R. Reitz \& R. M. Klein 10614 (holotype US! [photo!]; isotypes HBR! LP). Figure 13.

Erect subshrubs or shrubs $0.8-2 \mathrm{~m}$ tall; branches strigose, prominently ribbed. Leaves spirally alternate, cauline, internodes 2-5 cm long, petioles $0.4-1.3 \mathrm{~mm}$ long, blade $9.5-10.1 \times 1.5-3.4 \mathrm{~cm}$, membranaceous to chartaceous, rugose, lanceolate or oblong-lanceolate, apex acute to caudate, margins denticulate, base cuneate to attenuate, both strigose; venation eucamptodromous-reticulodromous. Capitulescence seriate-cymose with capitula sessile, paniculiform, 13.9-15.5 cm long, axis puberulent to strigose, whitish. Involucre campanulate, 6-7.2 $\mathrm{mm}$ in diam., phyllaries 3-4-seriate, chestnut, membranaceous, strigose, outer oval-lanceolate, apex apiculate, inner lanceolate, apex apiculate. Florets 19-23, corolla lilac or violet, tube 2.9-5.5 mm long, glabrous, lobes 2.6-3.9 mm long, lanceolate, apex glandular; apical anther appendages acute, glandular, lanceolate, base sagittate; basal stylar node narrow. Cypsela turbinate to obconic, 2.2-2.8 mm long, setose; carpopodium anullar. Pappus white. 


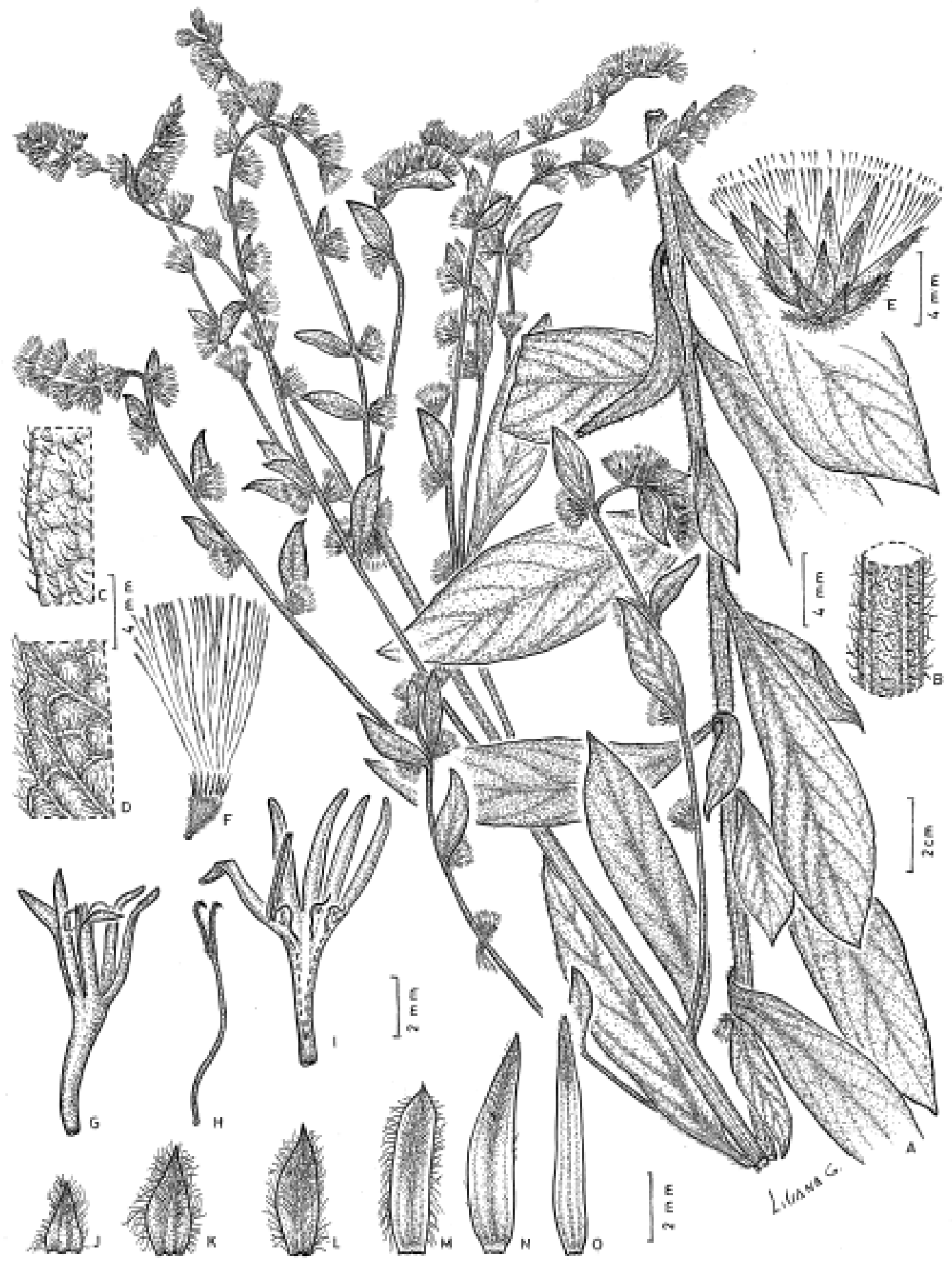

FIGURE 13. Lepidaploa pseudomuricata. A. Plant. B. Stem detail. C. Abaxial leaf surface detail. D. Abaxial leaf surface detail. E. Capitula. F. Cypsela and pappus. G. Floret. H. Style. I. Floret dissected with anther detail. J-L. Outer phyllaries. M-O. Inner phyllaries.

Selected specimens examined-ARGENTINA. Misiones: San Pedro, Camino de tierra que une ruta provincial 17 con ruta nacional 14 a la altura de Piñalito Sur, 13 January 2007, H.A. Keller 3921 (CTES). BRASIL. Paraná: Antonina, Bairro Alto, 10 February 2006, G. Hatschbach 79554 (CTES). Santa Catarina: Bom Jardim da Serra, Fazenda Papagaios, 26 February 2011, M. Verdi 5909 (FURB). Rio Grande do Sul: Bom Jesus, Santo Inácio, 11 March 2005, G. Hatschbach 79077 (CTES).

Distribution and habitat - The species is restricted to the south of Brazil and is known in Argentina through a unique collection from the province of Misiones. Lepidaploa pseudomuricata inhabits fields and wetland regions but is commonly found on margins or under canopy of the Atlantic Rainforest (Figure 14). 
Phenology — The species blooms between April and December.

Notes-The species can be easily differentiated from the other species that occur in southern South America by glandular trichomes on its anthers, prominently ribbed branches, erect subshrubby or shrubby habit and narrow basal stylar node.

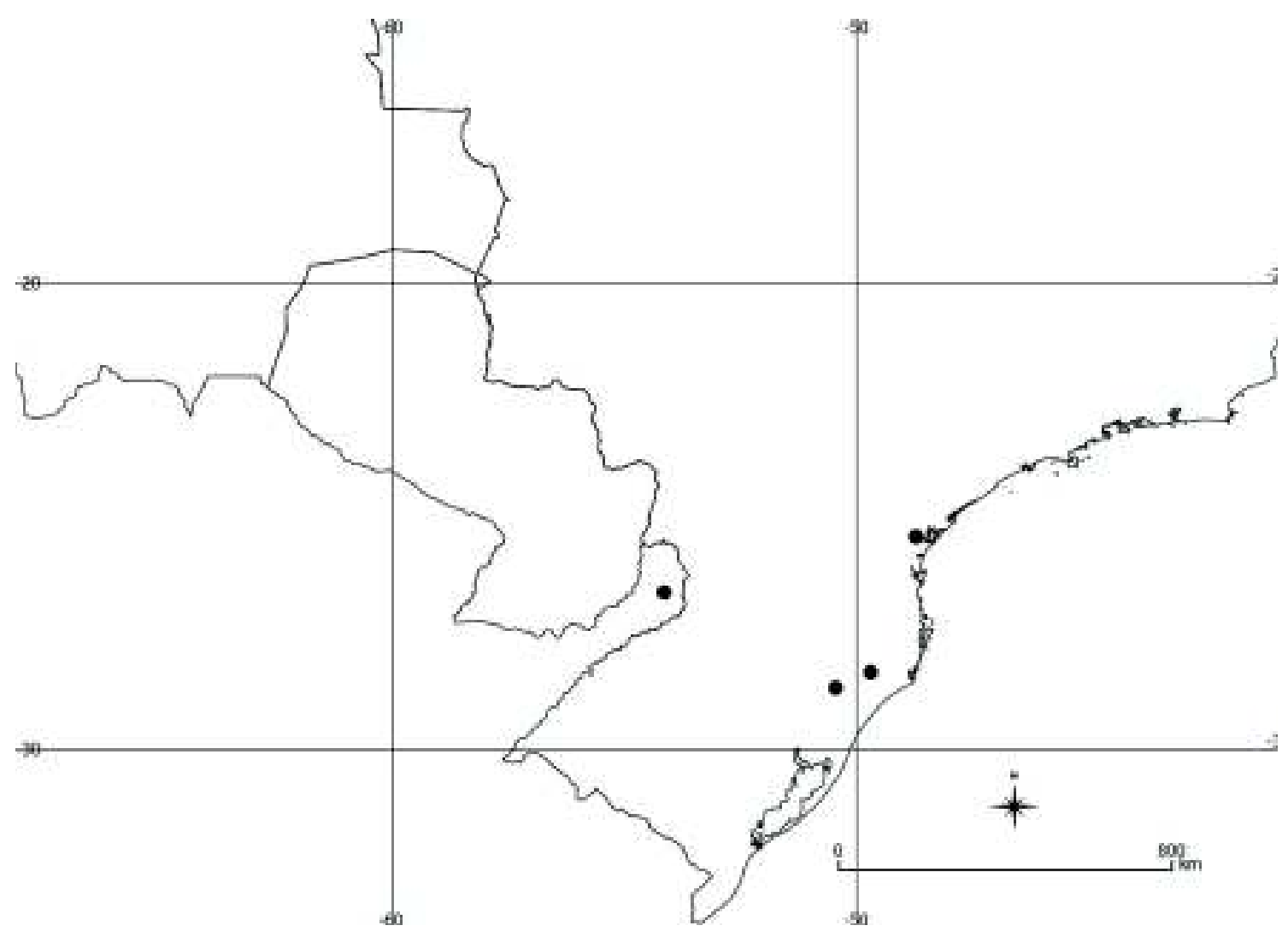

FIGURE 14. Geographical distribution of L. pseudomuricata (circle) in Cone Sur.

9. Lepidaploa psilostachya (DC.) Robinson (1990: 491). Vernonia psilostachya Candolle (1836: 43).

Type:-BRAZIL. São Paulo state, without locality, 1835, P. W. Lund 878 (holotype G-DC! [online image!]). Figure 15.

Subshrubs 0.3-0.45 m tall; branches tomentose-glandular. Leaves distichous, basal and cauline, internodes $2.6-4.5 \mathrm{~cm}$ long, sessile, blade 1.4-3.87 × 0.4-1.2 cm, membranaceous, smooth, basal obovate-lanceolate, cauline lanceolate, apex acute, margins denticulate to serrulate, revolute, base attenuate, adaxial surface strigose, abaxial surface tomentose; venation camptodromous. Capitulescence seriate-cymose with capitula sessile, $\mathrm{ca} .9 \mathrm{~cm}$ long, axis tomentose-glandular, golden. Involucre campanulate, $8-10 \mathrm{~mm}$ in diam., phyllaries 5-6-seriate, brown to reddish, membranaceous, villous to tomentose, outer oval-lanceolate, apex largely apiculate, inner elliptic-lanceolate, apex acute to acute-apiculate. Florets 21-23, corolla lilac to violet, tube 3.2-4 mm long, glabrous, lobes 2-2,5 mm long, lanceolate, apex setose; apical anther appendages obtuse, base obtuse; basal stylar node enlarged. Cypsela turbinate to obconic, 1.55-1.7 mm long, setose, idioblasts present; carpopodium anullar. Pappus white.

Selected specimens examined-ARGENTINA. Misiones: San Ignacio, Casa de H. Quiroga, 16 February 2009, M. Dematteis 3047 (CTES). BRASIL. Paraná: Tibagi, Guartelá, 14 December 2009, L.P. Deble 12020 (CTES).

Distribution and habitat - The species is scarcely distributed in the study region, occurring only in Paraná (Brazil) and Misiones (Argentina). According to Dematteis \& Cabrera (2009), L. psylostachya also occurs in Paraguay in the departments of Alto Paraná and Cordillera. In southern South America it grows on stony fields of the Atlantic Rainforest (Figure 16).

Phenology - Collected with flowers in November, February, and July.

Notes - Lepidaploa psilostachya is similar to L. amambaia. However, L. psilostachya is distinguished from the latter species by having both basal and cauline leaves and acute leaf apex. See comments under L. amambaia. 


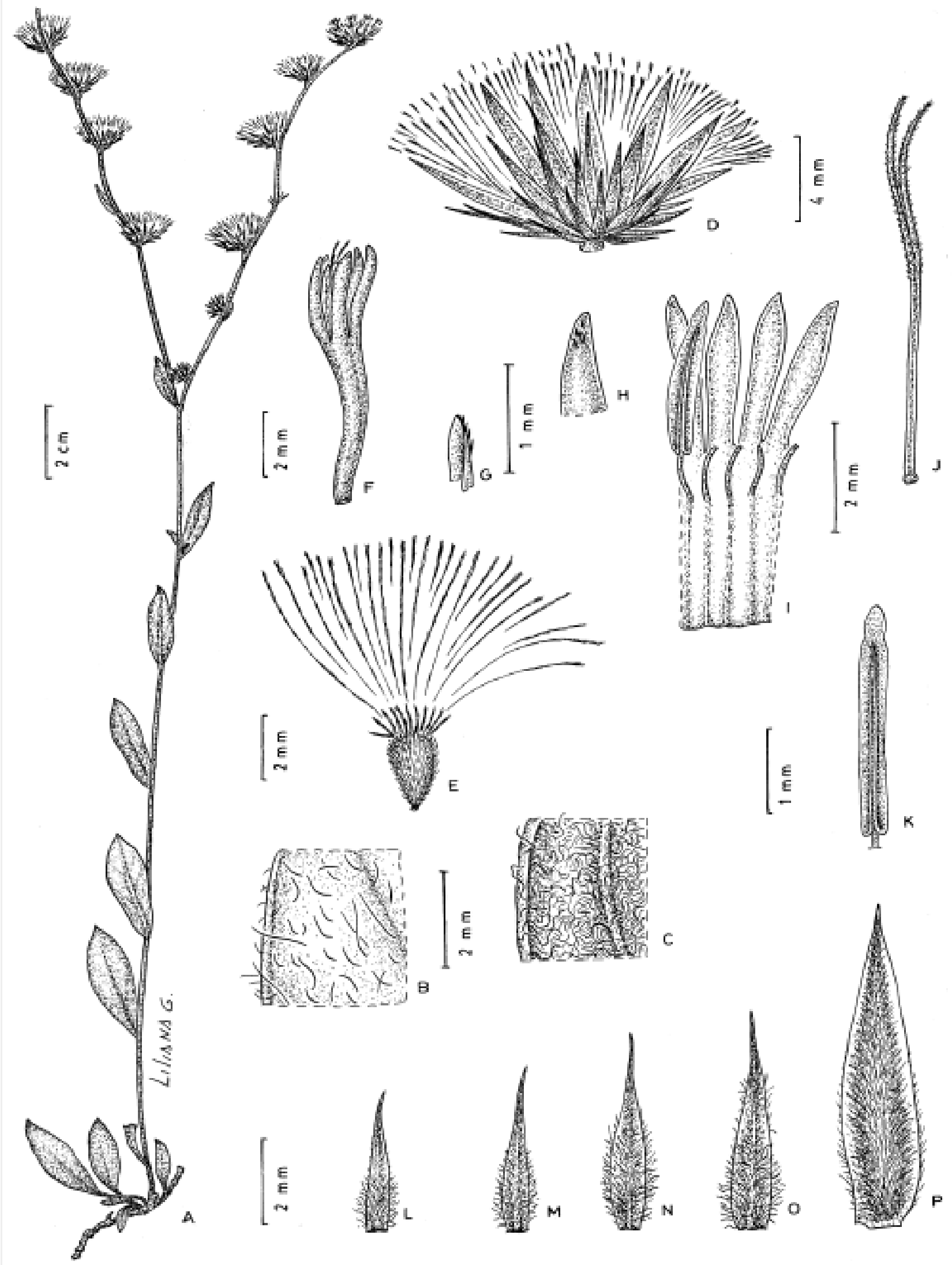

FIGURE 15. Lepidaploa psilostachya. A. Plant. B. Abaxial leaf surface detail. C. Abaxial leaf surface detail. D. Capitula. E. Cypsela. F. Floret. G-H. Corolla lobe detail. I. Floret dissected. J. Style. K. Anther. L-M. Outer phyllaries. N-P. Inner phyllaries. Source: Marques \& Dematteis (2014). 


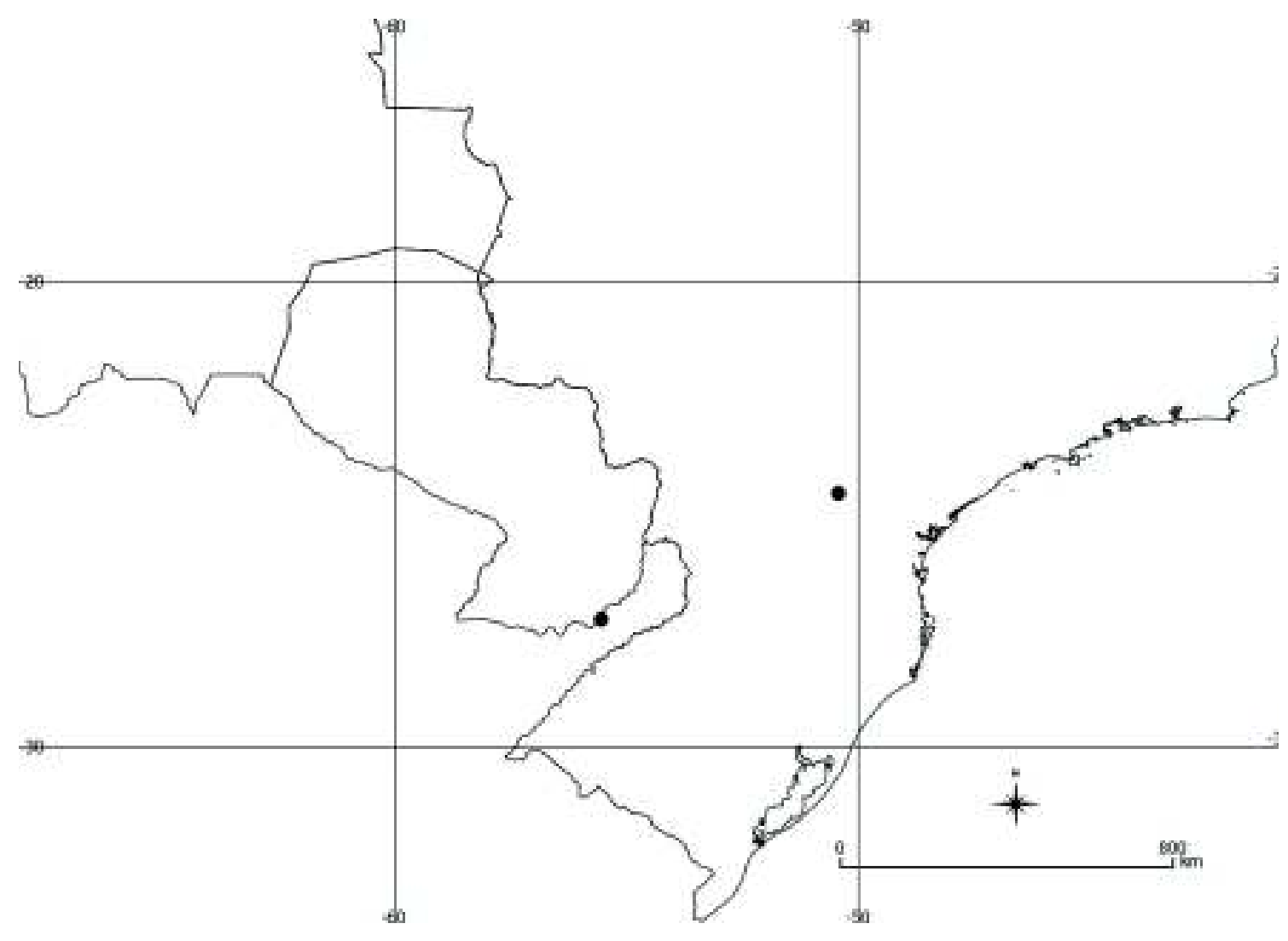

FIGURE 16. Geographical distribution of L. psilostachya (circle) in Cone Sur.

10. Lepidaploa remotiflora (Rich.) Robinson (1990: 491). Vernonia remotiflora Richard (1792: 112).

Type:-FRENCH GUIANA. Without locality, 1792, J. B. Leblond 336 (lectotype G! [photo!], designated by Pruski (1998: 480); isolectotypes C! P! US!). Figure 17.

Herbs or subshrubs $0.3-0.6(-1.20) \mathrm{m}$ tall; branches pubescent. Leaves distichous, cauline, internode 2.2-3.6 cm long, sessile, blade 13.5-14.6 $\times 4.1-4.7 \mathrm{~cm}$, membranaceous, smooth, oval or oval-lanceolate, apex acute, margins serrulate or denticulate, base attenuate, both surfaces strigose; venation eucamptodromous-reticulodromous. Capitulescensce seriate-cymose with capitula sessile, paniculiform, $9.7-42 \mathrm{~cm}$ long, axis densely velutinous, golden. Involucre campanulate, 6-8 mm in diam., phyllaries 5-6-seriate, greenish with blackened apex, scarious, pubescent, outer linearlanceolate, apex apiculate, inner lanceolate, apex acute. Florets 21-23, corola violet, tube 3.5-5 mm long, glabrous, lobes 2.5-3 mm long, lanceolate, apex glandular; apical anther appendages acute to obtuse, base obtuse or sagittate; basal stylar node enlarged. Cypsela turbinate, 1.55-1.7 mm long, strigose, idioblasts present; carpopodium anullar. Pappus white.

Selected specimens examined -ARGENTINA. Corrientes: Ituizangó, Centro Forestal, Villa Olivari, 05 April 1995, S.G. Tressens 5243 (CTES). Formosa: Pilagá, Costa Río Paraguay, 16 March 1979, B. Piccinini 3607 (CTES). Misiones: Eldorado, Ruta Provincial 17, Aldea Guaraní, Pozo Azul, 04 April 2002, H.A. Keller 1778 (CTES). BRASIL. Paraná: Campo Mourão, 02 February 1962, G. Hatschbach 8845 (MBM). Rio Grande do Sul: Bom Jesus, Santo Inácio, 11 March 2005, G. Hatschbach 79080 (MBM). PARAGUAY. Amambay: Amambay, Colina Estrella, $45 \mathrm{~km}$ NW de P.J. Caballero, 08 December 1997, A. Schinini 30545 (CTES). Caazapá: Santa Ursula, 55 km de Yuty, 23 March 1993, A. Schinini 27871 (CTES). Canindeyú: Reserva Natural del Bosque Mbaracayú, 11 km del Puerto "Yeyuí-mi”, 12 February 1997, A. Schinini 33245 (CTES). Central: Central, Areguá, Isla Valle, 10 June 1987, N. Soria 1513 (FCQ). Cordillera: Tobatí, Ybitú Silla, 03 March 1991, E. Zardini 26960 (FCQ). Guairá: Cordillera de Ybytyruzú, Ruta de Cantera Jhú, 27 September 1989, E. Zardini 14889 (FCQ). Itapúa: Capitán Miranda, 4,2 km N del Hotel Tirol detrás del barrio Conavi, 07 October 1993, A. Krapovickas 44450 (CTES). Ñeembucú: Paraguay, Ñeembucú, Estancia Redondo, 29 October 2004, M. Peña-Chocarro 2210 (FCQ). Paraguarí: Paraguarí, costa del Cerro Palacios, 12 January1988, M. Ortíz 423 (FCQ). San Pedro: Río Tapiracuay, 10 km de San Estanislao, 17 February 1968, A. Krapovickas 13886 (CTES). 


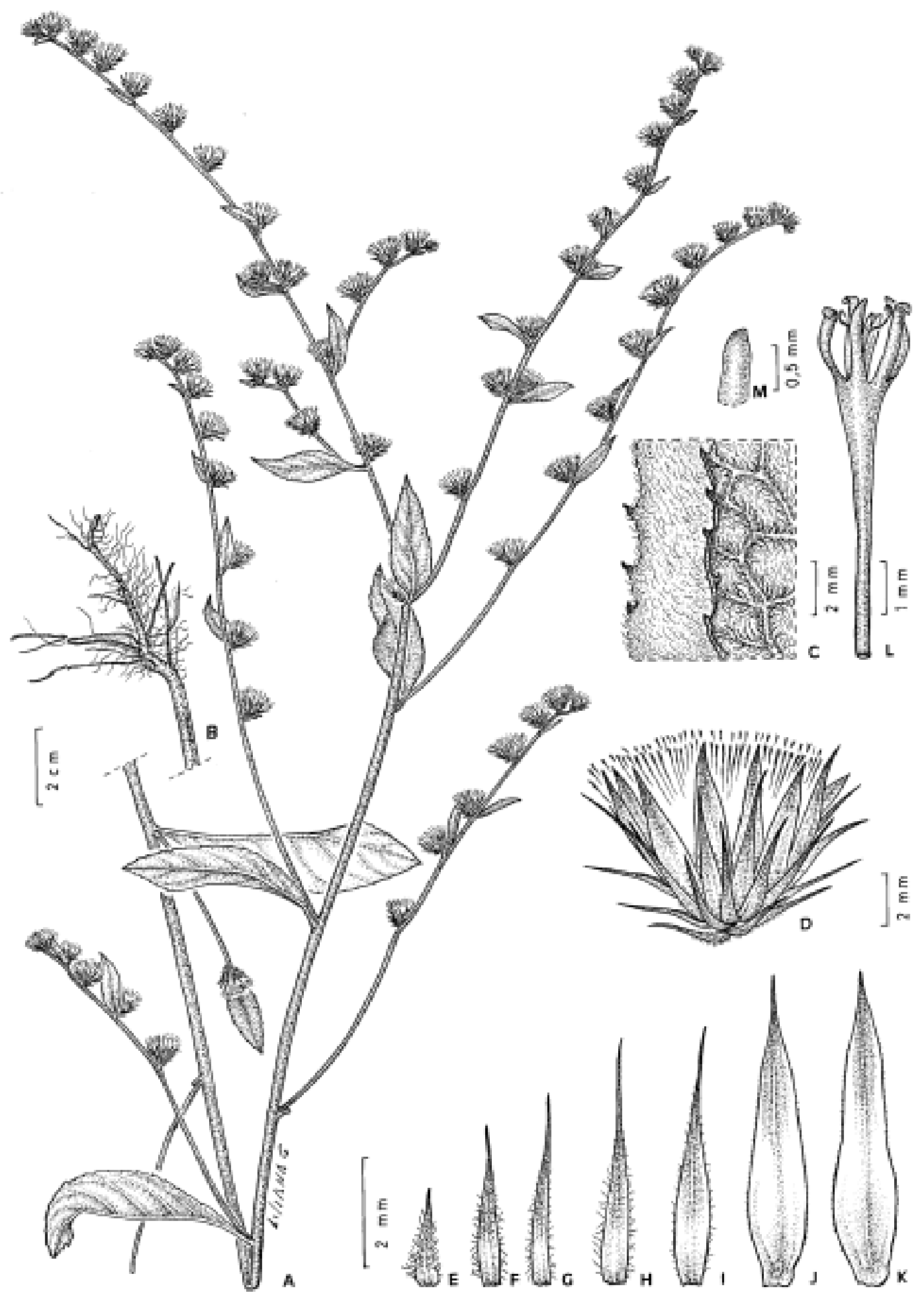

FIGURE 17. Lepidaploa remotiflora. A. Plant. B. Root. C. Margin leaf detail. D. Capitula. E-G: Outer phyllaries. G-K. Inner phyllaries. L. Floret. M. Corolla lobe detail. Source: Marques \& Dematteis (2014).

Distribution and habitat - In southern South America, the species occurs in Argentina (Corrientes, Formosa, Misiones), Brazil (Paraná and Rio Grande do Sul) and Paraguay (Amambay, Caazapá, Canindeyú, Central, Cordillera, Guiará, Itapúa, Ñeembucú, Paraguarí, San Pedro). According to Dematteis \& Cabrera (2009), in Paraguay this species is also found in Alto Paraná, Caaguazú, Concepción, Misiones and Presidente Hayes. The species can be possibly found in the Argentinian provinces of Tucumán and Salta (Marques \& Dematteis 2014). It inhabits crop fields, cerrado fields, wetland regions, forest margins and canopy (Figure 18).

Phenology - The species blooms throughout the year. 
Notes - This species can be confused with L. amambaia and L. setososquamosa, which also occur in southern South America, but $L$. remotiflora can be differentiated from both species by its acute leaf apex, eucamptodromousreticulodromous venation, inner phyllaries with acute apex and the presence of glandular trichomes on the style branches and corolla lobes. See comments under L. amambaia.

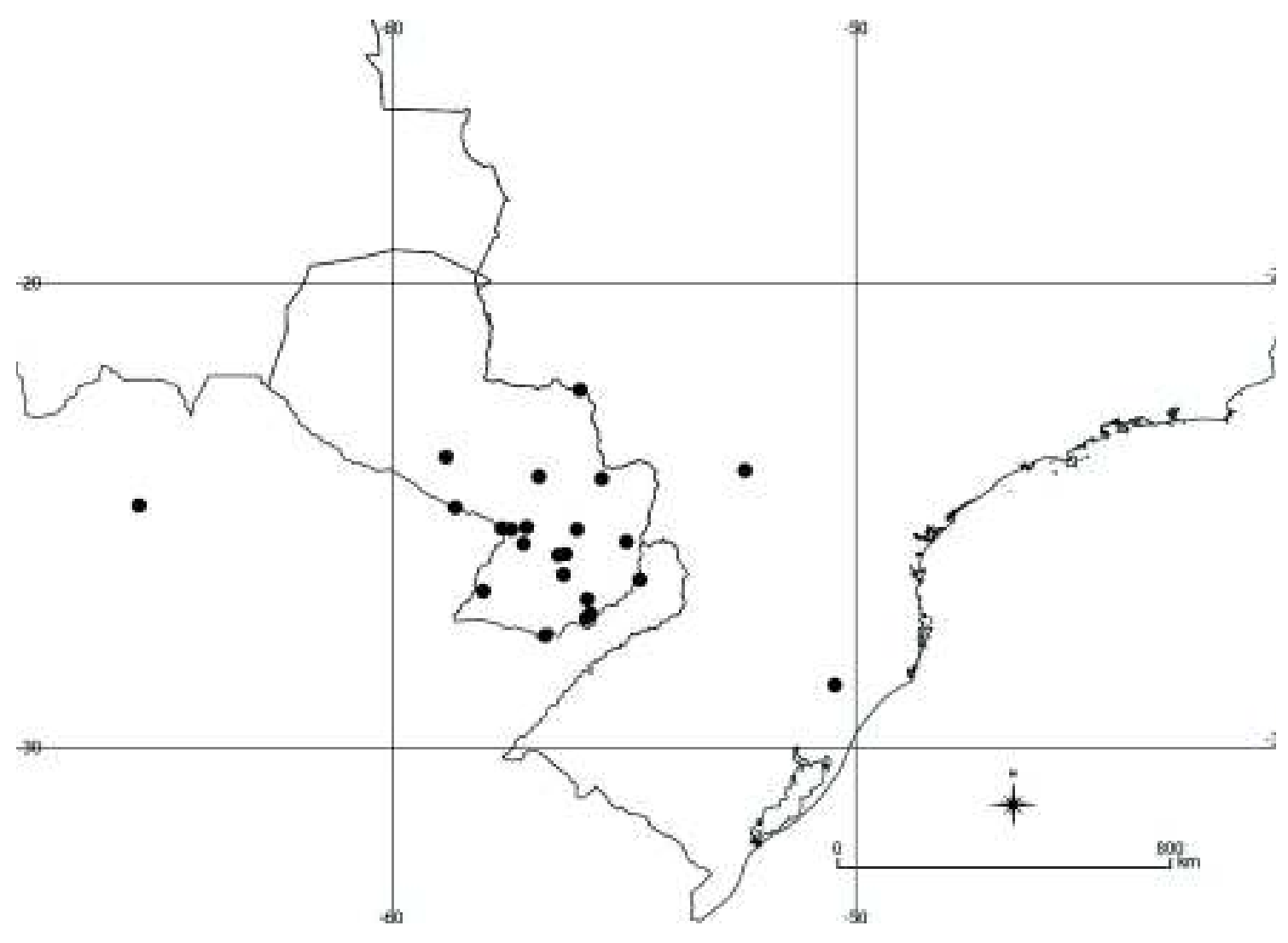

FIGURE 18. Geographical distribution of L. remotiflora (circle) in Cone Sur.

11. Lepidaploa salzmannii (DC.) Robinson (1990: 492). Vernonia salzmannii Candolle (1836: 55).

Type:-BRAZIL. Bahia, "'in umbrosis, ubi semel a me lecta", 1830, P. Salzmann 47 (holotype G-DC! [online image!]). Figure 19.

Shrubs $0.9 \mathrm{~m}$ tall; branches sericeous, slightly ribbed. Leaves distichous, cauline, internodes $2.8-3.8 \mathrm{~cm}$ long, petioles 3-4 mm long, blade 7.5-10.5 × 1.9-2.2 cm, membranaceous, smooth, lanceolate, apex acute, margins entire, base cuneate, adaxial surfaces glabrescent, abaxial surfaces tomentose; venation eucamptodromous. Capitulescence seriate-cymose with capitula sessile, 12-13.2 cm long, axis sericeous, gray. Involucre campanulate, 6-7 mm in diam., phyllaries 5-6-seriate, brown, membranaceous, glabrescent, outer elliptic-lanceolate, apex apiculate, inner lanceolate, apex slightly apiculate. Florets 19-21, corolla lilac, tube 4-5 mm long, glabrous, lobes 1.6-2.5 mm long, lanceolate, apex setose-glandular; apical anther appendages obovate, base slightly sagittate; basal stylar node enlarged. Cypsela turbinate to obconic, 1.5-2 mm long, setose-glandular, idioblasts present; carpopodium anullar. Pappus beige.

Selected specimens examined —BRASIL. Paraná: Tomazina, Guaviroval, 02 September 1998, G. Hatschbach 68293 (CTES). Antonina, Reserva Biológica de Sapintanduva, 15 May 1981 G. Hatschbach 43889 (MBM).

Distribution and habitat - In the study region, Lepidaploa salzmannii was found only in the state of Parana, Brazil. According to Dematteis \& Cabrera (2009), this species also occurs in the department of Alto Paraguay, Paraguay. It grows on forest margins or under canopy in the Atlantic Rainforest (Figure 20).

Phenology - The species was found in flower in May and September.

Notes-This species is morphologically similar to L. chamissonis because of the following common characters: leaves lanceolate, petioles 3-4 mm long, cypselae setose-glandular with idioblasts. See comments under $L$. chamissonis. 


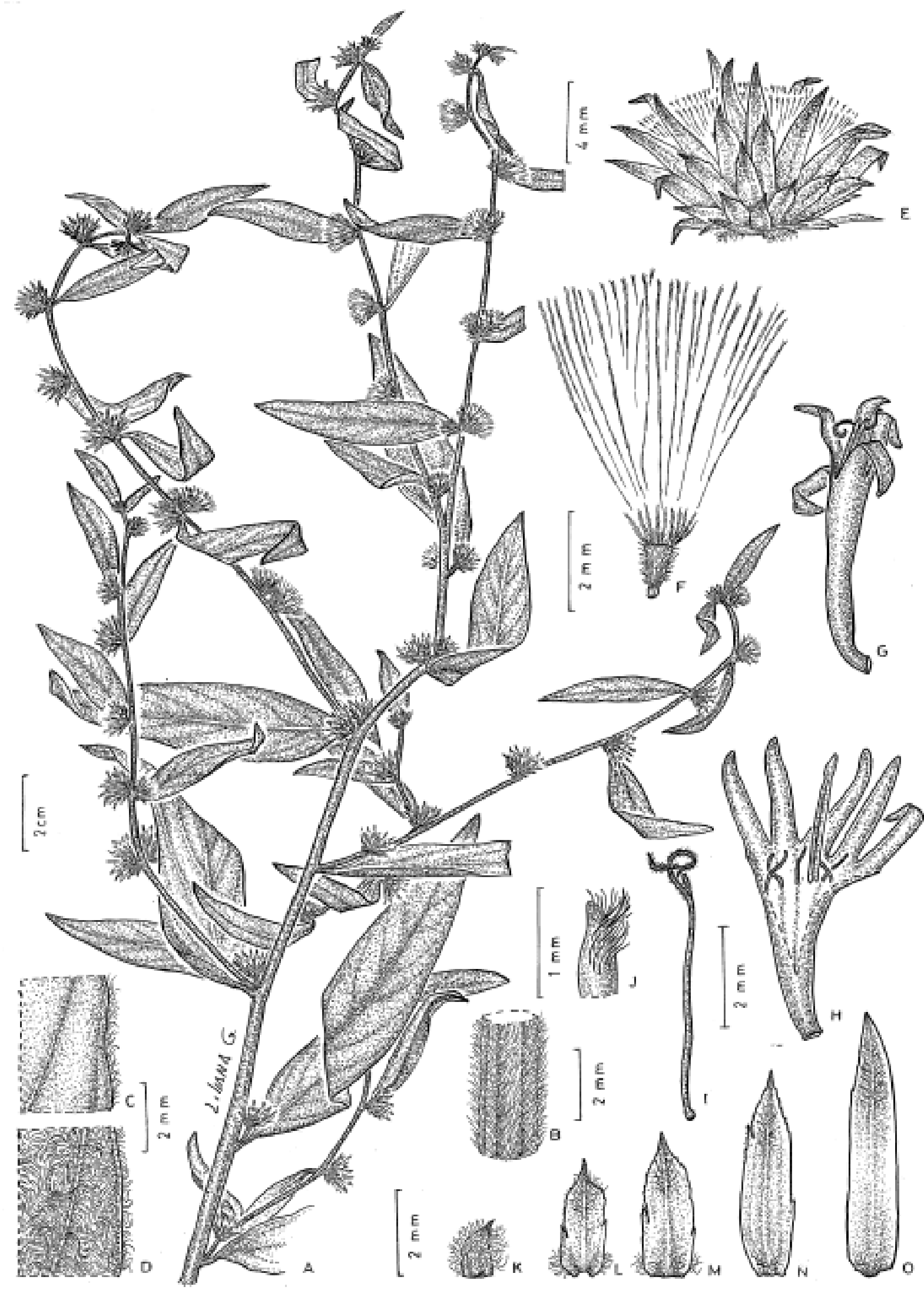

FIGURE 19. Lepidaploa salzmannii. A. Plant. B. Stem detail. C. Abaxial leaf surface detail. D. Abaxial leaf surface detail. E. Capitula. F. Cypsela and pappus. G. Floret. H. Floret dissected. I. Style. J. Corolla lobe detail. K-L. Outer phyllaries. M-O. Inner phyllaries. 


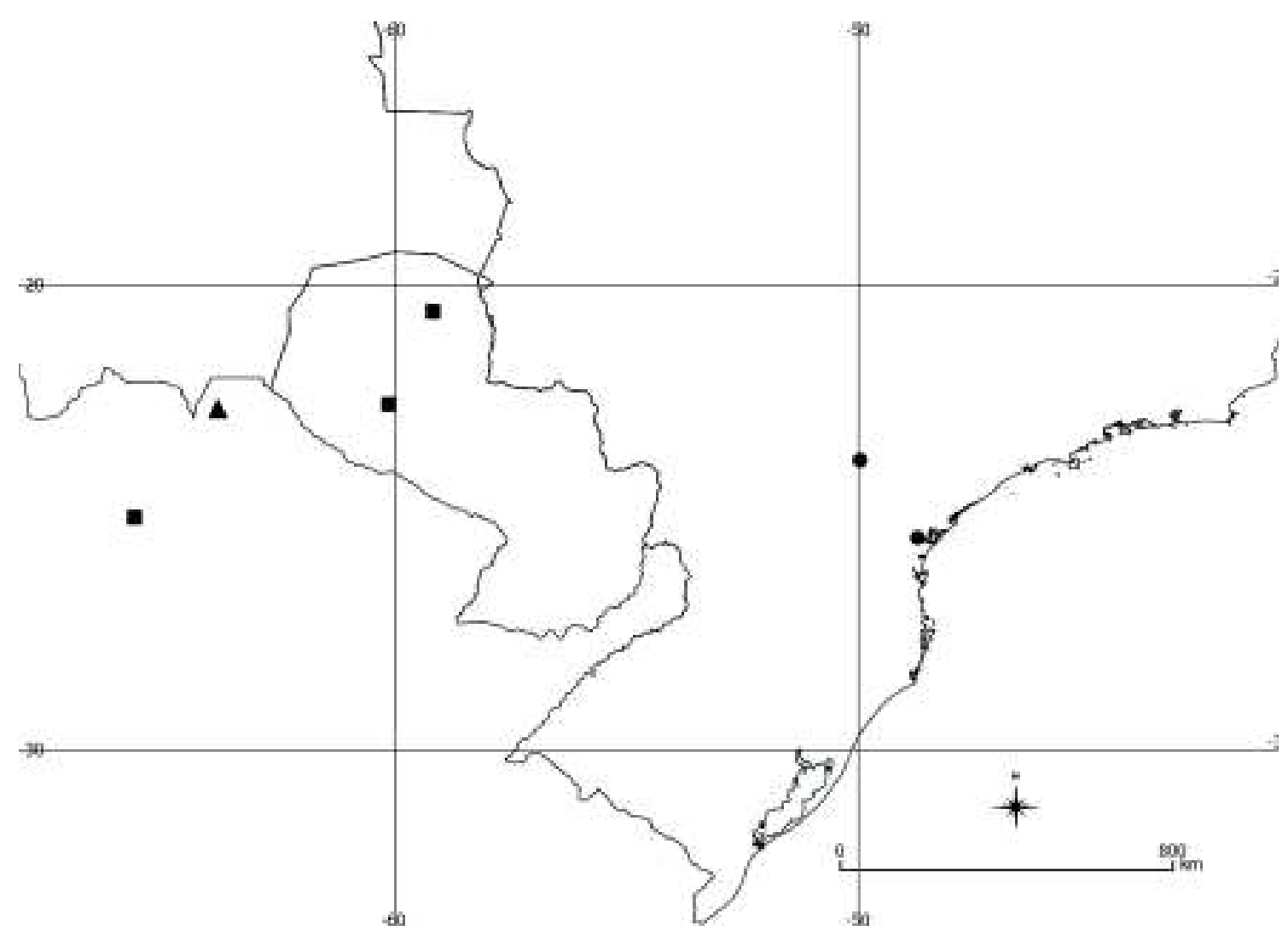

FIGURE 20. Geographical distribution of L. salzmannii (circle), L. setososquamosa (square) and L. tarijensis (triangle) in Cone Sur.

12. Lepidaploa setososquamosa (Hieron.) Angulo \& Dematteis (2012: 271). Vernonia setososquamosa Hieronymus (1897: 864).

Type:-ARGENTINA. Salta province, Tarija department, Nogalitos, February 1873, P. G. Lorentz \& G. H. E. W. Hieronymus 1205

(lectotype COND! [photo!], designated by Cristóbal \& Dematteis (2003: 47)). Figure 21.

Subshrubs 0.4-0.6 m tall; branches setose. Leaves distichous, cauline, internodes 1.1-2.1 cm long, sessile, blade 2.510.2×0.6-3.2 cm, membranaceous, smooth, oval, ovate-lanceolate, apex apiculate, margins denticulate, base attenuate, both surfaces setulose; venation eucamptodromous-brochidodromous. Capitulescence seriate-cymose or paniculiform with capitula sessile, 10-20 cm long, axis densely velutinous, brown to green-yellowish. Involucre campanulate, 12-14 $\mathrm{mm}$ in diam., phyllaries 5-6-seriate, brown or greenish with blackened apex, scarious to membranaceous, tomentose, outer linear-lanceolate, apex aristate, inner elliptic-lanceolate, apex aristate. Florets 23-25, corolla violet, tube 4-5 $\mathrm{mm}$ long, glabrous, lobes 3.5-5 mm long, lanceolate, apex setose; apical anther appendages acute, base slightly obtuse; basal stylar node enlarged. Cypsela turbinate, $1.55-1.7 \mathrm{~mm}$ long, sericeous-glandular, idioblasts present; carpopodium anullar. Pappus white.

Selected specimens examined - ARGENTINA. Salta: Rosario de Lerma, Dique Las Lomitas, Ribera Oeste, 09 February 1997 L.J. Novara 10877 (CTES). PARAGUAY. Alto Paraguay: Camino Gabino Mendoza a General Garay, 31 March 1995, R. Degen 3298 (FCQ). Boquerón: Parque Valle Natural, 12 km de Filadelfia, 28 February 1991, $R$. Vanni 2476 (CTES).

Distribution and habitat - In southern South America the species is distributed in Argentina (Salta) and Paraguay (Alto Paraguay and Boquerón). In the study region the species inhabits fields on sandy soils in the Cerrado (Figure 20).

Phenology - Collected with flowers from November to March.

Notes - This species is morphologically similar to L. remotiflora and L. amambaia, which also occur in southern South America. However, L. setososquamosa has a more restricted distribution than L. remotiflora and can be differentiated from the latter by its leaves with apiculate apex, eucamptodromous-brochidodromous venation, inner phyllaries with apiculate apex and absence of glandular trichomes on the style branches and corolla lobes. In turn, $L$. setossosquamosa is distinguished from L. amambaia by its heads with 23-25 florets, sessile leaves 12-14 mm long, and sericeo-glandular cypselae. See comments under L. amambaia and L. remotiflora. 


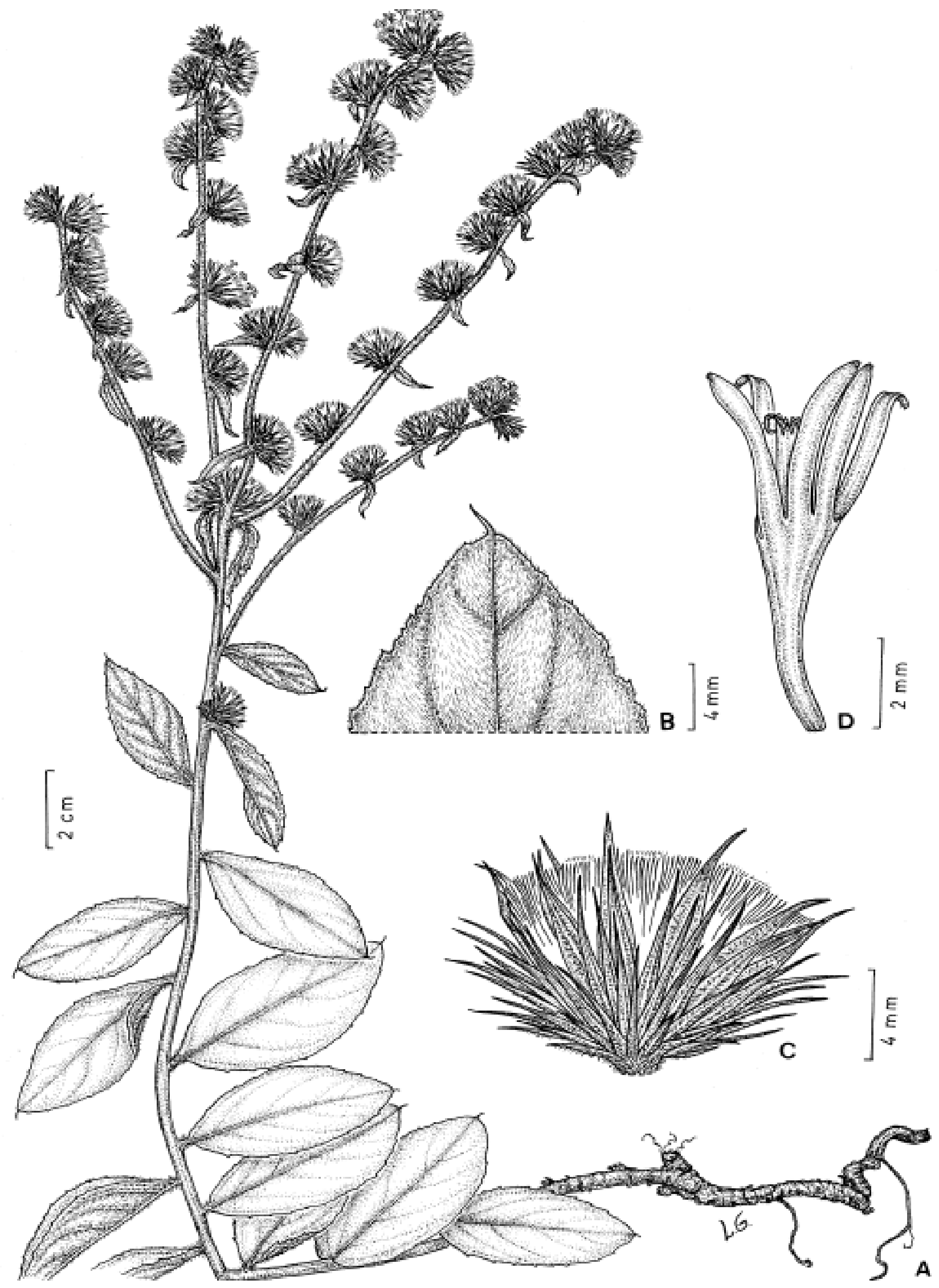

FIGURE 21. Lepidaploa setososquamosa. A. Plant. B. Abaxial leaf surface detail. C. Capitula. D. Floret. Source: Marques \& Dematteis (2014). 
13. Lepidaploa tarijensis (Griseb.) Robinson (1990: 495). Vernonia sericea var. tarijensis Grisebach (1879: 163). Type:-BOLIVIA. Bei Carapari, 19 Juny 1873, P. G. Lorentz 634 (syntypes COND! GOET! [photo!]). Figure 22.

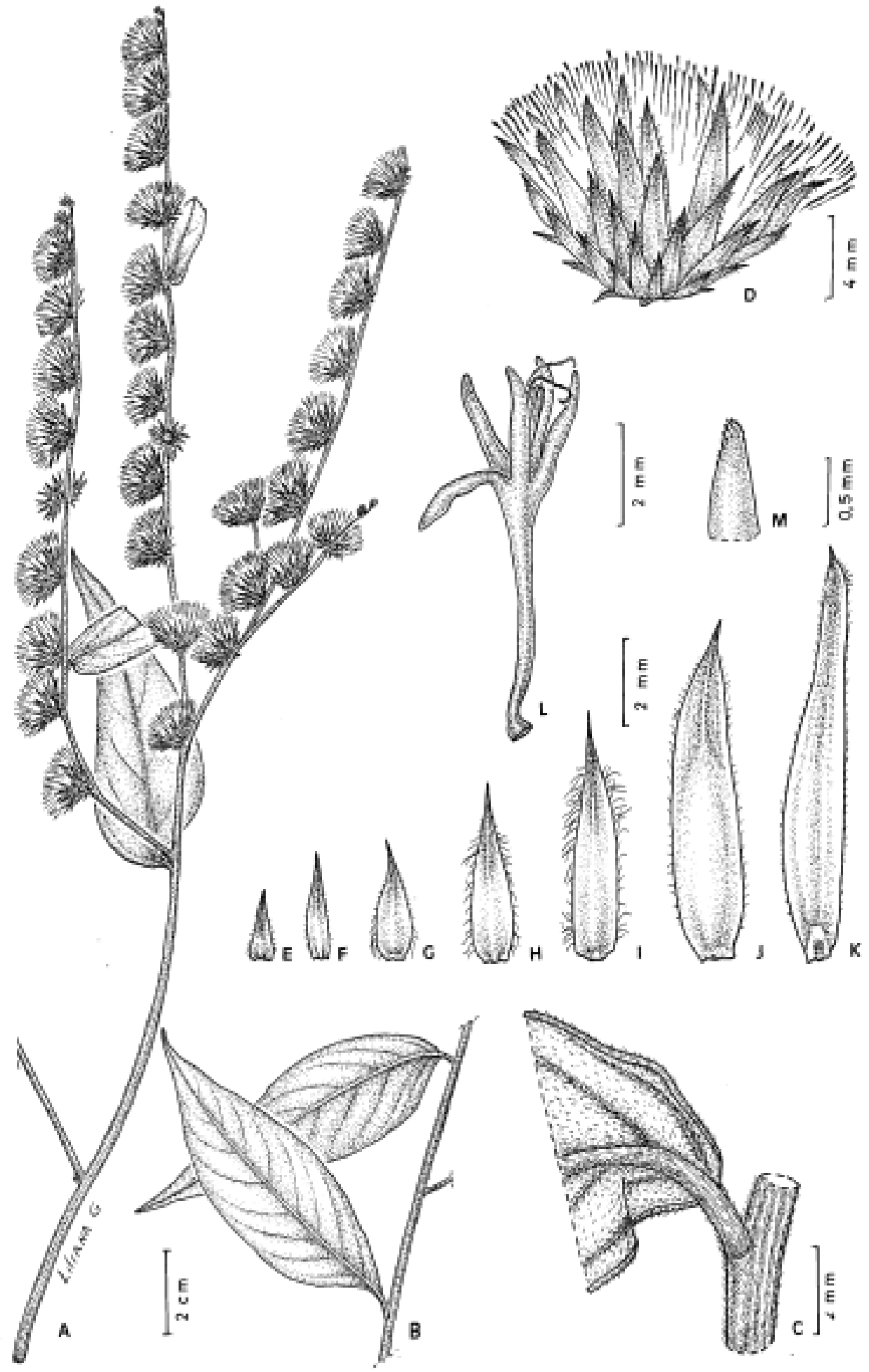

FIGURE 22. Lepidaploa tarijensis. A. Plant. B. Stem and leaf. C. Stem and leaf detail. D. Capitula. E-G. Outer phyllaries. H-K. Inner Phyllaries. L. Floret. M. Corolla lobe detail. Source: Marques \& Dematteis (2014).

Clambering shrubs 1-2 m tall.; branches pubescent. Leaves distichous, cauline, internode $2.2-3.8 \mathrm{~cm}$ long, petioles 3-5 mm long, blade 6.4-8.4 × 1.7-2.7 cm, membranaceous, slightly rugose, ovate-lanceolate, lanceolate, apex acute, margins entire, sometimes sinuate, base attenuate, adaxial surfaces glabrous, abaxial surface pubescent or glabrous; venation camptodromous-eucamptodromous. Capitulescence seriate-cymose with capitula sessile, $3-5.6 \mathrm{~cm}$ long, axis densely sericeous, brown to yellowish. Involucre widely campanulate, $8-10 \mathrm{~mm}$ in diam., phyllaries 5-8-seriate, yellowish, scarious, glabrous or pubescent on margins, outer oval-lanceolate, apex apiculate, inner elliptic-lanceolate, 
apex acute or apiculate. Florets 24-27, corolla white or pinkish, tube 4-4.2 mm long, glabrous, lobes 2-2.5 mm long, lanceolate, apex setose; apical anther appendages acute or obtuse, base obtuse; basal stylar node enlarged. Cypsela turbinate, 2-2.3 mm long, sericeous; carpopodium anullar. Pappus white.

Selected specimens examined-ARGENTINA. Salta: General San Martín, camino al Dique Itiyuro, $2 \mathrm{~km}$ de la Ruta 34, 22.IX.1997, M. Dematteis 839 (CTES).

Distribution and habitat - In the study region Lepidaploa tarijensis can be found only in the extreme north of Salta, Argentina. In Salta, the species was found only in the department of General José de San Martín. This species grows on the edges of the North-Central Humid Andes (Figure 20).

Phenology - Collected with flowers from May to August.

Notes - Lepidaploa tarijensis is similar to L. novarae. See comments under L. novarae. In summary, L. tarijensis can be differentiated from the other species of southern South America by the following combination of characters: clambering shrubs, pappus white, involucre $8-10 \mathrm{~mm}$ long, glandular trichomes absent on the corolla lobes, and cypselae without idioblasts.

\section{Acknowledgments}

We are grateful to Mirtha Liliana Gómez for the line drawing of the species and Ercilia María Sara Moreno for helpful suggestions and comments on the manuscript. This work was supported by grants from the Consejo Nacional de Investigaciones Científicas y Técnicas (CONICET).

\section{References}

Anderberg, A.A., Baldwin, B.G., Bayer, R.G., Breitwieser, J., Jeffrey, C., Dillon, M.O., Eldenäs, P., Funk, V., Garcia-Jacas, N., Hind, D.J.N., Karis, P.O., Lack, H.W., Nesom, G.L., Nordenstam, B., Oberprieler, C., Panero, J.L., Puttock, C., Robinson, H., Stuessy, T.F., Susanna, A.. Urtubey, E., Vogt, R., Ward, J. \& Watson, L.E (2007) Compositae. In: Kadereit, J.W. \& Jeffrey, C. (Eds.) Kubitzki’s The families and genera of Vascular Plants. Vol. 8. Springer, Berlin \& Heidelberg, pp. 61-588. https://doi.org/10.1007/978-3-540-31051-8_7

Angulo, M.B., Vega, A.J. \& Dematteis, M. (2012) Nuevas combinaciones en los géneros sudamericanos Lepidaploa y Lessingianthus (Vernonieae, Asteraceae). Gayana Botánica 69 (2): 267-274.

https://doi.org/10.4067/S0717-66432012000200006

Baker, J.G. (1873) Compositae I. Vernoniaceae. In: Martius, C.F.P. \& Eichler, A.G. (Eds.) Flora brasiliensis. Vol. 6. Pt. 2. Fleischer, Leipzig, pp. 1-179.

Cabrera, A.L. \& Klein, R.M. (1980) Fasciculo Compostas 3: Tribo Vernonieae. In: Reitz, R. (Ed.) Flora Ilustrada Catarinense. Itajaí, pp. 227-408.

Cabrera, A.L. (1997) Una nueva especie de Vernonia (Compositae) del este de Salta (Argentina). Hickenia 2 (54): $255-256$.

Candolle, A.P. de (1836) Prodromus systematis naturalis regni vegetabilis. Vol. 5. Treuttel \& Würtz, Paris, 706 pp.

Cassini, A.H.G. (1817) Aperçu des genres nouveaux formés par M. Henri Cassini dans la familla des Synanthérés. Quatrième fascicule. Bulletin des Sciences de La Sociéte Philomatique de Paris 1817: 66-70.

Cassini, A.H.G (1825) Oliganthe, Oliganthes. In: Cuvier, F.G. (Ed.) Dictionnaire des Sciences Naturelles. Vol. 36. F.G. Levrault, Strasbourg \& Paris, \& Le Normant, Paris, pp. 18-20.

Cristóbal, C.L. \& Dematteis, M. (2003) Asteraceae. XVIII. Tribu I. Vernonieae. In: Hunziker, A.T. (Ed.) Flora Fanerogámica Argentina. Vol. 83. Museo Botánico de Córdoba, Argentina, pp. 3-53.

Dematteis, M. \& Cabrera, A.L. (2009) Vernonieae. In: Ramella, L. \& Perret, P. (Eds.) Flora del Paraguay. Vol. 39: Compositae IV. Conservatoire et Jardin botaniques de la Ville de Genève, Genève, pp. 65-298.

Dematteis, M. \& Almeida, G. (2015) Lepidaploa. In: Lista de Espécies da Flora do Brasil. Jardim Botânico do Rio de Janeiro. Available from: http://floradobrasil.jbrj.gov.br/jabot/floradobrasil/FB16164. (accessed 1 September 2016)

Funk, V.A., Susanna, A., Stuessy, T.F. \& Bayer, R.J. (2009) Systematics, Evolution, and Biogeography of Compositae. Smithsonian Institution, Washington, $965 \mathrm{pp}$.

Gardner, G. (1845) Contributions towards a Flora of Brazil, being the distinctive characters of a century of new species of plants from the Organ Mountains. London Journal of Botany 4: 97-136.

Gardner, G. (1846) Contributions towards a Flora of Brazil, being the distinctive characters of some new species of Compositae, belonging 
to the tribe Vernoniaceae. London Journal of Botany 5: 209-242.

Grisebach, A.H.R. (1879) Symbolae ad Floram Argentinam. Abhandlungen der Königlichen Gesellschaft der Wissenschaften zu Göttingen 24: $1-345$.

Hind, N. (2011) An annotated preliminary Checklist of the Compositae of Bolivia. Version 2. Richmond, Royal Botanical Gardens, Kew, $750 \mathrm{pp}$.

Hieronymus, G.H.E.W. (1897) Erster Beitrag zur Kenntnis der Siphonogamenflora der Argentina und der angrenzenden Länder, besonders von Uruguay, Paraguay, Brasilien und Bolivien. Botanische Jahrbücher für Systematik, Pflanzengeschichte und Pflanzengeographie 22: $672-798$.

Keeley, S.C. \& Robinson, H. (2009) Vernonieae. In: Funk, V.A., Susanna, A., Stuessy, T.F. \& Bayer, R.J. (Eds.) Systematics, evolution and biogeography of Compositae. IAPT, Vienna, pp. 439-469.

Lessing, C.F. (1829) Synanthereis Herbarii Regii Berolinensis dissertatio prima. Linnaea 4: 289-356.

Marques, D. \& Dematteis, M. (2014) Lepidaploa (Cass.) Cass. In: Zuloaga, F.O., Belgrano, M.J. \& Anton, A.M. (Eds.) Flora Argentina, Flora Vascular de la República Argentina. Vol. 7. Dicotyledoneae, Asteraceae: Senecio a Vernonieae. IBODA CONICET, Argentina, pp. 243-249.

Moreira-Muñoz, A. (2011) Plant Geography of Chile. Springer, New York, 320 pp. https://doi.org/10.1007/978-90-481-8748-5

Myers, N., Mittermeier, R.A., Mittermeier, C.G., Fonseca, G.A.B. \& Kent, J. (2000) Biodiversity hotspots for conservation priorities. Nature 403: 853-858. https://doi.org/10.1038/35002501

Newton, A.C. \& Tejedor, N. (2011) Principles and Practice of Forest Landscape Restoration. IUCN, Gland, Switzerland, 383 pp.

Panero, J.L., Freire, S.E., Espinar, L.A., Crozier, B.S., Barboza, G.E. \& Cantero, J.J. (2014) Resolution of deep nodes yields an improved backbone phylogeny and a new basal lineage to study early evolution of Asteraceae. Molecular Phylogenetics and Evolution 80: 43-53. https://doi.org/10.1016/j.ympev.2014.07.012

Pruski, L.B. (1998) Compositae of the Guayana Highland XIII. New combinations in Conyza (Astereae), Praxelis (Eupatorieae), and Riencourtia (Heliantheae) based on names proposed by L.C.M. Richard. Britonnia 50: 473-482. https://doi.org/10.2307/2807757

Radford, A. (1986) Fundamentals of plant systematics. Harper \& Row, New York, 498 pp.

Redonda-Martínez, R. \& Villaseñor, J.L. (2011) El género Lepidaploa (Familia Asteraceae, Tribu Vernonieae) en México. Revista Mexicana de Biodiversidad 82: 782-797.

Richard, L.C.M. (1792) Catalogus Plantarum, ad Societatem, ineunte anno 1792, e Cayenna missarum a Domino le Blond. Actes de la Société d'Histoire Naturelle de Paris 1: 105-114.

Robinson, H. (1990) Studies in the Lepidaploa complex (Vernonieae: Asteraceae). VII. The genus Lepidaploa. Proceedings of the Biological Society of Washington 103 (2): 464-498.

Robinson, H. (1994) New combinations in American Vernonieae (Asteraceae). Phytologia 76 (1): $27-29$.

Robinson, H. (1995) New combination and new species in American Vernonieae (Asteraceae). Phytologia 78 (5): $384-399$. https://doi.org/10.5962/bhl.part.10065

Robinson, H. (1998) Two new species of Lepidaploa (Vernonieae: Asteraceae). Phytologia 84 (1): 40-42. https://doi.org/10.5962/bhl.part.17403

Robinson, H. (1999) Generic and subtribal classification of American Vernonieae. Smithsonian Contributions to Botany 89: 1-116. https://doi.org/10.5479/si.0081024X.89

Robinson, H., Bohlmann, F. \& King, R.M. (1980) Chemosystematic notes on the Asteraceae. III. Natural subdivisions of the Vernonieae. Phytologia 46: 421-436. https://doi.org/10.5962/bhl.part.14735

Zuloaga, F.O., Morrone, O. \& Belgrano, M.J. (2008) Catálogo de Plantas Vasculares del Cono Sur, vol. 1. Monographs in Systematic Botany from the Missouri Botanical Garden 107: 1-3348. 
Appendix I. Collectors List

Abrão, H.R.S. 84 (3); Adenesky, E. FURB 4542 (3); Aguayo, A. 526 (3); Ahumada, O. 8177 (7), 8365 (7); Angulo, M.B. 20 (10); Arbo, M.M. 5933 (3), 8866 (10), 8993 (12), 9227 (10); Arzivenco, L. 44336 (8); 48496 (3); Azevedo, T.I.N. 530 (3); Baptista, L. ICN 25533 (3); Barbero, A. 313 (10); Barbosa, E. 700 (6), 1012 (2), 3674 (1); Barboza, G. 503 (10); Basualdo, I. 2224 (10), 2544(3), 3500 (3); Bertoni, M.S. 2879 (3), 3677 (3); Bianek, A.E. 150 (4); Bordas, E. 1014 (10), 1251 (10), 1593 (10), 1835 (10), 3612 (10); Bordón, A.O. 230 (4), 340(4), 372 (4), 644 (4); Bresolin, A. 313 (6); Broto M.L. 1723(6); Bueno, O. 1032 (3); 1200 (8); Cabral, E. 348 (9); Camargo, O. PACA 63650 (3), 1471 (3); Carnevali, R. 507 (3), 5471 (10), 5638 (10), 5639 (10); Carneiro, J. MBM 164945 (4), 482 (3), 1432 (3); Carriz, B. RB 57451 (4); Caxambú, M.G. 518 (3); Cervi, A. 526 (3), Cordeiro, J. 1554 (6); Correa, M.N. 7909 (3), 7949 (3); Cowan, C.P. 4157 (10); Cristóbal, C.L. 1744 (3); Crovetto, M. 237 (3), 679 (4), 11357 (3); Degen, R. 483 (10), 636 (10), 1488 (3), 1606 (3), 3298 (12); Deble, L.P. 12020 (9); Dematteis, M. 273 (10), 311 (10), 477 (10), 514 (10), 839 (13), 867 (1), 2646 (10), 3047 (9), 3336 (1), 4139 (9); Dreveck, S. 1826 (8), 2315 (4); Duarte, A.P. 5269 (3); Dziewa, A. 66 (6), 85 (6); Egea, J. 1213 (10); Eggers, L. ICN 84025 (4); Falkenberg, D.B. 2530 (6), 2604 (6), 2612 (6), 4364 (6), 6127 (4); Ferrari, M.V. 1202 (3); Ferrucci, M.S. 2821 (10); Fleigi, M. 38 (8); Fravo, A. 13 (4); Funez, L.A. 1928 (4); Gaelzer, M.B. 65 (7), 82 (3), 99 (8), 1979 (3); Gasper, A.L. 1418 (8), $1495(8), 1574$ (8), 1606 (8); Geraldino, H.C.L. 104 (3); González, F. 256 (3), 1323 (10); Grazziotin, G. 260 (3); Guimarães, T.B. 530 (4), 544 (4); Hagelund, K. 1045 (3), 3781 (3), 13118 (8); Hahn, W. 2457 (10); Hatschbach, G. 4032 (3), 6144 (6), 7268 (3), 7528 (4), 8845 (10), 8848 (4),14523 (6), 16529 (3), 24258 (3), 29372 (4), 32304 (3), 41438 (8), 43889 (11), 48084 (3), 49535 (6), 51930 (4), 54444 (6), 55471 (5) 61081 (3), 68293 (11), 69264 (3), 71841 (4), 78291 (8), 78959 (8), 79080 (10), 79126 (4), 79137 (3), 79554 (8), 79695 (8), 79077 (8), 79109 (8), 79121 (8), 79766 (8), 79833 (8), 79945 (3); Hauman 4497 (3); Hentschel, R. ICN 157942 (4); Henz, E. PACA 27631 (3); Herrera, J. 357 (10); Hilgert, N. 425 (10); Hunziker, A.T. 5373 (4); Imaguire, N. 2789 (8); Jarenkow, J.A. 83 (3), 715 (3), 888 (3), 1689 (3), 2526 (3), 3119 (3); Jiménez, B. 1408 (3); Kell, S. 1509 (3); Keller, H.A. 280 (3), 1112 (3), 1778 (10), 2070 (10), 3106 (3), 3518 (10), 3921 (7), 4096 (10), 4268 (10), 4788 (10), 4828 (10), 5533 (3), 5590 (10), 5868 (10), 6416 (10), 6448 (9), 7036 (8), 8792 (3); Klein, R.M. 5426 (6); 5435 (3), 5446 (3), 5552 (3), 5650 (3), 5726 (3), 6639 (8), 7200 (4), 10647 (5); 10895 (5); Korte, A. 1624 (8), 1745 (8), 1851 (7), 4010 (5), 5917 (8); Krapovickas, A. 12152 (10), 12228 (10), 13086 (10), 13948 (10), 13886 (10), 13948 (10), 15932 (3), 18183 (10), 19452 (13), 24912 (10), 25011 (10), 25552 (3), 26236 (3), 28674 (9), 29153 (10), 33613 (8), 37727 (4), 38426 (4), 41886 (10), 44154 (10), 44197 (12), 44450 (10), 44612 (9), , 45131 (3), 45468 (12), 46296 (12), 47264 (13); Kummrow, R. 3077 (6); Kuniyoshi, Y.S. 4994 (6); Kurtz, F. 08 (10); Layzon, A.S. RB (650076) (4); López, M.G. 257 (10); Loureiro, M.L. 750 (6); Lurvey, E. 56514 (10); Marmoni, G.C. 410 (3); Maruñak, V. 963 (10); Mereles, F. 5040 (12), 5042 (12), 7717 (3), 8484 (10); Miranda, D. 77 (3); Molero, J. 09 (10); Mondih, C. 813 (8); Montes, J.E. 2142 (3), 15428 (3), 15837 (3); Motta, J.T. 881 (3); Nicolack, V. 133 (6); Novara, L.J. 10877 (12); Nuember, A. 48 (4); Ortíz, M. 235 (3); 423 (10); Pasini, E. 333 (8); Paul, M.R. 21 (10); Paula-Souza, J. 7260 (10); Pedersen, T.M. 15918 (8); Peña-Chocarro, M. 2210 (10), 2594 (10); Pérez, L. 442 (3); Piccinini, B. 3607 (10); Ponciano, J. MBM 78551 (3); Queiroz, M.H. 259 (6); Rambo, B. PACA 30993 (3), PACA 41850 (3), PACA 42001 (3), PACA 42105 (3), PACA 42229 (3), PACA 42361 (3), PACA 42507 (3), PACA 47236 (3), 1872 (3), 42246 (3), 42299 (3), 47924 (3); Raw 10 (3); Recalde, A. 07 (10); Reitz, R. HBR 44149 (3), 881 (6), 3973 (6), 4581 (4); 6521 (8), 6588 (8), 10614 (8), 10742 (8), 10895 (5); Ribas, O.S. 3331 (8), 6789 (8), 7222 (8), 7987 (4); Rinnert, C.H. 308 (4); Ritter, M.R. 650 (3); Rodriguez, F.M. 92 (10); Rodriguez, M. 745 (3); Rossato, M. 69 (8); Santos, P.R. MBM 330618 (3); Schinini, A.G. 2728 (4), 3035 (9), 4907 (3), 5039 (10), 5138 (13), 6799 (3), 8006 (10), 8203 (4), 11209 (10), 15251 (4), 15855 (4), 16585 (4), 16921 (4), 16950 (4), 17190 (4), 18119 (4), 1999 (4), 22903 (1), 27052 (3), 27817 (10), 28740 (3), 30441 (10), 30472 (10), 30545 (10), 31553 (10), 32688 (10), 33245 (10), 33467 (1), 36303 (1); Schmeda,G. 55 (4); Schulz, A. 16950 (4); Schwarz, G.J. 8001 (3); Schwindt, E. 745 (3); Seger, G.D. 187 (3), 214 (3), 482 (3), 609 (3); Sehnem, A. 2866 (3); Silva, F.C. 709 (6); Silva, J.M. 1354 (6), 1726 (6), 5007 (6); Silva, J.M. 5871 (3); Smith, L.B. 7605 (3), 12289 (3); Sobral, M. MBM 78288 (3), 325 (3), 8188 (3); Soria, N. 429 (10), 717 (10), 1513 (10), 1579 (3), 1599 (3), 2047 (1), 2050 (10), 3165 (10), 3244 (10), 4004 (3), 6044 (1), 6113(1); Stival-Santos, A. 785 (6), 1984 (4), 2022 (4); Rojas, T. 634 (10), 2877 (10), 13252 (10); Tomé, M.F.V. 874 (4); Torri, M.E. 26 (10), 298 (10), 306 (10); Tortosa, M. 59 (3); Tressens, M.A. 7067 (4); Tressens, S.G. 3936 (10), 5243 (10), 5623 (3), 5649 (3), 6385 (3), 6710 (10); Vadulga, E. 81 (3); Vanni, R. 445 (4), 753 (3), 766 (10), 827 (3), 910 (3), 956 (3), 1044 (9), 2476 (12), 2703 (3), 2727 (3), 4557 (10); Vera, M. 2733 (10), 3219 (12); Verdi, M. 3809 (8), 4028 (4), 4494 (4), 5499 (6), 5909 (8); Vervoorst, B. 4581 (7); Waechter, J.A. 228 (8); Wasum, R. MBM 234353 (3); 1772 (3); 2157 (3), 2481 (8); Zanin, A. 966 (8), 1023 (8), 1033 (8); Zardinini, E. 3101 (10), 3841 (10), 4287 (10), 4938 (3), 9478 (10), 9486 (10), 9585 (10), . 9801 (3), 9875 (10), 10041 (10), 10685 (10), 11111 (10), 11570 (10), 12338 (3), 13375 (10), 13467 (3), 14041 (3), 14122 (3), 14711 (3), 14884 (10), 14889 (10), 14967 (3), 26127 (10), 26212 (10), 26690 (10), 27064 (10). 